$V_{-12}$

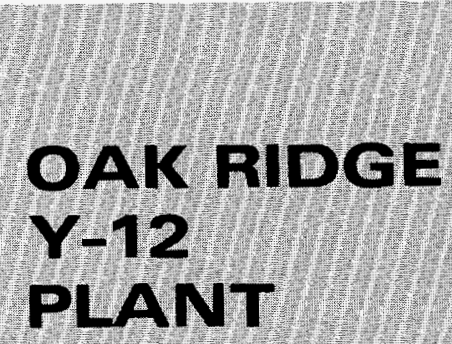

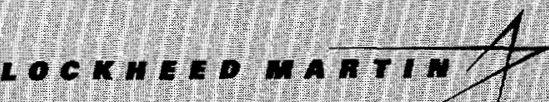

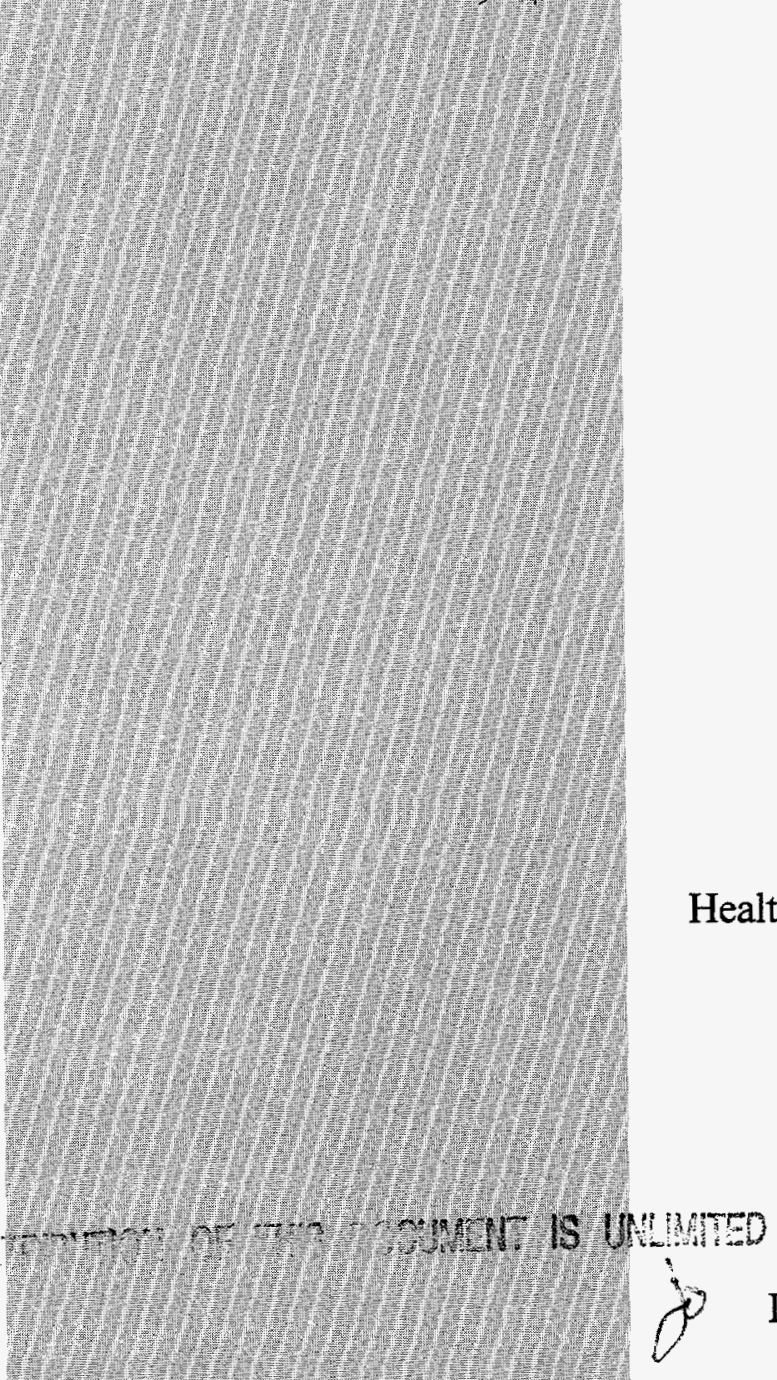

\section{MANAGED BY}

LOCKHEED MARTIN ENERGY SYSTEMS, INC.

FOR THE UNITED STATES

DEPARTMENT OF ENERGY
RECENED

DEC 201996

OSTI

\author{
OAK RIDGE Y-12 PLANT \\ GROUNDWATER PROTECTION PROGRAM \\ MANAGEMENT PLAN
}

Issue Date: June 1996

Prepared by

AJA TECHNICAL SERVICES, INC. Under Purchase Order 70Y-KDS15V

for the

Environmental Management Department

Health, Safety, Environment, and Accountability Organization

Oak Ridge Y-12 Plant

Oak Ridge, Tennessee 37831

Managed By

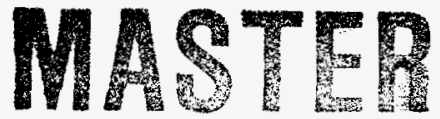




\section{DISCLAIMER}

This report was prepared as an account of work sponsored by an agency of the United States Government. Neither the United States Government nor any agency thereof, nor any of their employees, makes any warranty, express or implied, or assumes any legal liability or responsibility for the accuracy, completeness, or usefulness of any information, apparatus, product, or process disclosed, or represents that its use would not infringe privately owned rights. Reference herein to any specific commercial product, process, or service by trade name, trademark, manufacturer, or otherwise, does not necessarily constitute or imply its endorsement, recommendation, or favoring by the United States Government or any agency thereof. The views and opinions of authors expressed herein do not necessarily state or reflect those of the United States Government or any agency thereof. 


\section{DISCLAIMER}

Portions of this document may be illegible in electronic image products. Images are produced from the best available original document. 


\title{
OAK RIDGE Y-12 PLANT GROUNDWATER PROTECTION PROGRAM MANAGEMENT PLAN
}

Issue Date: June 1996

\author{
Prepared by \\ AJA TECHNICAL SERVICES, INC. \\ Under Purchase Order 70Y-KDS15V \\ for the \\ Environmental Management Department \\ Health, Safety, Environment, and Accountability Organization \\ Oak Ridge Y-12 Plant \\ Oak Ridge, Tennessee 37831
}

Managed By

LOCKHEED MARTIN ENERGY SYSTEMS, INC.

for the U.S. Department of Energy

Under Contract No. DE-AC05-84OR21400 
-

-

- 


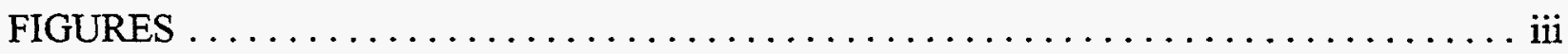

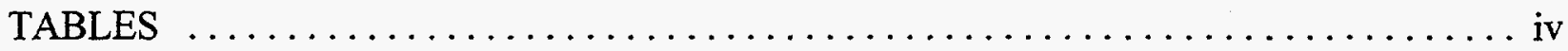

ACRONYMS AND ABBREVIATIONS $\ldots \ldots \ldots \ldots \ldots \ldots \ldots \ldots \ldots \ldots \ldots$

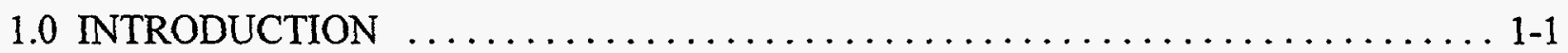

1.1 PURPOSE AND SCOPE OF THE Y-12 PLANT GWPP MANAGEMENT PLAN ............................ $1-3$

1.2 PURPOSE, POLICIES, AND OBJECTIVES OF THE Y-12 PLANT GWPP $\ldots .1-4$

1.3 HISTORY OF THE Y-12 PLANT GWPP .................... $1-5$

2.0 APPLICABLE REGULATIONS, REQUIREMENTS, AND GUIDANCE FOR

GROUNDWATER MONITORING $\ldots \ldots \ldots \ldots \ldots \ldots \ldots \ldots \ldots \ldots \ldots \ldots .2-1$

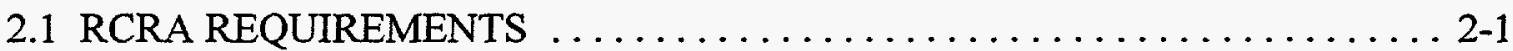

2.1 .1 RCRA TSD Facilities ............................ 2-2

2.1.1.1 Interim Status TSD Facilities $\ldots \ldots \ldots \ldots \ldots \ldots \ldots \ldots .2-2$

2.1.1.2 Permitted TSD Facilities ..................... 2-3

2.1.2 Underground Storage Tanks .......................... 2-5

2.1.3 RCRA Solid Waste Management Units . . . . . . . . . . . . . . . 2

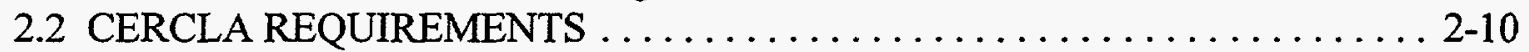

2.3 NONHAZARDOUS SOLID WASTE DISPOSAL FACILITIES $\ldots \ldots \ldots, 2-10$

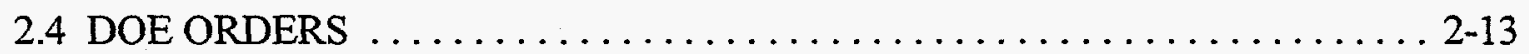

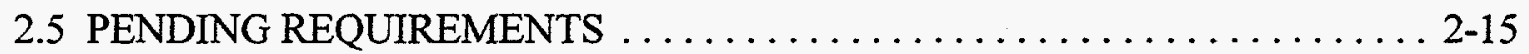

2.6 TECHNICAL GUIDANCE AND OTHER RELEVANT REQUIREMENTS . . 2-16

$3.0 \mathrm{Y}-12$ PLANT GWPP MONITORING STRATEGY $\ldots \ldots \ldots \ldots \ldots \ldots \ldots \ldots \ldots \ldots \ldots \ldots$

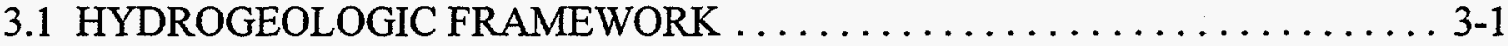

3.1.1 Site Geology ................................ 3-1

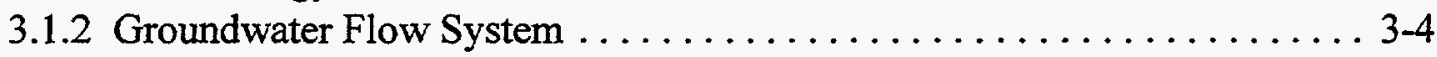

3.2 MONITORING PROGRAMS AND APPROACH $\ldots \ldots \ldots \ldots \ldots \ldots \ldots, 3-5$

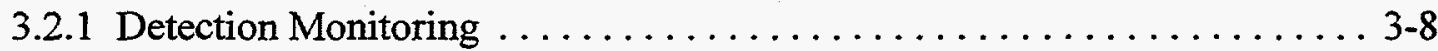

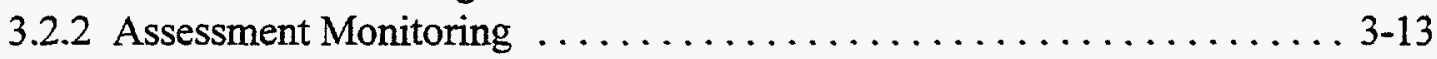

3.2.3 DOE Order 5400.1 Surveillance Monitoring .............. 3-17

3.2.4 DOE Order 5400.1 Exit Pathway and Perimeter Monitoring ........ 3-17

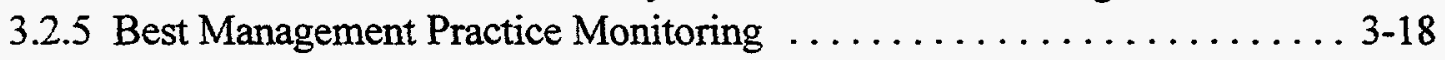

3.2.6 CERCLA Programs . ........................... 3-18 
CONTENTS (cont'd)

4.0 Y-12 PLANT GWPP ORGANIZATION, ROLES, AND RESPONSIBILITIES . . . . . 4-1

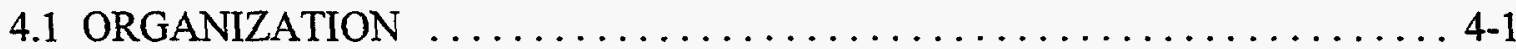

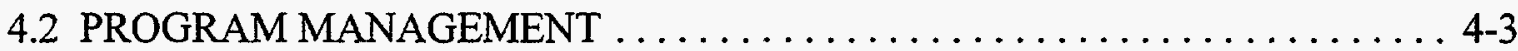

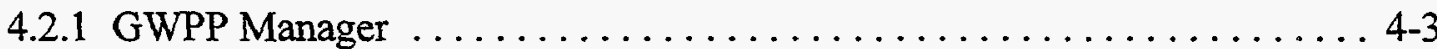

4.2.2 GWPP Technical Manager ......................... 4-5

4.2.3 GWPP Sampling and Analysis Coordinator $\ldots \ldots \ldots \ldots \ldots \ldots \ldots .5$

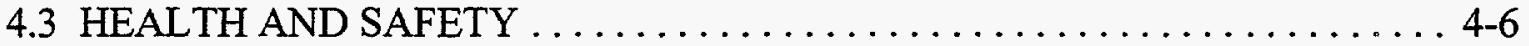

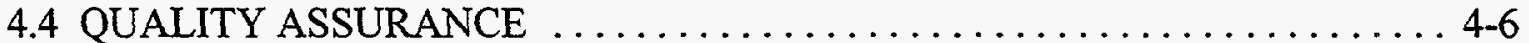

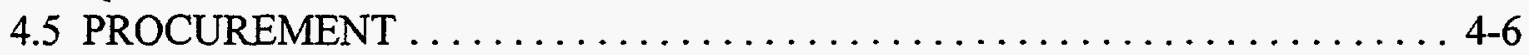

4.6 ENGINEERING AND WELL INSTALLATION $\ldots \ldots \ldots \ldots \ldots \ldots \ldots .4,7$

4.7 SAMPLING AND ANALYSIS $\ldots \ldots \ldots \ldots \ldots \ldots \ldots \ldots \ldots \ldots \ldots, 4,7$

4.8 DATA MANAGEMENT $\ldots \ldots \ldots \ldots \ldots \ldots \ldots \ldots \ldots \ldots \ldots \ldots . . \ldots \ldots$

4.9 DATA ANALYSIS, DATA VALIDATION, AND EVALUATION $\ldots \ldots \ldots 4-9$

4.10 RECORD KEEPING AND DOCUMENT CONTROL . . . . . . . . . . . . 4-9

4.11 HYDROGEOLOGICAL INTERPRETATION $\ldots \ldots \ldots \ldots \ldots \ldots \ldots \ldots, 4-10$

4.12 ENVIRONMENTAL RESTORATION PROGRAM $\ldots \ldots \ldots \ldots \ldots \ldots, 4-10$

4.13 ENERGY SYSTEMS GROUNDWATER PROGRAM OFFICE ........ 4-11

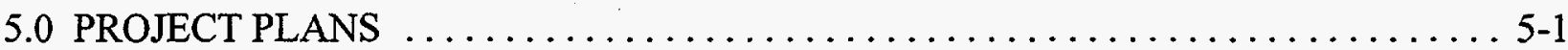

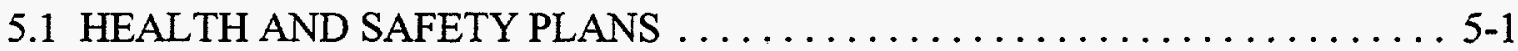

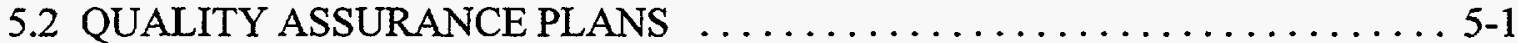

5.3 GROUNDWATER MONITORING WELL INSTALLATION PLAN $\ldots \ldots \ldots .5-2$

5.4 SAMPLING AND ANALYSIS PLAN $\ldots \ldots \ldots \ldots \ldots \ldots \ldots \ldots \ldots \ldots, 5-3$

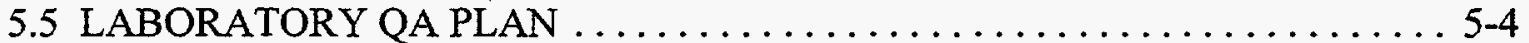

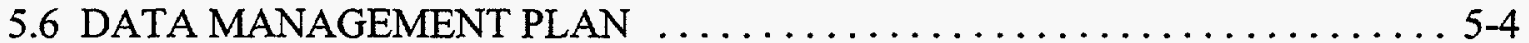

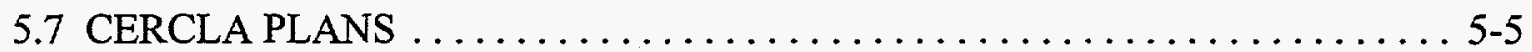

5.8 WELL PLUGGING AND ABANDONMENT PLAN $\ldots \ldots \ldots \ldots \ldots \ldots \ldots 5-5$

5.9 WELL INSPECTION AND MAINTENANCE PLAN $\ldots \ldots \ldots \ldots \ldots \ldots .5-6$

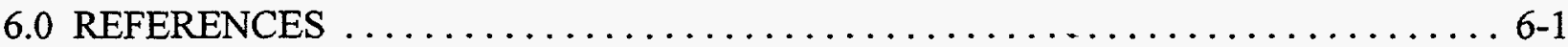

\section{APPENDICES}

A ENERGY SYSTEMS POLICY PROCEDURES ESS-EP-101 "ENVIRONMENTAL PROTECTION PROGRAM" AND ESS-EP-134 "GROUNDWATER PROTECTION PROGRAM"

B GUIDANCE DOCUMENTS 


\section{FIGURES}

Page

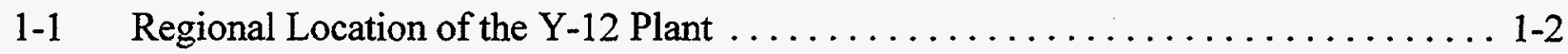

1-2 Locations of Principal Waste Management Sites at the Y-12 Plant $\ldots \ldots \ldots \ldots \ldots$ 1-7

3-1 Geology of the Oak Ridge $Y-12$ Plant $\ldots \ldots \ldots \ldots \ldots \ldots \ldots \ldots \ldots \ldots \ldots \ldots \ldots \ldots \ldots$

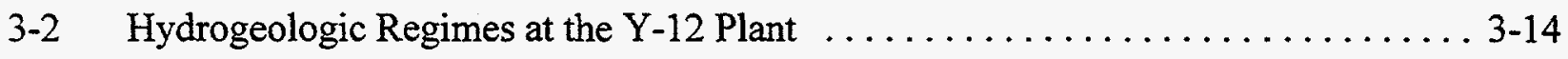

4-1 Line Organization of the Oak Ridge Y-12 Plant GWPP $\ldots \ldots \ldots \ldots \ldots \ldots \ldots .4$

4-2 Matrix Organization of the Oak Ridge Y-12 Plant GWPP $\ldots \ldots \ldots \ldots \ldots \ldots .4$ 


\section{TABLES}

\section{Page}

2-1 Current Regulatory Status of UST Sites at the Y-12 Plant $\ldots \ldots \ldots \ldots \ldots \ldots .2-8$

2-2 Y-12 Plant CERCLA Characterization Areas and Former Operable Units ....... 2-11

3-1 RCRA-Regulated Hazardous-Waste Treatment, Storage,

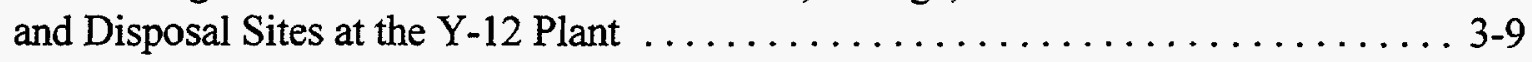




\section{ACRONYMS AND ABBREVIATIONS}

$\begin{array}{ll}\text { APO } & \text { Analytical Project Office } \\ \text { ASO } & \text { K-25 Analytical Services Organization } \\ \text { ARAR } & \text { Applicable or Relevant and Appropriate Requirement } \\ \text { BCV } & \text { Bear Creek Valley } \\ \text { bgs } & \text { below ground surface } \\ \text { BMP } & \text { Best Management Practices } \\ \text { CAP } & \text { Corrective Action Plan } \\ \text { CA } & \text { Characterization Area } \\ \text { CERCLA } & \text { Comprehensive Environmental Response, Compensation, and Liability Act } \\ \text { CM } & \text { Corrective Measures } \\ \text { DOE } & \text { United States Department of Energy } \\ \text { EMD } & \text { Environmental Management Department } \\ \text { EPA } & \text { United States Environmental Protection Agency } \\ \text { ERP } & \text { Environmental Restoration Program } \\ \text { FFA } & \text { Federal Facility Agreement } \\ \text { ft } & \text { feet } \\ \text { GWPO } & \text { Groundwater Program Office } \\ \text { GWPP } & \text { Groundwater Protection Program } \\ \text { GWPS } & \text { Groundwater Protection Standard } \\ \text { GWQAP } & \text { Groundwater Quality Assessment Plan } \\ \text { GWQAR } & \text { Groundwater Quality Assessment Report } \\ \text { GWQR } & \text { Groundwater Quality Report } \\ \text { HSEA } & \text { Health, Safety, Environment, and Accountability (Organization) } \\ \text { HSWA } & \text { Hazardous and Solid Waste Amendments } \\ \text { MOU } & \text { Memorandum of Understanding } \\ \text { ORAU } & \text { Oak Ridge Associated Universities } \\ \text { OREIS } & \text { Oak Ridge Environmental Information System } \\ \text { ORHSP } & \text { Oak Ridge Hydrology Support Program } \\ \text { ORNL } & \text { Oak Ridge National Laboratory } \\ \text { ORR } & \text { Oak Ridge Reservation } \\ \text { ORRHAGS } & \text { ORR Hydrologic and Geologic Studies } \\ \text { OSWER } & \text { Office of Solid Waste and Emergency Response } \\ \text { OU } & \text { Operable Unit } \\ \text { PJ } & \text { Project Engineer } \\ \text { QA QC } & \text { Quality Assurance/Quality Control } \\ \text { QAP } & \text { Quality Assurance Plan } \\ \text { QPP } & \text { Quality Program Plan } \\ \text { RCRA } & \text { Resource Conservation and Recovery Act } \\ \text { RFA } & \text { RCRA Facility Assessment } \\ \text { RFI } & \text { RCRA Facility Investigation } \\ \text { RI/FS } & \text { Remedial Investigation/Feasibility Study } \\ \text { SAS } & \text { Statistical Analysis System } \\ \text { SWDF } & \text { Solid Waste Disposal Facility (nonhazardous waste) } \\ & \end{array}$




\section{ACRONYMS AND ABBREVIATIONS (cont'd)}

SWMU

TDEC

TDHE

TEGD

TPH

TSD

USGS

UST
Solid Waste Management Unit

Tennessee Department of Environment and Conservation

Tennessee Department of Health and Environment

Technical Enforcement Guidance Document

Total Petroleum Hydrocarbons

Treatment, Storage, and Disposal (Unit)

United States Geological Survey

Underground Storage Tank 


\subsection{INTRODUCTION}

The Oak Ridge Y-12 Plant (Y-12 Plant) is owned by the United States Department of Energy (DOE) and managed by Lockheed Martin Energy Systems, Inc. (Energy Systems) under contract No. DEAC05-84OR21400. The Y-12 Plant Groundwater Protection Program (GWPP), which was initiated in 1975, provides for the protection of groundwater resources consistent with Federal, State, and local regulations, and in accordance with DOE orders and Energy Systems policies and procedures.

The Y-12 Plant is located in Anderson County, Tennessee, and is within the corporate limits of the City of Oak Ridge (Figure 1-1). The Y-12 Plant is one of three major DOE complexes that comprise the 37,000-acre Oak Ridge Reservation (ORR) located in Anderson and Roane counties. The Y-12 Plant is located in Bear Creek Valley at an elevation of about 950 feet (ft) above sea level. Bear Creek Valley is bounded on the northwest and southeast, and is isolated from populated areas of Oak Ridge, by parallel ridges that rise about $300 \mathrm{ft}$ above the valley floor. The Y-12 Plant and its fenced buffer area are about 0.6 mile wide by 3.2 miles long and cover approximately 4,900 acres. The main industrialized section encompasses approximately 800 acres.

The Y-12 Plant was built by the U.S. Army Corps of Engineers in 1943 as part of the Manhattan Project. Until 1992, the primary mission of the Y-12 Plant was the production and fabrication of nuclear weapon components. Activities associated with these functions included production of lithium compounds, recovery of enriched uranium from scrap material, and fabrication of uranium and other materials into finished parts for assemblies. Fabrication operations included vacuum casting, arc melting, powder compaction, rolling, forming, heat treating, machining, inspection, and testing.

Currently, the Y-12 Plant is refocusing its technical capabilities and expertise to serve DOE and other DOE-approved customers. The Y-12 Plant continues to serve as a key manufacturing technology center for the development and demonstration of unique materials, components, and 


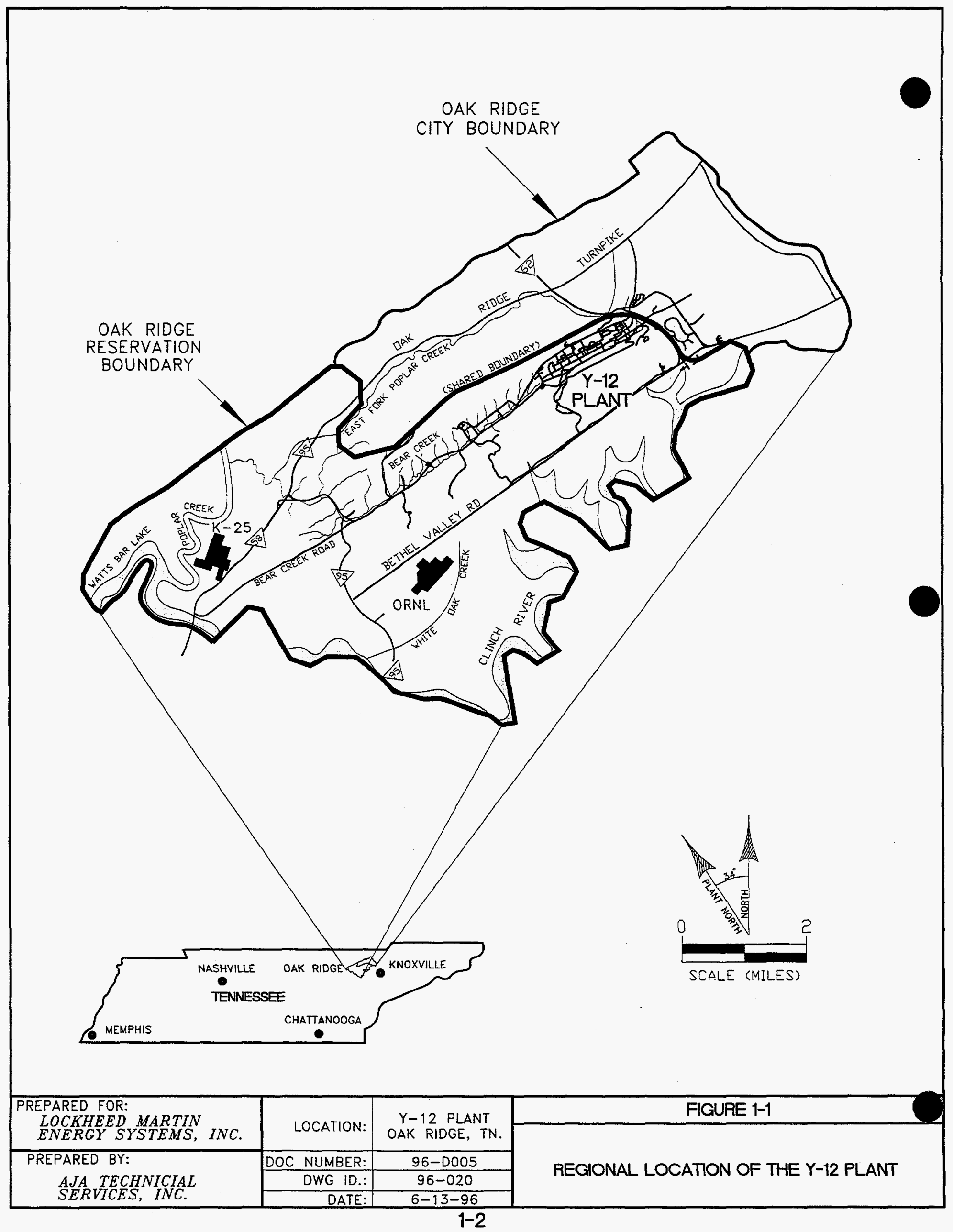


services of importance to the DOE and the nation. Specific focus areas for the Y-12 Plant in coming years include: (1) weapons dismantlement and storage; (2) enriched uranium material warehousing and management; (3) nuclear weapons process technology and development support; (4) Y-12 Plant management/landlord activities including taking standby or shutdown facilities into a safe, legally compliant condition; (5) identifying and managing the decontamination and decommissioning of facilities; (6) providing unique capabilities and technologies not found in the private sector on DOEapproved tasks; (7) transferring technology developed at DOE facilities to enhance our industrial competitive edge in worldwide markets; and (8) maintain and support the National Security Program Office for DOE.

\subsection{PURPOSE AND SCOPE OF THE Y-12 PLANT GWPP MANAGEMENT PLAN}

The Y-12 Plant GWPP Management Plan provides formal structure for the GWPP to ensure internal consistency and ease of external review. This plan meets the requirements for a Groundwater Protection Management Program and a Groundwater Monitoring Plan as described in DOE Order 5400.1 ; and provides the principal tool for effective overall management of the GWPP. The contents of the plan have been assembled to reflect the following scope:

- To define the purpose, policies, and objectives of the Y-12 Plant GWPP.

- To define the regulations, requirements, and guidance applicable to groundwater monitoring at the Y-12 Plant.

- $\quad$ To describe the groundwater monitoring strategies used at the Y-12 Plant to meet the applicable regulations and requirements.

- To provide a brief description of the hydrogeologic conditions present at the Y-12 Plant.

- To define the organizational roles and responsibilities of the Y-12 Plant GWPP personnel.

- To define the interfaces between the Y-12 Plant GWPP and other programs.

- To define the methods, procedures, and schedules to be utilized in meeting the Y-12 Plant GWPP objectives. 
The Y-12 Plant GWPP Management Plan is intended to serve as a "living" document that is routinely updated and reissued. The format is designed to provide for updating of individual sections independent of the rest of the document. The plan as a whole is reviewed annually and revised and reissued every three years. Sections that are revised between reissue dates will be numbered and dated.

Where appropriate, this management plan incorporates material by reference. Materials referenced within this plan are maintained by the Y-12 Plant GWPP as described in Section 4.10, "Recordkeeping and Document Control".

\subsection{PURPOSE, POLICIES, AND OBJECTIVES OF THE Y-12 PLANT GWPP}

The purpose of the Y-12 Plant GWPP is to characterize the hydrogeology, monitor groundwater quality within the area under Y-12 Plant administrative control, and to maintain the monitoring network. These tasks are conducted primarily in support of: (1) groundwater monitoring required under the Resource Conservation and Recovery Act (RCRA) or Tennessee Department of Environment and Conservation (TDEC) solid waste management regulations; (2) the Environmental Restoration Program (ERP), which includes 3004(u) RCRA Facility Investigations (RFIs) and Comprehensive Environmental Response, Compensation, and Liability Act (CERCLA) Remedial Investigations/Feasibility Studies (RI/FS); (3) Underground Storage Tank (UST) corrective actions; (4) compliance with DOE Order requirements for an Environmental Surveillance Program; and (5) best management practice programs. Other programs, which are supported on an as-needed basis include Facilities Decommissioning and Decontamination, UST release investigations, and LowLevel Waste Disposal. Support for the above programs is provided by including technical advice and assistance, sampling and analysis, data management, data interpretation, report preparation, and regulatory negotiation. Subsequent sections of this plan describe the organizational responsibilities, specific methods, and procedures to be utilized in providing the above support.

The policy of the Y-12 Plant GWPP, as dictated by Energy Systems Policy Procedures ESS-EP-101, "Environmental Protection Program" and ESS-EP-134 "Groundwater Protection Program" (Appendix A), is to provide for protection of groundwater resources at the $\mathrm{Y}-12$ Plant consistent with 
federal, state, and local requirements and in accordance with DOE orders and corporate policy. Section 2.0 of this management plan describes applicable Federal and State regulations and DOE orders pertaining to groundwater programs.

The Y-12 Plant GWPP represents a single organizational entity that (1) is the primary point of contact for groundwater monitoring issues and services at the Y-12 Plant; (2) is the primary groundwater information clearinghouse and repository, and (3) provides technical support, maintenance, tracking and broad oversight of all groundwater-related actions at the plant. These functions provide consistency for groundwater monitoring actions, eliminate redundant activities, allow a single, long-term accumulation point for data/information resources, and allow maximization of resources and funding.

\subsection{HISTORY OF THE Y-12 PLANT GWPP}

The Y-12 Plant GWPP evolved from early monitoring efforts that began in 1975 and expanded through the early 1980s. Groundwater monitoring during this period was generally directed towards site-specific characterization objectives, and monitoring activities at each site were loosely coordinated by the Y-12 Plant Health, Safety, Environment, and Accountability (HSEA) Organization without a formal programmatic plan. To more effectively manage the rapid expansion of the monitoring programs after 1984 and in response to the issuance of DOE Order 5400.1, the GWPP was formally established in November 1988. The formal Y-12 Plant GWPP integrated the site-specific monitoring programs, defined standardized programmatic elements (e.g., monitoring well designs), and coordinated data reporting. The following discussion provides details regarding the history of groundwater monitoring at the Y-12 Plant, and the formal establishment of the GWPP.

1975 - 1982

An informal Y-12 Plant GWPP began in 1975 when periodic sampling of groundwater in 17 preexisting wells was initiated to monitor groundwater quality in and around waste disposal sites at the Bear Creek Burial Grounds (Pritz 1983). Beginning in 1981 and continuing through 1982, the Y-12 Plant GWPP was expanded to include annual, biannual, or quarterly sampling of monitoring 
wells at the Chestnut Ridge Sediment Disposal Basin, the S-3 Ponds, and the Bear Creek Burial Grounds (Figure 1-2; Law Engineering 1983).

Also during this period, several groundwater investigations were conducted at the Oak Ridge Y-12 Plant by organizations not directly affiliated with the Y-12 Plant GWPP. Although many of these investigations were completed for engineering and construction site investigations, several were directly related to, or were performed in support of, the Y-12 Plant GWPP. These included an investigation initiated before 1975 by the United States Geological Survey (USGS) that involved the installation of groundwater wells at several locations throughout Bear Creek Valley. Also, the Office of Waste Isolation installed approximately 15 wells in Bear Creek Valley during the period 1976 to 1977 (King et al. 1989). The purpose of these wells was to investigate hydrogeologic conditions related to waste disposal within the valley.

\section{3}

As a result of information obtained by officials of the TDEC, formerly the Tennessee Department of Health and Environment (TDHE), during a Compliance Evaluation Inspection of the past and present waste disposal practices at the Y-12 Plant, representatives of DOE, the United States Environmental Protection Agency (EPA), and the TDEC signed a Memorandum of Understanding (MOU) on May 26, 1983. Item X of the MOU required an investigation of hydrogeologic conditions in Bear Creek Valley west of the Y-12 Plant, and specifically at the S-3 Ponds and at the Chestnut Ridge Sediment Disposal Basin (Figure 1-2). Item XI of the MOU required preparation of a comprehensive monitoring plan for groundwater and surface water at the Y-12 Plant, including sampling locations and monitored parameters. In December 1983, the TDEC issued a Complaint and Order requiring DOE to immediately cease further groundwater contamination by disposal of solid wastes in the Bear Creek Burial Grounds, and to submit a written proposal and schedule (with supporting data and rationale) for remedial action in the Bear Creek watershed area.

In response to Item $\mathrm{X}$ of the MOU, hydrogeologic investigations at the Chestnut Ridge Sediment Disposal Basin, the S-3 Ponds, the Oil Landfarm, and the Bear Creek Burial Grounds (Figure 1-2) 


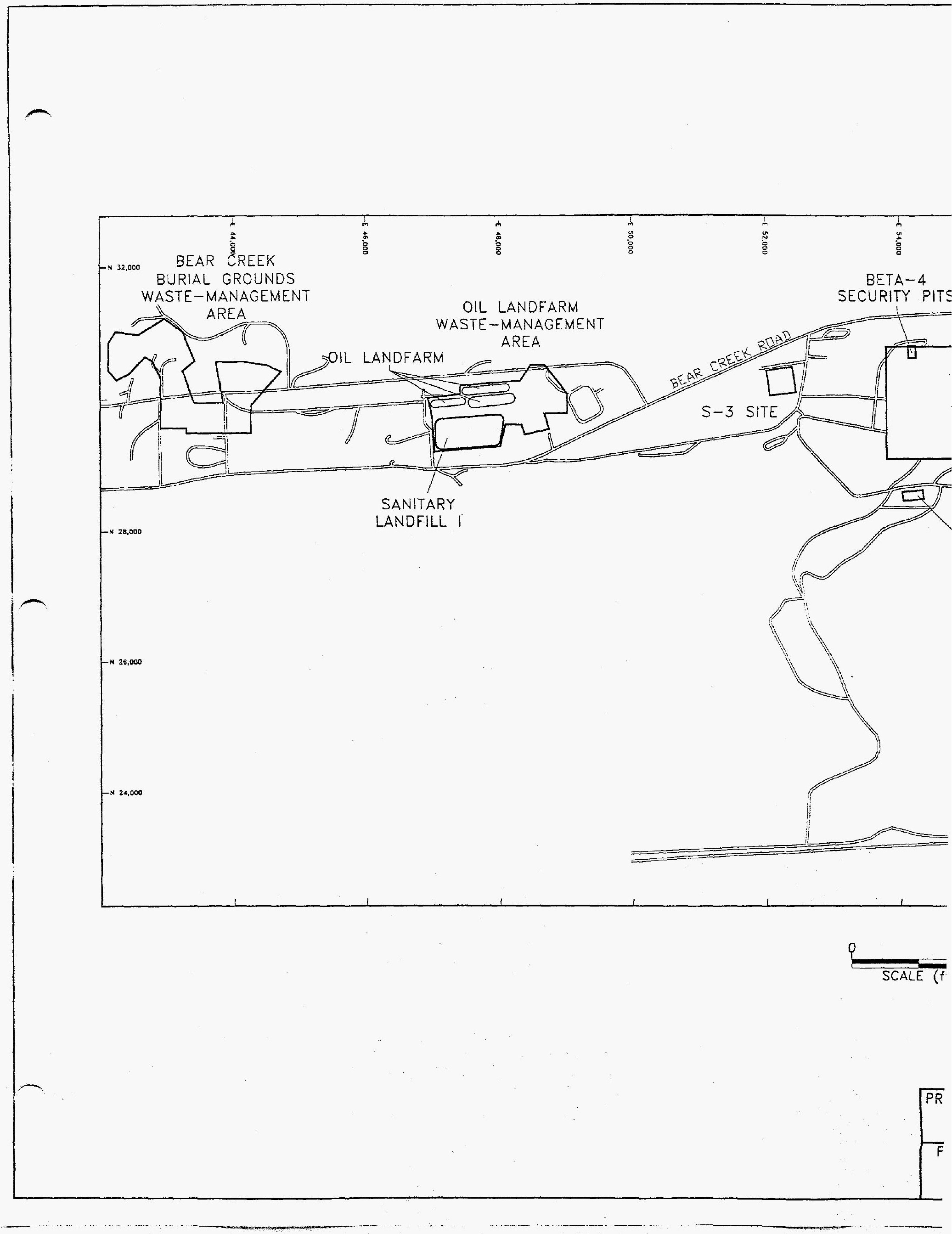


were performed in 1983. A report containing results of groundwater sampling, pumping tests, geological investigations, and recommendations for future studies and groundwater monitoring activities was issued later that year (Law Engineering 1983).

In response to Item XI of the MOU, a master plan for groundwater and surface-water monitoring at the Y-12 Plant was developed and implemented (Pritz 1983). Monitoring under this plan included a network of wells located at the Central Sanitary Landfill II, the S-3 Ponds, the Bear Creek Burial Grounds, the Central Sanitary Landfill I, the Oil Landfarm, the Chestnut Ridge Sediment Disposal Basin, the Chestnut Ridge Security Pits, and the United Nuclear Corporation Disposal Site (Figure 1-2). Analytical parameters and sampling frequencies varied from site to site, depending in part on the quantities and types of wastes disposed of at the various sites. Details of these parameters and sampling procedures are summarized in Pritz (1983).

Also in 1983, an investigation to determine the extent of mercury contamination in soils and groundwater within the $\mathrm{Y}-12$ Plant was initiated after DOE released a report containing preliminary information on mercury losses and unaccounted mercury inventories. This investigation involved the installation of 43 monitoring wells at 24 locations within a 6,000 by $2,000 \mathrm{ft}$ area located in the main industrialized portion of the Y-12 Plant (Figure 1-2), aquifer testing in selected wells, collection of soil and groundwater samples, and laboratory analyses of the samples. Results of the investigation were presented in a report issued in 1984 (Rothschild et al. 1984).

\section{3 - 1985}

Between 1983 and 1984, intensive investigations of hydrogeological conditions at the Bear Creek Burial Grounds, the Oil Landfarm, and the S-3 Ponds were initiated in response to the condition of the Complaint and Order issued by the TDEC requiring DOE to obtain data needed to support an evaluation of remedial alternatives for the Bear Creek watershed area. The investigations involved three phases of well installation and subsequent groundwater sampling and analysis. The first two well installation phases were completed in late 1983 and early 1984 (Bechtel 1984a, 1984b, 1984c, 1984d), and the third phase was completed in late 1984 (Bechtel 1985; Geraghty \& Miller, Inc. 1985a, 1985b). A total of 99 wells were installed: 59 wells at the Bear Creek Burial Grounds, 29 at the Oil Landfarm, and 11 wells at the S-3 Ponds. Analysis and evaluation of the hydrologic and 
water-quality data obtained from the wells was submitted to the TDEC in 1985 (Geraghty \& Miller, Inc. 1985c)

Further investigation was warranted by the results of the hydrogeologic investigations performed in 1983 and 1984; thus, in 198516 additional monitoring wells were installed at the Bear Creek Burial Grounds, the Oil Landfarm, the Central Sanitary Landfill I, and the S-3 Ponds (Geraghty \& Miller, Inc. 1986). These wells were designed primarily to investigate the deeper portions of the groundwater flow system at these waste disposal sites. Typically, the wells were installed adjacent to other wells to form clusters. Construction data and hydrogeological information for the wells were summarized in a report issued in 1986 (Geraghty \& Miller, Inc. 1986). An evaluation of the groundwater quality data and an analysis of deep-well recovery behavior were presented in a report issued in 1987 (Geraghty \& Miller, Inc. 1987a).

Also in 1985, 55 monitoring wells were installed in compliance with requirements of RCRA regulations and for initial hydrogeological characterization purposes at several non-RCRA waste-management sites. For RCRA compliance purposes, 5 monitoring wells were installed at the Chestnut Ridge Security Pits, 11 wells at New Hope Pond, 6 wells at the Chestnut Ridge Sediment Disposal Basin, and 7 wells at Kerr Hollow Quarry. For hydrogeologic characterization purposes, 6 monitoring wells were installed at the Beta-4 Security Pits, 5 wells at the Ravine Disposal Site, 7 wells at Rogers Quarry, and 3 wells at the United Nuclear Corporation Disposal Site (Figure 1-2). Groundwater samples were collected from each well and water-levels in the wells were regularly measured. Information on site investigation planning, well placement and construction, site hydrogeology, a preliminary evaluation of the hydrogeologic information, and groundwater-quality data obtained from the wells is provided in three separate reports (Haase et al. 1987a, 1987b, and 1987c).

Five monitoring wells also were installed in 1985 at several locations in cooperation with a continuing hydrogeologic investigation initiated by the USGS before 1975. Additionally, deep core holes were drilled for hydrogeologic characterization purposes at Kerr Hollow Quarry and the Chestnut Ridge Sediment Disposal Basin (Figure 1-2). 
A hydrogeologic investigation in support of the Y-12 Plant GWPP also was performed during 1985 by researchers with the Oak Ridge National Laboratory (ORNL). During this investigation, 10 core holes were installed at 4 locations in the vicinity of the Oak Ridge Y-12 Plant to characterize subsurface geological and hydrological conditions to depths of $1200 \mathrm{ft}$ below ground surface (King and Haase 1987 and 1989).

\section{6 - 1989}

Continued investigations were performed between 1986 and 1989 in support of RCRA groundwater monitoring requirements and primarily involved the installation and sampling of additional monitoring wells. During this period, 160 monitoring wells were added to the well network at the Y-12 Plant. These included 6 wells at New Hope Pond, 6 wells (and 1 exploratory core hole) at the Chestnut Ridge Security Pits, 2 wells at the Chestnut Ridge Sediment Disposal Basin, 14 wells at the S-3 Ponds, 31 wells at the Bear Creek Burial Grounds, and 101 wells installed at 13 other waste management sites associated with the Y-12 Plant. Groundwater samples were collected from all of the wells installed during this period, with most of the wells sampled on a quarterly frequency. The analytical data obtained from these wells and an interpretation of the data were presented in a series of site-specific reports submitted to the TDEC and the EPA.

Between 1987 and 1989, an intensive hydrogeological characterization was performed by ORNL researchers in support of the Y-12 Plant GWPP. This investigation included installation of groundwater investigation wells at a site in Bear Creek Valley approximately 5 miles west of the Y-12 Plant (Lee and Ketelle 1989).

By 1989 , the original comprehensive surface water and groundwater monitoring plan for the Y-12 Plant (Pritz 1983) had been rendered obsolete by the expansion of regulatory requirements and groundwater monitoring activities performed under the Y-12 Plant GWPP. In addition, DOE Order 5400.1 was issued in November 1988, which specified the establishment of a formal groundwater protection management program at each DOE site. The order identified multiple objectives for groundwater resource monitoring and directed that the program meet high standards of quality. A formal Y-12 Plant GWPP was created (King and Hease 1990) and technical objectives of the 
program were reviewed. Based on the information obtained since 1983, a completely revised comprehensive groundwater monitoring plan (Comprehensive Monitoring Plan) for the Y-12 Plant was prepared (Geraghty \& Miller, Inc. 1990). The revised Comprehensive Monitoring Plan contained a groundwater and surface-water quality monitoring strategy for the Y-12 Plant GWPP based on a technical approach incorporating the characteristics of the hydrogeologic system at the Y-12 Plant and compliance with all applicable State and Federal Regulations, DOE Orders, and EPA technical guidance.

\section{0 - Present}

Beginning in September 1990 and continuing until September 1992, the installation and sampling of 68 monitoring wells were performed under two components of the technical framework presented in the Comprehensive Monitoring Plan: the Maynardville Exit Pathway Program and the Upper East Fork Poplar Creek Phase I Monitoring Network (Grid Program). The Maynardville Exit Pathway Program was initiated in response to DOE Order 5400.1 to investigate contaminant transport within the Maynardville Limestone, the principal groundwater flow path in the Bear Creek Valley. The Grid Program was also initiated in response to DOE Order 5400.1 to provide effluent and surveillance data on extent of contamination in shallow groundwater within the industrialized portions of the Y-12 Plant complex.

Also in 1990, a separate program (Westbay Program) was initiated in conjunction with the Maynardville Exit Pathway Program. This program involved the installation of multiport monitoring systems in 6 deep (approximately 600 to 1,400 ft) core holes (Dreier et al. 1993).

Effective in January 1992, the DOE, the EPA, and the TDEC negotiated a Federal Facility Agreement (FFA) regarding environmental restoration under CERCLA on the ORR (DOE 1991), which was added to the National Priority List in November 1989. This agreement superseded the HSWA permit and CERCLA became the primary regulatory driver for several RCRA TSD units and SWMUs at the Y-12 Plant. As such, the DOE appealed the applicability of RCRA post-closure care, corrective action, and groundwater monitoring requirements to CERCLA Operable Units (OUs).

In April 1993, the DOE, TDEC, and Energy Systems signed an Agreed Order for the RCRA post-closure permit for the S-3 Site, thereby resolving the appeal and formally agreeing to proceed 
with CERCLA as a lead regulatory program with RCRA as an applicable, or relevant and appropriate requirement (ARAR). Under this agreement, RCRA will be applied as an ARAR to the extent that post-closure maintenance and care of former TSD facilities will be conducted in compliance with the terms of RCRA post-closure permits. Groundwater monitoring is to be integrated with the CERCLA RI/FS programs, with RCRA corrective action deferred to CERCLA. Accordingly, groundwater monitoring data reporting will comply with RCRA post-closure permit conditions as well as RI/FS requirements. Per agreement with TDEC, three RCRA post-closure permits will be issued for the Y-12 Plant encompassing each of the three hydrogeologic regimes. Specific requirements for interim status sites within each regime will be incorporated into the permits as separate modifications.

Efforts were initiated early in 1994 by DOE and Energy Systems to modify the FFA strategy for RI/FS implementation. The FFA originally defined two types of CERCLA OUs for which an RU/FS would be performed: (1) source control OUs comprised of individual or groups of waste management sites, and (2) integrator OUs that encompass groundwater and surface water, independent of the source control OUs that may contribute to the contamination of these media (DOE 1994a). However, as the RIs for OUs within Bear Creek Valley (BCV) progressed, it became increasingly evident that separation of source control and integrator OUs was not the most technically feasible approach to implementation of the RI/FS process. An agreement was reached among regulatory agencies and the DOE to proceed, where feasible, with an integrated RI/FS approach. In the integrated approach, source and integrator OUs are addressed concurrently in a Characterization Area (CA) defined by watershed boundaries, and specific sites or locations of highest risk or concern are targeted for focused studies. Additionally, efforts were initiated to develop a conceptual model of groundwater flow and contaminant migration that is tailored to the specific characteristics of the groundwater flow system in BCV. 


\subsection{APPLICABLE REGULATIONS, REQUIREMENTS, AND GUIDANCE FOR GROUNDWATER MONITORING}

The following sections provide an overview of the applicable requirements for groundwater monitoring at the Y-12 Plant. There are over 200 sites at the Y-12 Plant at which hazardous or nonhazardous wastes are currently or have previously been managed, including above and below-ground storage tanks, landfills, surface impoundments, waste piles, land treatment areas, and scrap and storage yards. The primary sites at which groundwater monitoring has been or currently is being performed are shown on Figure 1-2. Performance standards for groundwater monitoring at these sites are specified in EPA and TDEC regulations promulgated under RCRA and CERCLA, DOE Orders, and TDEC non-hazardous solid waste management regulations. Recommended groundwater monitoring protocols, procedures, and methods implemented to achieve these performance standards are presented in technical guidance documents issued by the EPA, TDEC, DOE, and Energy Systems. A general overview of these groundwater monitoring requirements is provided in the following sections.

\subsection{RCRA REQUIREMENTS}

Several waste management sites associated with the Y-12 Plant have been or are currently subject to State and Federal regulations promulgated under RCRA. Federal RCRA regulations are contained in 40 CFR Parts 260 - 281, and are administered at the Y-12 Plant by EPA Region IV headquarters personnel in Atlanta, Georgia. State of Tennessee RCRA regulations are contained in TDEC Rule 1200-1-11, and are administered by the TDEC Division of Solid Waste Management office located in Nashville. Additionally, technical issues and general regulatory oversight also involve the TDECDOE Oversight office located in Oak Ridge.

The RCRA regulations governing groundwater monitoring are specified for: (1) hazardous waste treatment, storage, and disposal (TSD) facilities; and (2) USTs. Regulated TSD facilities include tanks, surface impoundments, waste piles, land treatment areas, and landfills used for hazardous waste management. Regulated USTs are those used to store hazardous substances regulated under 
CERCLA (40 CFR Part 302) and liquid petroleum products. Those USTs containing RCRA hazardous wastes are addressed in the regulations for TSD facilities.

\subsubsection{RCRA TSD Facilities}

The requirements of the Federal RCRA regulations for groundwater monitoring at TSD facilities are contained in 40 CFR Parts 264 and 265; corresponding TDEC regulations are specified in Rule 1200-1-11-.07. The State and Federal RCRA regulations are functionally equivalent. Both establish similar groundwater monitoring requirements for both non-permitted (interim status) TSD facilities and permitted TSD facilities. The basic monitoring requirements for each category are discussed in the following sections.

\subsubsection{Interim Status TSD Facilities}

Groundwater monitoring at TSD facilities granted RCRA interim status is performed to ensure that groundwater quality is monitored and evaluated until a RCRA operating or post-closure permit for the site is issued, whereupon the monitoring programs outlined in the permit are implemented. To achieve this goal, the RCRA interim status regulations establish a two-stage monitoring program designed to detect a contaminant release (detection monitoring), and characterize the extent, rate of migration, and concentration distribution of hazardous waste and hazardous waste constituents released from the site (assessment monitoring).

\section{Detection Monitoring}

Performance requirements for interim status detection monitoring are contained in 40 CFR Part 265 and TDEC Rule 1200-1-11-.07. Provided no contaminant release is detected, this monitoring program is performed until a permit for the site is issued, and is subsequently continued in accordance with the requirements for permitted TSD facilities.

Detection monitoring involves semiannual sampling from a minimum of one upgradient well and three downgradient wells, analysis of the samples for a spected suite of indicator and water quality parameters, and statistical comparison to baseline values determined from one year of quarterly monitoring. Cochran's Approximation of the Behrens-Fisher Student t-test, or TDEC-approved 
alternative method, must be used in the statistical comparisons. If a statistically significant increase is determined for any of the indicator parameter concentrations in samples from the downgradient wells, then additional confirmation sampling or a false-positive demonstration may be conducted. If a statistical increase of contaminant concentrations is confirmed, then assessment monitoring is initiated.

\section{Assessment Monitoring}

Assessment monitoring may be triggered from detection monitoring as discussed in the preceding section, or may be initiated from the outset at sites where groundwater contamination is suspected or known to be present. The goal of assessment monitoring is to determine the rate and extent of contaminant migration, and to provide information needed to support future decisions regarding the need for and extent of corrective action. Groundwater sampling during assessment monitoring must be performed quarterly in accordance with a Groundwater Quality Assessment Plan (GWQAP). The GWQAP must specify the monitoring-well network, sampling and analysis procedures, procedures for data evaluation, and a schedule of implementation. Monitoring results must be submitted annually to the TDEC in a Groundwater Quality Assessment Report (GWQAR).

\subsubsection{Permitted TSD Facilities}

The RCRA regulations for permitted TSD facilities that have been closed establish a three-stage program consisting of detection monitoring, compliance monitoring, and corrective-action monitoring. Detection monitoring is initially implemented, and if a contaminant release is detected and subsequently confirmed, compliance monitoring is initiated to monitor the severity of the release. If the compliance monitoring results indicate that concentration limits specified in the facility permit have been exceeded, corrective-action monitoring is initiated to determine both the extent of the release and the effectiveness of the corrective actions implemented to mitigate the release. Statistical analysis procedures are the mechanisms which "trigger" the progression from one program to the next. 


\section{Detection Monitoring}

For new hazardous waste TSD units or closed interim status units where no groundwater contamination has occurred, detection monitoring is performed to determine if the site ever releases contaminants into the uppermost aquifer in quantities sufficient to cause a significant change in groundwater quality (EPA 1985).

In general, detection monitoring for a permitted TSD facility requires monitoring downgradient of the site for a select set of indicator parameters specified in the facility permit. The data are statistically compared to their respective baseline values established from quarterly sampling of background wells over a period of at least one year. If a statistically significant change in the level of any monitored parameter is detected and confirmed, then sampling for RCRA Part 264 Appendix IX constituents must be immediately performed to enable a complete chemical characterization of the contaminant release. Upon completion of this characterization, compliance monitoring is initiated at the site (EPA 1985).

\section{Compliance Monitoring}

The goal of compliance monitoring is to determine whether the concentrations of Appendix IX constituents have exceeded the limits specified in the facility permit as part of the Groundwater Protection Standard (GWPS). The GWPS consists of: (1) a list of all the Appendix IX constituents present in groundwater at the site; (2) the maximum allowable concentration of each constituent; (3) the location where the GWPS is applied (the point of compliance); and (4) the period during which the GWPS applies (the compliance period). For permitted TSD units, the GWPS is established through a permit modification after a contaminant release has been detected and confirmed, and Appendix IX sampling to initially characterize the release has been completed. For interim status TSD units, the GWPS is established in the initial permit application.

During compliance monitoring, groundwater samples from all wells at the point of compliance must be analyzed quarterly for all of the constituents listed in the GWPS, and annually for all Appendix IX constituents. Results of the quarterly analyses are statistically evaluated in accordance with a procedure specified in the facility permit. If the statistical evaluation suggests that the concentration 
limits specified in the GWPS have been exceeded in any well at the point of compliance, a corrective-action program must be initiated to bring the facility back into compliance with its GWPS (EPA 1985).

\section{Corrective-Action Monitoring}

Detailed performance requirements for corrective-action monitoring are not specified in the RCRA regulations; the regulations require only that the monitoring program be sufficient to demonstrate the effectiveness of the corrective-action program. Sampling frequencies, analytical parameters, and monitoring-well networks are established on a case-by-case basis, but monitoring results must be reported to the TDEC semiannually. Corrective-action monitoring may be discontinued (and compliance monitoring reinstated) if results show that contaminant concentrations have remained below the GWPS-specified concentration limits for three consecutive years.

\subsubsection{Underground Storage Tanks}

Federal performance standards for USTs are defined in 40 CFR Part 280 and the corresponding State of Tennessee UST regulations are contained in TDEC Rule 1200-1-15. In general, the TDEC regulations for USTs require groundwater monitoring as one of several acceptable release detection alternatives, during site characterization to determine the extent of a release from the UST, and during corrective action.

\section{Release Detection Monitoring}

If groundwater monitoring is selected as the method of release detection, the TDEC regulations specify minimum requirements for the location and depth of the monitoring wells, construction materials and well installation methods, well security, and well-design standards that enable detection of at least one-eighth of an inch of free product. To ensure compliance with these performance standards and to establish the number and positioning of wells, the UST regulations require a preliminary site assessment of the area within and immediately below the UST system. 


\section{Environmental Assessment Monitoring}

Upon confirmation of a release at an UST, an initial site characterization is required to obtain information regarding the nature of the release. A complete environmental assessment of the release is required if: (1) there is evidence that groundwater (supply) wells have been affected by the release; (2) recoverable free product is present; (3) there is evidence that contaminated soils may be in contact with groundwater; or (4) the TDEC requests a full characterization of the release.

Groundwater monitoring to characterize the extent of a release from a petroleum UST is performed as part of corrective action required under TDEC Rule 1200-1-15-.06(7). No performance standards are specified in these regulations but the monitoring program must conform to the standards contained in "Environmental Assessment Guidelines" (TDEC 1992a). Technical issues addressed in this guidance document include soil boring and well-installation methods and procedures, well development, water-level measurements, groundwater sampling, disposal of purge and development water, analytical methods, equipment decontamination, monitoring-well abandonment, quality assurance/quality control, and data collection. Results of the assessment must be submitted to the TDEC in an Environmental Assessment Report prepared in accordance with "Environmental Assessment Report Guidelines" (TDEC 1992b).

\section{Corrective-Action Monitoring}

Preparation of a corrective-action plan (CAP) is required by the TDEC regulations if contaminant concentrations determined during the environmental assessment exceed action levels for soil and groundwater specified in Appendix 3 of TDEC Rule 1200-1-15-.06. Groundwater action levels are defined only for benzene and Total Petroleum Hydrocarbons (TPH). If upgradient benzene and TPH concentrations (reference concentrations) are greater than the TDEC action levels due to influences other than a subject UST, then the reference concentrations are used as the action levels.

Different groundwater action levels for benzene and TPH are defined by the TDEC for drinking-water and non-drinking water supplies. The procedure that must be used to differentiate drinking-water and non-drinking water supplies is outlined in "Environmental Assessment 
Guidelines" (TDEC 1992a). This procedure involves a water-use survey, groundwater sampling and laboratory analysis, and aquifer testing (pump tests).

A CAP must be submitted to the TDEC within 150 days after initiation of the contamination assessment at the UST, and must follow the format specified in "Corrective Action Plan Guidelines" (TDEC 1992c). The CAP must describe the technical approach that will be implemented to actively remediate, entirely encompass, and prevent further migration of the contaminant plume, and include technical details for groundwater monitoring to determine the effectiveness of the corrective-action. Results of corrective action and corrective-action monitoring must be submitted to the TDEC monthly for the first three months of remedial activities, and quarterly thereafter throughout the duration of the corrective-action program.

Corrective action may be discontinued when benzene and TPH concentrations no longer exceed the Appendix 3 action levels or the reference concentrations (if higher than the Appendix 3 action levels). Typically, corrective-action monitoring is continued quarterly for at least one year after corrective-action is discontinued to ensure that remedial efforts have achieved protection of human health and the environment.

In January 1994, the TDEC Division of USTs issued new guidance allowing owner/operators of USTs to evaluate or "rank" individual USTs for potential long-term, semiannual monitoring in lieu of proposed corrective action; TDEC approval of the UST ranking supersedes a remediation scenario with a "monitoring-only" approach. This ranking must be conducted annually based on current monitoring results. A comparative result can be achieved through the pursuit of a site-specific standard for an individual UST site. TDEC approval of a site-specific standard request also supersedes a remediation scenario with "monitoring-only".

The progressive, regulatory status of UST sites for which activities are currently being conducted is outlined in Table 2-1. Semiannual monitoring currently conducted at Building 9201-1 and the Rust Garage Facility is limited in scope (total petroleum hydrocarbons and benzene, toluene, 
Table 2-1. Current Regulatory Status of UST Sites at the Y-12 Plant

\begin{tabular}{|c|c|c|c|c|c|c|}
\hline \multirow{3}{*}{$\begin{array}{c}\begin{array}{c}\text { Groundwater } \\
\text { Monitoring }\end{array} \\
\begin{array}{c}\text { UST } \\
\text { Locations }\end{array}\end{array}$} & \multicolumn{6}{|c|}{ REGULATORY STATUS } \\
\hline & \multicolumn{2}{|c|}{$\begin{array}{c}\text { Corrective Action } \\
\text { Plan }\end{array}$} & \multicolumn{2}{|c|}{ Site Ranking Form } & \multicolumn{2}{|c|}{$\begin{array}{c}\text { Site-Specific Standard } \\
\text { Request }\end{array}$} \\
\hline & Submitted* & Approved & Submitted* & Approved & Submitted* & Approved \\
\hline $\begin{array}{l}\text { Building } \\
\text { 9754/9754-2 East } \\
\text { End Fuel Facility }\end{array}$ & $7 / 6 / 92$ & $5 / 11 / 93$ & NA & NA & $4 / 21 / 94$ & Pending \\
\hline $\begin{array}{l}\text { Building 9201-1 } \\
\text { (Tank 2331-U) }\end{array}$ & $7 / 21 / 92$ & $12 / 7 / 93$ & $4 / 20 / 94$ & $5 / 23 / 94$ & NA & NA \\
\hline $\begin{array}{l}\text { Building 9204-2 } \\
\text { (Tanks 0134-U) }\end{array}$ & $8 / 21 / 92$ & $5 / 7 / 93$ & $2 / 1 / 95$ & $3 / 9 / 95$ & NA & NA \\
\hline $\begin{array}{c}\text { Buildings } \\
\text { 9754-1/9720-15 } \\
\text { Rust Garage Area }\end{array}$ & $5 / 11 / 92$ & NA & $2 / 28 / 94^{* *}$ & $3 / 7 / 94 * *$ & 9/23/94 & Pending \\
\hline
\end{tabular}

Notes:

* DOE to TDEC

** Site ranking exceeded TDEC criteria; thus, site-specific standard request submitted to TDEC

NA Not Applicable 
and xylenes) and is performed by the Compliance Monitoring Services staff at the Y-12 Plant Environmental Management Department.

\subsubsection{RCRA Solid Waste Management Units}

Section 3004(u) of the 1984 the Hazardous and Solid Waste Amendments (HSWA) set forth additional corrective-action requirements for facilities seeking RCRA permits. These requirements addressed TSD units and SWMUs, which were defined as any discernable waste management unit from which hazardous constituents might migrate, irrespective of whether the unit was intended for management of solid and/or hazardous waste. In response to the HSWA, the EPA developed technical guidance regarding contamination investigation/corrective action at SWMUs. The TDEC has not yet received primacy for enforcement of the HSWA at RCRA facilities; EPA Region IV is responsible for HSWA enforcement at the Y-12 Plant.

The EPA technical guidance documents outline a three-phase program consisting of a RCRA Facility Assessment (RFA), a RCRA Facility Investigation (RFI), and the selection and implementation of Corrective Measures (CM) (EPA 1986a). Although groundwater monitoring may be required in some instances, a RFA usually involves a "desk top" review of existing information to identify all SWMUs at the facility and those SWMUs needing further investigation under an RFI.

If it is determined during the RFA that contaminants have been, or are suspected to have been released to the groundwater system, the RFI must include monitoring to determine the extent of contamination. The RFI guidance documents outline a technical approach consisting of an initial monitoring phase to determine if a contaminant release has occurred, and subsequent monitoring phases (if needed) to determine the chemical composition of the contaminant plume, horizontal and vertical plume boundaries, and the rate of contaminant migration (EPA 1986a). Specific details regarding the monitoring program, including analytical parameters, sampling frequency and duration, and the monitoring-well network are specified in an RFI Work Plan approved by the EPA. 


\subsection{CERCLA REQUIREMENTS}

Federal CERCLA regulations are contained in 40 CFR Part 300; draft State of Tennessee CERCLA regulations were proposed in October 1992 by the TDEC Division of Superfund and are contained in TDEC Rule 1200-1-13. While the RCRA regulations outline in detail the requirements for specific groundwater monitoring programs, CERCLA regulations include groundwater monitoring as one of several aspects of the RI/FS process used to assess the extent of contamination and to screen and select an appropriate remedial alternative. Groundwater monitoring is most commonly performed during the $\mathrm{RI}$, which is the site characterization mechanism used to obtain the data needed for the FS.

Like the RFI process for RCRA-regulated SWMUs, the specific requirements for groundwater monitoring during an RI/FS are recommended in EPA technical guidance documents. These guidance documents outline an investigative approach focused on OUs. Specific details regarding analytical parameters, monitoring frequency and duration, and the monitor-well network are contained in a work plan that must be approved by the EPA before the RI is initiated. When a sufficient amount of data have been generated to support selection of remedial alternatives under the FS, the need for continued monitoring efforts are reevaluated.

As noted in Section 1.3, an agreement was reached in 1994 between the regulatory agencies and the DOE to proceed, where feasible, with an integrated RI/FS approach at the Y-12 Plant. Under this approach, source and integrator OUs are addressed concurrently in CAs defined by watershed boundaries, and specific sites or locations of highest risk or concern are targeted for focused studies. Additionally, efforts are in progress to develop conceptual models for groundwater flow in each CA. The CAs defined for the Y-12 Plant and the sites that comprised the former OUs included in each CA are listed in Table 2-2 and shown on Figure 1-2.

\subsection{NONHAZARDOUS SOLID WASTE DISPOSAL FACILITIES}

As revised in December 1993, the TDEC issued final regulations (TDEC Rule 1200-1-7-.04) which established 6 types of non-hazardous solid waste-processing and disposal facilities: (1) sanitary municipal landfills (Class I facilities); (2) industrial landfills (Class II facilities); (3) landfills for 
Table 2-2. Y-12 Plant CERCLA Characterization Areas and Former Operable Units UPPER EAST FORK POPLAR CREEK CHARACTERIZATION AREA

\begin{tabular}{|c|c|c|}
\hline Former OU Designation/Type & Status & Individual remediation units \\
\hline $\begin{array}{l}\text { UEFPC OU } 01 \\
\text { Groundwater and Surface Water } \\
\text { (Integrator) }\end{array}$ & RI/FS & $\begin{array}{l}\text { East Fork Regime, UEFPC, Union Valley } \\
\text { Mercury Contaminated Areas }\end{array}$ \\
\hline $\begin{array}{l}\text { UEFPC OU } 02 \\
\text { (Source Control) }\end{array}$ & ROD & Nitric Acid Pipeline \\
\hline $\begin{array}{l}\text { UEFPC OU } 03 \\
\text { (Source Control) }\end{array}$ & RIFS & $\begin{array}{l}\text { Salvage Yard Oil Storage } \\
\text { Salvage Yard Oil/Solvent Drum Storage Area } \\
\text { Machine Coolant Storage Tanks } \\
\text { Waste Coolant Processing Facility } \\
\text { S-2 Site } \\
\text { Coal Pile Trench } \\
\text { Salvage Yard Drum Deheader } \\
\text { Salvage Yard Scrap Metal Storage Area } \\
\text { Building } 81-10 \text { Area } \\
\text { Tank 2063-U }\end{array}$ \\
\hline
\end{tabular}

\section{BEAR CREEK VALLEY CHARACTERIZATION AREA}

\begin{tabular}{|c|c|c|}
\hline Former OU Designation (Type) & Status & Individual remediation units \\
\hline $\begin{array}{l}\text { Bear Creek OU } 01 \\
\text { (Source Control) }\end{array}$ & RI/FS & $\begin{array}{l}\text { Hazardous Chemical Disposal Area- } \\
\text { Boneyard/Burnyard } \\
\text { S-3 Ponds } \\
\text { Oil Retention Pond No. } 1 \\
\text { Oil Retention Pond No. } 2 \\
\text { Oil Landfarm } \\
\text { Bear Creek Burial Grounds } \\
\text { Sanitary Landfill I } \\
\text { Rust Spoil Area }\end{array}$ \\
\hline $\begin{array}{l}\text { Bear Creek OU } 02 \\
\text { (Source Control) }\end{array}$ & ROD & $\begin{array}{l}\text { Spoil Area I } \\
\text { SY-200 Yard }\end{array}$ \\
\hline $\begin{array}{l}\text { Bear Creek OU } 03 \\
\text { (Source Control) }\end{array}$ & RU/FS & Bear Creek Flood Plain Soils \\
\hline $\begin{array}{l}\text { Bear Creek OU } 04 \\
\text { Groundwater and Surface Water } \\
\text { (Integrator) }\end{array}$ & RI/FS & $\begin{array}{l}\text { Bear Creek Groundwater, Surface Water, and } \\
\text { Sediment }\end{array}$ \\
\hline
\end{tabular}


Table 2-2. (cont'd)

CHESTNUT RIDGE CHARACTERIZATION AREA

\begin{tabular}{|c|c|c|}
\hline Former OU Designation (Type) & Status & Individual remediation units \\
\hline $\begin{array}{l}\text { Chestnut Ridge OU } 01 \\
\text { (Source Control and Groundwater) }\end{array}$ & $\mathrm{RI} / \mathrm{FS}$ & Chestnut Ridge Security Pits \\
\hline $\begin{array}{l}\text { Chestnut Ridge OU } 02 \\
\text { (Source Control and Groundwater) }\end{array}$ & $\mathrm{RU} / \mathrm{FS}$ & Filled Coal Ash Pond/McCoy Branch \\
\hline $\begin{array}{l}\text { Chestnut Ridge OU } 03 \\
\text { (Source Control and Groundwater) }\end{array}$ & RI/FS & United Nuclear Corporation Site \\
\hline $\begin{array}{l}\text { Chestnut Ridge OU } 04 \\
\text { (Source Control and Groundwater) }\end{array}$ & RU/FS & Rogers Quarry/Lower McCoy Branch \\
\hline \multicolumn{3}{|c|}{ LOWER EAST FORK POPLAR CREEK CHARACTERIZATION AREA } \\
\hline Former OU Designation/Type & Status & Individual remediation units \\
\hline $\begin{array}{l}\text { Lower EFPC OU } \\
\text { (Source Control and Groundwater) }\end{array}$ & RU/FS & Lower East Fork Poplar Creek \\
\hline
\end{tabular}

Source: DOE 1994 
farming wastes or woody refuse (Class III facilities); (4) landfills for construction, demolition, and other inert wastes (Class IV facilities); (5) land farming facilities (Class V facilities); and (6) surface impoundments used for disposal of non-hazardous wastes (Class VI facilities). Groundwater monitoring is required at all new and existing Class I, II, and III facilities. The level of monitoring effort depends on the type of facility; the most stringent monitoring is required at Class I facilities and the least stringent at Class III facilities. Monitoring at Class IV, V, and VI facilities is not required unless specifically requested by the TDEC.

Specific standards for groundwater monitoring at these Solid Waste Disposal Facilities (SWDFs) are contained in TDEC Rule 1200-1-7-.04, which generally requires sampling from a minimum of 3 monitor wells ( 1 upgradient and 2 downgradient) in accordance with an approved groundwater sampling and analysis plan. In addition, the TDEC solid waste regulations share the GWPS and compliance boundary concepts contained in the RCRA regulations. Detection monitoring at the compliance boundary for the SWDF is required to determine compliance with concentration limits specified in the facility permit as part of the GWPS. If the monitoring results indicate that the GWPS has been exceeded at the compliance boundary, assessment monitoring is implemented to characterize the extent of the release.

\subsection{DOE ORDERS}

Several DOE orders prescribing the manner in which DOE operations are to be conducted reference groundwater protection and monitoring requirements. Below is a list of those orders and a summary of the requirements that pertain to the GWPP.

\section{Order 5400.1, "General Environmental Protection Program," 6-29-90:}

States DOE policy to conduct operations "in compliance with the letter and spirit of applicable environmental statutes, regulations, and standards." Establishes requirements and guidance for radiological effluent monitoring and environmental surveillance conducted in support of DOE operations and activities. Directs that environmental surveillance programs be conducted to: (1) determine whether the public and the environment are adequately protected during DOE operations and whether operations are in compliance with DOE and other applicable Federal, State, and local radiation standards and requirements; and (2) be capable of detecting and 
quantifying unplanned releases; and (3) that they meet the high standards of quality and creditability. Requires establishment of a groundwater protection management program at each DOE site. Requires groundwater monitoring to determine and document the effects of DOE operations on groundwater quality and quantity. Requires development of specific groundwater monitoring plans. Requires an annual site environmental monitoring report, which includes a groundwater protection section.

The environmental surveillance program outlined in DOE Order 5400.1 requires monitoring of terrestrial and aquatic foodstuffs, soil and sediment, surface water and groundwater. With respect to groundwater, DOE Order 5400.1 requires that "ground waters that may potentially be affected by DOE operations be monitored to determine and document the effects of such operations on groundwater quality and quantity and to demonstrate compliance with applicable Federal and State laws and regulations".

DOE Order 5400.1 recommends that groundwater monitoring at DOE facilities be conducted on-site and in the vicinity of DOE facilities to:

(1) Obtain data for the purpose of determining baseline conditions of groundwater quality and quantity;

(2) Demonstrate compliance with and implementation of all applicable regulations and DOE orders;

(3) Provide data for early detection of groundwater pollution or contamination;

(4) Identify existing and potential groundwater contamination sources and to maintain surveillance of these sources; and

(5) Provide data upon which decisions can be made concerning land disposal practices and the management of groundwater resources.

In addition to the above listed general requirements, DOE Order 5400.1 also contains recommendations regarding monitoring well construction and location, groundwater sampling frequency, sampling and analytical methods, sample sizes, and methods of sample preservation.

\section{Order 5400.2A, "Environmental Compliance Issue Coordination," 1-31-89:}

Requires coordination of environmental issues that are of significance to DOE, including groundwater protection. 


\section{Order 5400.3, "Hazardous and Radioactive Mixed Waste Management," 2-22-89:}

Requires all DOE hazardous and radioactive mixed wastes be managed according to the requirements of Subtitle C of RCRA and the Atomic Energy Act, respectively. Also requires that groundwater monitoring systems be established at hazardous and radioactive mixed waste facilities in accordance with the standards of 40 CFR 264, Subpart F or 40 CFR 265, Subpart F.

Order 5400.4, "Comprehensive Environmental Response, Compensation, and Liability Act Program," 10-6-89:

Requires evaluation of geology, hydrology, and hydrogeology when considering remedial alternatives under CERCLA.

\section{Order 5400.5, "Radiation Protection of the Public and the Environment," 2-8-90:}

Requires monitoring of effluents to the environment, including groundwater discharge, to ensure the radiation doses to the public are maintained as low as reasonably achievable, consistent with prescribed dose standards.

\section{Order 5480.1B, "Environment, Safety, and Health Program for DOE Operations," 9-23-86:}

Outlines environmental, safety, and health protection policies and procedures.

\section{Order 5820.2A, "Radioactive Waste Management," 9-26-88:}

Requires disposal sites to be selected, designed, operated, closed, and monitored in a manner which protects groundwater resources. Requires monitoring to assure that the effective dose equivalent to any member of the public does not exceed $25 \mathrm{mrem} / \mathrm{yr}$ from all sources, including groundwater.

\subsection{PENDING REQUIREMENTS}

The lack of EPA or TDEC regulatory standards or DOE order reference concentrations for radionuclides in groundwater led the DOE to draft and propose "Radiation Protection of the Public and Environment" (10 CFR 834). Once final, these regulations will dictate, in general terms, that site GWPPs incorporate (or establish) monitoring measures necessary to protect groundwater resources from radiological contamination. These measures are to be included either directly, or by reference, in a Site Environmental Radiological Protection Plan, and are anticipated to include: 
(1) documentation of monitoring the quality and quantity of groundwater; (2) source identification;

(3) contamination potential; (4) preventive and remediation measures; and (5) coordination with appropriate state representatives.

Proposed Rule 1200-4-3-.07, "Draft Groundwater Classification System", is currently being revised by the TDEC. In general, the rule is anticipated to specify four classifications for groundwater: (1) Class A - current or future source of water supply; (2) Class B - current or future source of water supply that, because of contamination, will not support all uses; (3) Class $C$ - not a current or future source of water supply for drinking or other beneficial use; and (4) Class D - groundwater, which flows to the surface of the ground or mixes with surface water. The date of promulgation of this proposed rule has been delayed indefinitely. However, when promulgated, the rule will impact decisions related to development of radiological protection or reference standards and other areas.

Through DOE's Accelerated Orders Reduction effort, certain requirements in DOE Order 5400.1 have been transferred to DOE Order 231.1 (to be issued in 1996) and some requirements have been modified or cancelled. However, current requirements will remain in effect until contract modifications delete references to DOE Order 5400.1 .

\subsection{TECHNICAL GUIDANCE AND OTHER RELEVANT REQUIREMENTS}

Current technical guidance documents and other regulations that are considered during decisionmaking processes are listed in Appendix B and are categorized by the issuing agency or organization. This list is not a comprehensive list of all available technical guidance pertaining to groundwater monitoring. When this GWPP management plan is updated, references to outdated or revised guidance documents will be removed. 


\subsection{Y-12 PLANT GWPP MONITORING STRATEGY}

The following sections outline the overall monitoring strategy for the Y-12 Plant GWPP, which incorporates the technical approach contained in the Comprehensive Groundwater Monitoring Plan for the Y-12 Plant (Geraghty and Miller 1990). Because of changing regulatory requirements and new information obtained on hydrogeologic conditions at the Y-12 Plant, some of the aspects of the Comprehensive Monitoring Plan have been superseded. However, the general administrative monitoring approach and technical framework remain applicable for the Y-12 Plant GWPP. This strategy is comprised of two key elements: (1) an understanding of the groundwater flow and contaminant transport characteristics of the hydrogeologic system at the Y-12 Plant; and (2) implementation of monitoring programs that comply with applicable requirements, yet are tailored to the characteristics of the groundwater flow system. The following section provides a brief description of the hydrogeologic framework at the Y-12 Plant and is followed by a description of the groundwater monitoring programs implemented within this framework.

\subsection{HYDROGEOLOGIC FRAMEWORK}

The purpose of the following discussion is to provide a generalized overview of the complex hydrogeologic system at the Y-12 Plant; it is not intended as a definitive description of hydrogeologic conditions. Numerous papers, articles, and reports have been prepared, which contain more detailed discussions of various aspects of the Y-12 Plant hydrogeology; these documents are maintained as part of the permanent GWPP administrative record as discussed in Section 4.10.

\subsubsection{Site Geology}

The Y-12 Plant is located within the southern part of the Valley and Ridge physiographic province, which is characterized by narrow elongated ridges and valleys that trend in a northeast-southwest direction. The ridges are typically formed on resistant sandstones, siltstones, and siliceous dolostones, whereas the valleys are commonly underlain by less resistant shales and soluble carbonates. Structurally, the Valley and Ridge province is characterized by thrust faults and 
subsidiary faults. Movement along thrust faults in the region towards the northwest has placed older stratigraphic sequences on top of younger ones.

The geology in the Y-12 Plant area is generally characterized by sequences of southeast-dipping, fractured clastic (primarily shale and siltstone) and carbonate (limestone and dolostone) strata of Lower Cambrian to Lower Ordovician age (Figure 3-1). Strike and dip of bedding in the Y-12 Plant area is generally $\mathrm{N} 55^{\circ} \mathrm{E}$ and $45^{\circ} \mathrm{SE}$, respectively.

Bear Creek Valley is underlain by the interbedded limestone and shale formations of the Conasauga Group (Figure 3-1). The Maynardville Limestone, the uppermost formation of the Conasauga Group, subcrops along the axis of Bear Creek Valley at the base of Chestnut Ridge and the underlying formations of the Conasauga Group, (the Nolichucky Shale, Maryville Limestone, Rogersville Shale, Rutledge Limestone, and Pumpkin Valley Shale) subcrop successively to the north toward Pine Ridge (Figure 3-1). Shale and siltstone beds of the underlying Rome Formation form Pine Ridge to the north, and the primarily dolostone strata of the overlying Knox Group form Chestnut Ridge to the south (Figure 3-1).

Bedrock in the Y-12 Plant area is overlain by any of several materials, including alluvium, colluvium, man-made fill, fine-grained residuum from the weathering of the bedrock, saprolite (a transitional mixture of fine residuum and bedrock remnants), and weathered bedrock. In many areas, the saprolite retains primary textural features of the bedrock, including fractures (Solomon et al. 1992). The overall thickness of these materials in Bear Creek Valley is typically less than $40 \mathrm{ft}$ (Geraghty \& Miller, Inc. 1987a).

The most pervasive structural features in the Y-12 Plant area are extensional, hybrid, and shear fractures (Solomon et al. 1992). Three major joint sets are evident in Bear Creek Valley, one that roughly parallels strike and dip of bedding, one steeply dipping set that parallels geologic strike, and one steeply dipping set that trends perpendicular to strike (Dreier et all. 1987). Fracture densities ranging from about 1 to 60 per foot have been observed in rock outcrops near ORNL (Dreier et al. 1987; Sledz and Huff 1981). Most fractures are short, ranging from tenths of an inch to a few feet 


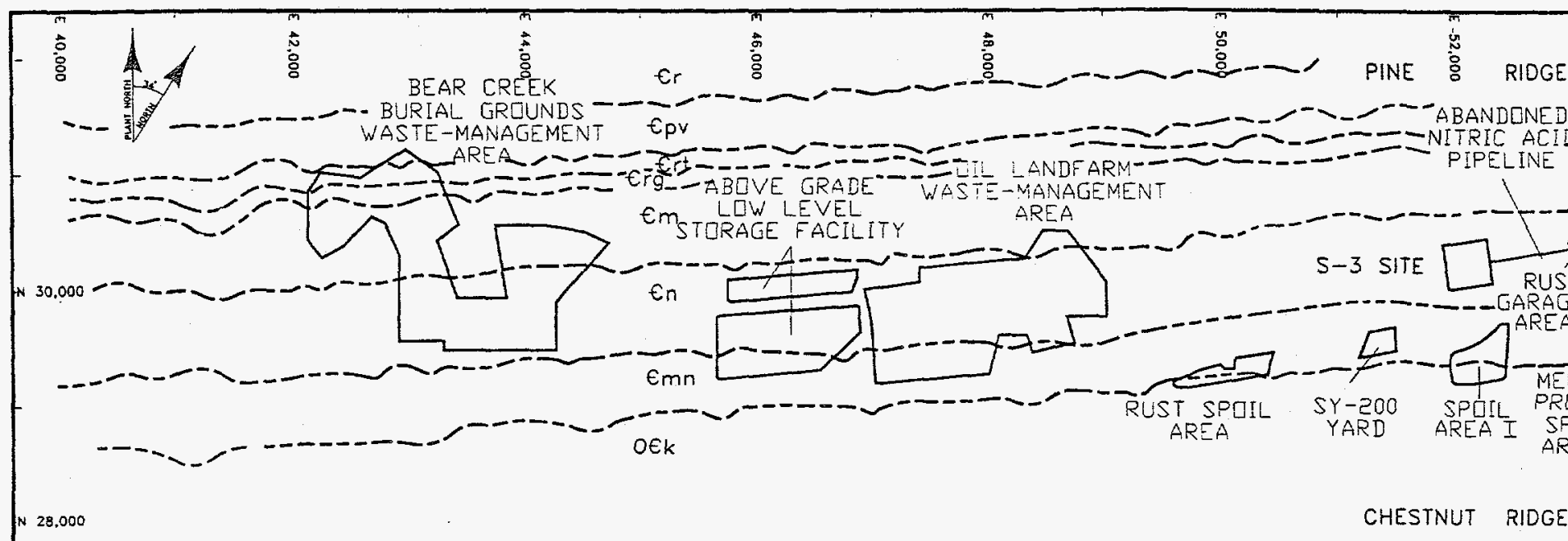

\begin{tabular}{|c|c|c|c|c|c|c|}
\hline \multicolumn{2}{|c|}{ SYSTEM } & \multicolumn{2}{|r|}{$\begin{array}{c}\text { GROUP } \\
\text { (Formation) }\end{array}$} & \multirow{2}{*}{$\begin{array}{c}\text { HYDRO } \\
\text { UNIT } \\
\text { ORR } \\
\text { AQUITARDS }\end{array}$} & \multirow{2}{*}{$\begin{array}{c}\begin{array}{c}\text { MAP } \\
\text { SYMBOL }\end{array} \\
\text { Och }\end{array}$} & \multirow{2}{*}{$\begin{array}{c}\begin{array}{c}\text { THICKNESS } \\
(\mathrm{FT})\end{array} \\
1500-2000\end{array}$} \\
\hline \multirow{3}{*}{ 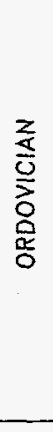 } & $\begin{array}{l}\frac{c}{4} \\
\frac{a}{2} \\
\frac{a}{y}\end{array}$ & & $\begin{array}{l}\text { CHICKAMAUGA } \\
\text { Undifferentiated) }\end{array}$ & & & \\
\hline & 䓂 & \multicolumn{2}{|c|}{$\begin{array}{l}\text { MISSING SECTION } \\
\text { (Suboerial Erosion) }\end{array}$} & & & \\
\hline & 总 & \multicolumn{2}{|r|}{$\underset{\text { (Undifferentiated) }}{\text { KNOX }}$} & \multirow{2}{*}{$\begin{array}{l}\text { KNOX } \\
\text { AQUIFER }\end{array}$} & $o \in k$ & $2500-3000$ \\
\hline \multirow{7}{*}{ 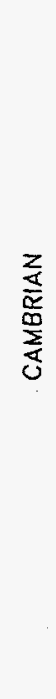 } & & \multirow{6}{*}{ 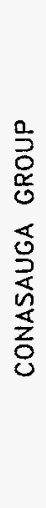 } & $\begin{array}{l}\text { MAYNAROVILLE } \\
\text { LIMESTONE }\end{array}$ & & Emn & $418-450$ \\
\hline & \multirow{5}{*}{$\begin{array}{l}\breve{J} \\
\text { 号 } \\
\bar{\Sigma}\end{array}$} & & $\begin{array}{l}\text { NOLICHUCKY } \\
\text { SHALE }\end{array}$ & \multirow{6}{*}{$\begin{array}{c}\text { ORR } \\
\text { AQUITAROS }\end{array}$} & $\epsilon_{n}$ & $422-550$ \\
\hline & & & $\begin{array}{l}\text { MARYVILLE } \\
\text { LIMESTONE }\end{array}$ & & $€ \mathrm{~m}$ & $346-445$ \\
\hline & & & $\begin{array}{l}\text { ROGERSVILLE } \\
\text { SHALE }\end{array}$ & & Erg & $90-120$ \\
\hline & & & $\begin{array}{l}\text { RUTLEDGE } \\
\text { LIMESTONE }\end{array}$ & & Erit & $90-120$ \\
\hline & & & $\begin{array}{c}\text { PUMPKIN VALLEY } \\
\text { SHALE }\end{array}$ & & epv & $260-320$ \\
\hline & 点 & & ROME & & $\mathrm{Er}$ & $\begin{array}{c}\text { NOT } \\
\text { DETERMINED }\end{array}$ \\
\hline
\end{tabular}




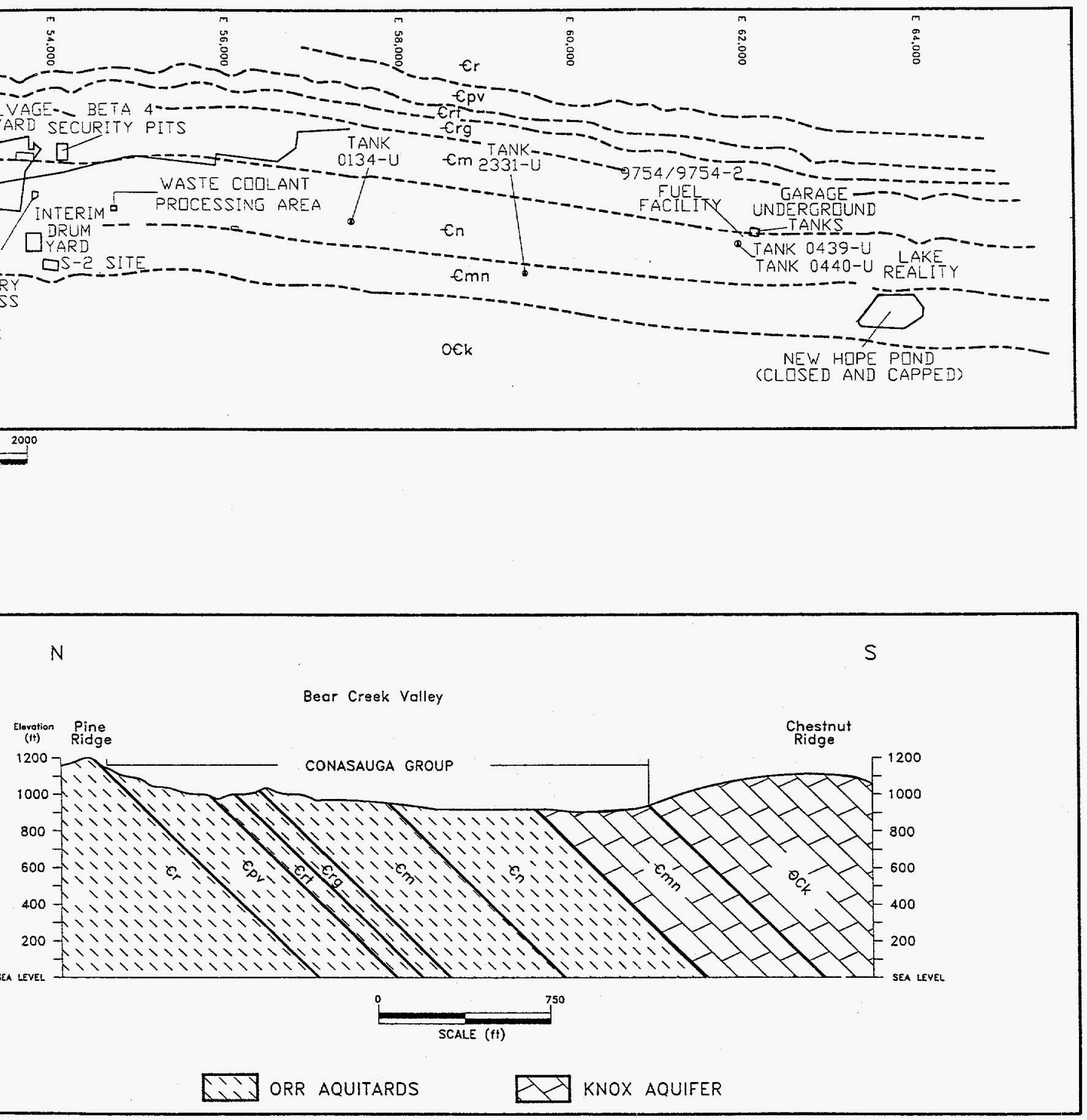

RED FOR:

CKHEED MARTIN

ERGY SYSTEMS, INC.

ARED BY:

$A J A$ TECHNICIAL

SERVICES, INC.

\begin{tabular}{|r|c|}
\hline LOCATION: & $\begin{array}{c}\text { Y-12 PLANT } \\
\text { OAK RIDGE, TN. }\end{array}$ \\
\hline DOC NUMBER: & $96-0005$ \\
\hline DWG ID.: & $96-049$ \\
\hline DATE: & $6-13-96$ \\
\hline
\end{tabular}

\begin{tabular}{c} 
FIGURE 3-1 \\
GEOLOGY OF THE \\
OAK RIDGE Y-12 PLANT \\
\hline
\end{tabular}


in length (Solomon et al. 1992). Within a fracture, groundwater may flow either downdip, laterally, or in both directions. Changes in flow direction may occur at fracture splits, truncations, and intersections and groundwater flow paths may locally resemble stairsteps in both plan and sectional views (Moore 1989). Dissolution of carbonates along fractures, particularly in the Maynardville Limestone and the Knox Group, has produced solution-enlarged features ranging from less than an inch to tens of feet in thickness. Shevenell et al. (1992) report that solution cavities occur throughout the Maynardville Limestone, but most frequently in two of six stratigraphic zones defined by gamma-log signatures and lithologic characteristics, one at the top and one at the bottom of the formation.

\subsubsection{Groundwater Flow System}

In the Y-12 Plant vicinity, the Rome Formation, Conasauga Group, and Knox Group comprise two basic hydrogeologic units: (1) an aquifer, designated the "Knox Aquifer" by the USGS, consisting of the Maynardville Limestone and the overlying formations of the Knox Group, and (2) the aquitard, consisting of the Nolichucky Shale, Maryville Limestone, Rogersville Shale, Rutledge Limestone, Pumpkin Valley Shale of the Conasauga Group, and the Rome Formation (Figure 3-1). The aquifer formations floor the valley along the axis of BCV (Maynardville Limestone) and form Chestnut Ridge, and the aquitard formations are partially exposed successively to the north toward Pine Ridge (Figure 3-1). The aquitard, which underlies the primary contaminant source areas in the Bear Creek Regime and the East Fork Regime, is hydraulically upgradient of the Maynardville Limestone, which functions as a hydrologic drain in BCV and provides the principal avenues for contaminant transport. Groundwater flow in the aquitard is dominated by fractures. Groundwater flow in the aquifer has components of both fracture flow and flow through solution-enlarged cavities and conduits. Flow through the porous rock matrix is negligible in both units; however, this flow component is an important factor regarding contaminant migration because of matrix diffusion processes.

A high conductivity interval near the bedrock/residuum interface (the water table interval) is where nearly all groundwater flow occurs in the aquitard. Below the water table interval, flow is most 
active at depths less than $30 \mathrm{~m}$ (100 ft) below ground surface (bgs); however, contaminants in groundwater more than $60 \mathrm{~m}$ (200 ft) bgs in the Nolichucky Shale clearly indicate permeable flowpaths at depth. Flow occurs in response to precipitation when flowpaths in the residual soils become saturated and rapidly transmit water laterally (stormflow) down slope toward springs and seeps in drainage features, and vertically to the water table interval. Inflow into the water table interval promotes strike-parallel flow toward discharge areas in nearby cross-cutting streams. Only a small percentage of total flow recharges to the deeper bedrock, where upward hydraulic gradients predominate.

Most groundwater flow in the aquifer occurs at shallow depths (i.e., $<100 \mathrm{ft}$ bgs) in an extensively interconnected maze of solution conduits and cavities (karst network). Below the shallow karst network, fractures provide the primary flowpaths. In $\mathrm{BCV}$, groundwater in the aquifer flows primarily along strike, parallel to the axis of the valley. Flow in the shallow karst network is relatively rapid, and during rainfall, occurs as quickflow discharge to Bear Creek. Active groundwater circulation occurs at greater depth than in the aquitard, and in $\mathrm{BCV}$, groundwater from the deeper flow system discharges along major gaining (influent) reaches of Bear Creek channel. These discharge areas are probably related to large-scale structural features (e.g., cross-strike faults) or stratigraphic discontinuities in the Maynardville Limestone. The overall pattern of groundwater flow in the aquifer on Chestnut Ridge is from the recharge areas on the ridge crest toward discharge areas that include the Maynardville Limestone in BCV, and springs and seeps in the crosscutting tributaries along the northern and southern flanks of the ridge.

\subsection{MONITORING PROGRAMS AND APPROACH}

The Y-12 Plant GWPP currently performs groundwater monitoring to meet the objectives of the following drivers: (1) RCRA post-closure requirements, (2) RCRA interim status requirements, (3) TDEC-SWDF requirements, (4) DOE Order 5400.1 surveillance monitoring; (5) DOE Order 5400.1 exit pathway and perimeter monitoring; (6) best management practices (BMPs); and (7) CERCLA programs. Under RCRA post-closure and interim status requirements, detection, assessment and corrective action monitoring are currently performed. Compliance monitoring is not currently required for any RCRA-regulated site. Detection monitoring is also performed at nonhazardous 
solid waste management units in accordance with TDEC Rule 1200-1-7 and operating permits for individual waste management facilities. Monitoring in support of UST programs (release detection, assessment, and corrective action) has been essentially completed at the Y-12 Plant. Currently, only a limited amount of monitoring is conducted in lieu of corrective actions at 4 UST sites. This monitoring is conducted by the Y-12 Plant UST program and is not under the auspices of the Y-12 Plant GWPP. Groundwater monitoring activities are performed in accordance with RCRA monitoring standards and EPA SW-846 protocols, unless other requirements are dictated by governing regulations or approved work plans. These adaptations and modifications to groundwater monitoring activities for specific sites at the Y-12 Plant occur to address hydrogeologic conditions, specific regulatory standards, DOE requirements, and special requirements applicable to CERCLA. Such adaptations are outlined in RI work plans, FS or remedial design efforts, SWDF operating permits or CERCLA records of decisions.

Groundwater monitoring is performed by the Y-12 Plant GWPP within a common technical and administrative framework developed from the experience gained and lessons learned over the past 10 years of monitoring activities at the Y-12 Plant. This technical and administrative framework incorporates the following elements:

- a quarterly sampling frequency (unless otherwise required),

- designated sampling locations and specified sampling sequences,

- standardized monitoring-well design and construction protocols,

- standardized sampling and analysis procedures, and

- $\quad$ standardized suites of analytical parameters.

All monitoring wells, springs, and surface-water stations sampled under the Y-12 Plant GWPP are specified in a single annual Groundwater Sampling and Analysis Plan (see Section 5.4). This plan specifies the sequence in which each well, spring, and surface water station is sampled so that instances of cross-contamination are avoided. The plan denotes sampling frequencies, required parameters, and quality assurance/quality control (QA/QC) requirements. Through the course of the monitoring program each year, addition and removal of sampling locations are documented as 
addenda to this annual plan. Use of this comprehensive planning approach has proven very effective for day-to-day management of the Y-12 Plant GWPP, evaluating current status of monitoring activities, documenting sampling activities, avoiding redundancy and cost tracking..

All wells installed at the Y-12 plant are sampled for at least four consecutive quarters. The quarterly sampling frequency ensures compliance with detection monitoring requirements regarding determination of initial background values for subsequent statistical comparisons, and fulfills the DOE Order 5400.1 requirement to establish baseline water quality conditions for each well. If no contaminants are present in the well, quarterly monitoring is discontinued (unless the well is included in a detection monitoring program).

Early investigations of groundwater quality conditions at the Y-12 Plant employed varying types of monitoring well designs and construction materials, some of which did not comply with regulatory standards and EPA guidance specifications. This has been avoided since 1986 through the establishment of standardized well-construction protocols for two general types of well designs: wells completed with open-hole intervals and wells completed with manufactured well screens. Both well types are completed with the same type of construction materials (e.g., stainless steel well casing). Use of standardized well designs and construction materials minimizes the potential effects on water-sample quality resulting from varying well completion and construction methods. Additionally, standardized inspection and maintenance protocols, and plugging and abandonment procedures (see Sections 5.8 and 5.9 ) are used to ensure that wells are properly maintained and that obsolete or irreparably damaged wells are properly removed.

Groundwater and surface-water analyses are performed by the Y-12 Plant GWPP in accordance with standardized analytical procedures specified by Lockheed Martin Energy Systems Analytical Services Organization QA/QC programs and a laboratory statement of work, which is currently QAP:04-90-0014 (Energy Systems 1991) (Section 5.5) . Sampling procedures comply with requirements of DOE Orders, have been approved by the EPA (Region IV) and the TDEC (EPA 1988), and are based on protocols contained in EPA technical guidance documents and recommendations presented in "Environmental Surveillance Procedures Quality Control Program, 
Martin Marietta Energy Systems, Inc." (Kimbrough et al. 1987). Specialized sampling procedures, such as micro purging methods or other alternative sampling methods necessary for special projects (e.g., to evaluate potential contaminant co-transport by colloidal material) are defined as needed.

Analyses of chemical parameters in samples collected from monitoring wells, springs, and surfacewater stations included in the Y-12 Plant GWPP are based on programmatic or regulatory requirements. Standard groups of chemical parameters (administrative parameter groups) are assigned to each location based on applicable requirements or technical objectives. This approach ensures plant-wide data consistency and, in conjunction with coordinated sampling, enables the Y-12 Plant GWPP to readily track samples and respond quickly to changing drivers. A standard suite of parameters is a baseline for the sampling program that includes contaminants frequently detected in groundwater and surface water at the Y-12 Plant and constituents and parameters needed to evaluate groundwater and surface-water geochemistry. Radiological parameters needed to determine compliance with DOE Orders 5400.5 and 5820.2A, and special analytes required under site-permits or specific regulatory requirements, or parameters to supplement on-going hydrogeologic studies are defined in additional administrative parameter groups. The administrative parameter groups and the lists of analytes for each sampling station are specified in the annual Groundwater Sampling and Analysis Plan. Through the course of the monitoring program each year, the addition and/or removal of analytes for particular sampling locations are documented in addenda to the annual sampling and analysis plan.

\subsubsection{Detection Monitoring}

Detection monitoring at the Y-12 Plant is performed at interim status and permitted RCRA TSD units, and at operating or closed non-hazardous SWDFs. Detection monitoring is performed in accordance with the governing regulations and site-specific permit conditions. Site-specific reports containing the detection monitoring results are prepared and submitted in accordance with applicable RCRA regulations or non-hazardous waste SWDF regulations.

Interim status RCRA detection monitoring was initiated in January 1986 at New Hope Pond and the Chestnut Ridge Security Pits (Table 3-1). Monitoring results showed that contaminants were present 
Table 3-1. RCRA-Regulated Hazardous-Waste Treatment, Storage, and Disposal Sites at the Y-12 Plant

\begin{tabular}{|c|c|c|c|c|c|c|c|c|c|c|c|c|}
\hline \multicolumn{13}{|c|}{ BEAR CREEK REGIME } \\
\hline S-3 Site ${ }^{1}$ & $\begin{array}{l}\text { Monitoring } \\
\text { Programs }\end{array}$ & 1986 & 1987 & 1988 & 1989 & 1990 & 1991 & 1992 & 1993 & 1994 & 1995 & 1996 \\
\hline RCRA Interim Status & Detection & - & - & - & - & - & - & - & - & - & - & - \\
\hline \multirow{4}{*}{$\begin{array}{l}\text { RCRA Operating/Post- } \\
\text { Closure Permit }\end{array}$} & Assessment & t & 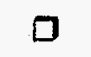 & $\square$ & $\square$ & $\square$ & $\square$ & $\square$ & - & - & - & - \\
\hline & Detection & $n-$ & - & - & - & - & - & - & - & - & - & - \\
\hline & Compliance & e - & - & - & - & - & - & - & - & - & - & - \\
\hline & Corrective Action & $n-$ & - & - & - & - & - & - & $\square$ & ם & a & $\square$ \\
\hline \multirow{3}{*}{ RCRA Interim Status } & $\begin{array}{c}\text { Monitoring } \\
\text { Programs }\end{array}$ & 1986 & 1987 & 1988 & 1989 & 1990 & 1991 & 1992 & 1993 & 1994 & 1995 & 1996 \\
\hline & Detection & - & - & - & - & - & - & - & - & - & - & - \\
\hline & Assessment & $\square$ & $\square$ & $\square$ & $\square$ & ם & $\square$ & $\square$ & $\square$ & $\square$ & - & - \\
\hline \multirow{3}{*}{$\begin{array}{l}\text { RCRA Operating/Post- } \\
\text { Closure Permit }\end{array}$} & Detection & $n-$ & - & - & - & - & - & - & - & - & - & - \\
\hline & Compliance & e - & - & - & - & - & - & - & - & - & - & - \\
\hline & Corrective Action & $n-$ & - & - & - & - & - & - & - & - & $\square$ & $\square$ \\
\hline $\begin{array}{l}\text { Bear Creek } \\
\text { Burial Grounds WMA }\end{array}$ & $\begin{array}{c}\text { Monitoring } \\
\text { Programs }\end{array}$ & 1986 & 1987 & 1988 & 1989 & 1990 & 1991 & 1992 & 1993 & 1994 & 1995 & 1996 \\
\hline RCRA Interim Status & Detection & - & - & - & - & - & - & - & - & - & - & - \\
\hline \multirow{4}{*}{$\begin{array}{l}\text { RCRA Operating/Post- } \\
\text { Closure Permit }\end{array}$} & Assessment & $\square$ & $\square$ & $\square$ & $\square$ & $\square$ & $\square$ & $\square$ & $\square$ & $\square$ & - & - \\
\hline & Detection & $n-$ & - & - & - & - & - & - & - & - & - & - \\
\hline & Compliance & e - & - & - & - & - & - & - & - & - & - & - \\
\hline & Corrective Action & $n-$ & - & - & - & - & - & - & - & - & $\square$ & $\boldsymbol{\square}$ \\
\hline \multicolumn{13}{|c|}{ EAST FORK REGIME } \\
\hline New Hope Pond ${ }^{4}$ & $\begin{array}{l}\text { Monitoring } \\
\text { Programs }\end{array}$ & 1986 & 1987 & 1988 & 1989 & 1990 & 1991 & 1992 & 1993 & 1994 & 1995 & 1996 \\
\hline \multirow[t]{3}{*}{ RCRA Interim Status } & Detection & $\square$ & $\square$ & - & - & - & - & - & - & - & - & - \\
\hline & Assessment & - & - & $\square$ & $\square$ & $\square$ & $\square$ & $\square$ & ם & ט & $\square$ & a \\
\hline & Detection & $n-$ & - & - & - & - & - & - & - & - & - & - \\
\hline \multirow[t]{2}{*}{$\begin{array}{l}\text { RCRA Operating/Post- } \\
\text { Closure Permit }\end{array}$} & Compliance & e - & - & - & - & - & - & - & - & - & - & - \\
\hline & Corrective Action & $n-$ & - & - & - & - & - & - & - & - & - & TBD \\
\hline
\end{tabular}


Table 3-1. (cont'd)

\section{CHESTNUT RIDGE REGIME}

\begin{tabular}{|c|c|c|c|c|c|c|c|c|c|c|c|c|}
\hline $\begin{array}{l}\text { Chestnut Ridge } \\
\text { Sediment Disposal } \\
\text { Basin }^{5}\end{array}$ & $\begin{array}{l}\text { Monitoring } \\
\text { Programs }\end{array}$ & 1986 & 1987 & 1988 & 1989 & 1990 & 1991 & 1992 & 1993 & 1994 & 1995 & 1996 \\
\hline RCRA Interim Status & Detection & $\square$ & $\square$ & $\square$ & $\square$ & $\square$ & $\square$ & $\square$ & $\square$ & $\mathbf{0}$ & - & - \\
\hline \multirow{4}{*}{$\begin{array}{l}\text { RCRA Operating/Post- } \\
\text { Closure Permit }\end{array}$} & Assessment & - & - & - & - & - & - & - & - & - & - & - \\
\hline & Detection & $1-$ & - & - & - & - & - & - & - & - & $\square$ & $\square$ \\
\hline & Compliance & - & - & - & - & - & - & - & - & - & - & - \\
\hline & Corrective Action & - & - & - & - & - & - & - & - & - & - & - \\
\hline $\begin{array}{l}\text { Chestnut Ridge } \\
\text { Security Pits }\end{array}$ & $\begin{array}{l}\text { Monitoring } \\
\text { Programs }\end{array}$ & 1986 & 1987 & 1988 & 1989 & 1990 & 1991 & 1992 & 1993 & 1994 & 1995 & 1996 \\
\hline \multirow[t]{2}{*}{ RCRA Interim Status } & Detection & $\square$ & $\square$ & - & - & - & - & - & - & - & - & - \\
\hline & Assessment & - & - & ם & $\square$ & $\square$ & $\square$ & $\square$ & ם & ם & $\square$ & - \\
\hline \multirow{3}{*}{$\begin{array}{l}\text { RCRA Operating/Post- } \\
\text { Closure Permit }\end{array}$} & Detection & - & - & - & - & - & - & - & - & - & - & - \\
\hline & Compliance & $e-$ & - & - & - & - & - & - & - & - & - & - \\
\hline & Corrective Action & - & - & - & - & - & - & - & - & - & - & $\square$ \\
\hline $\begin{array}{l}\text { East Chestnut Ridge } \\
\text { Waste Pile }^{7}\end{array}$ & $\begin{array}{c}\text { Monitoring } \\
\text { Programs }\end{array}$ & 1986 & 1987 & 1988 & 1989 & 1990 & 1991 & 1992 & 1993 & 1994 & 1995 & 1996 \\
\hline \multirow[t]{2}{*}{ RCRA Interim Status } & Detection & - & - & - & - & - & - & - & - & - & - & - \\
\hline & Assessment & - & - & - & - & - & - & - & - & - & - & - \\
\hline \multirow{3}{*}{$\begin{array}{l}\text { RCRA Operating/Post- } \\
\text { Closure Permit }\end{array}$} & Detection & - & - & - & - & - & - & - & - & - & - & - \\
\hline & Compliance & e - & - & - & - & - & - & - & - & - & - & - \\
\hline & Corrective Action & $1-$ & - & - & - & - & - & - & - & - & - & - \\
\hline Kerr Hollow Quarry ${ }^{8}$ & $\begin{array}{l}\text { Monitoring } \\
\text { Programs }\end{array}$ & 1986 & 1987 & 1988 & 1989 & 1990 & 1991 & 1992 & 1993 & 1994 & 1995 & 1996 \\
\hline \multirow[t]{2}{*}{ RCRA Interim Status } & Detection & $\square$ & $\square$ & 口 & $\square$ & $\square$ & $\square$ & $\square$ & $\square$ & $\square$ & ( & $\square$ \\
\hline & Assessment & - & - & - & - & - & - & - & - & - & - & - \\
\hline \multirow{3}{*}{$\begin{array}{l}\text { RCRA Operating/Post- } \\
\text { Closure Permit }\end{array}$} & Detection & $a-$ & - & - & - & - & - & - & - & - & - & $\mathrm{TBD}$ \\
\hline & Compliance & $e-$ & - & - & - & - & - & - & - & - & - & - \\
\hline & Corrective Action & - & - & - & - & - & - & - & - & - & - & - \\
\hline
\end{tabular}


Table 3-1. (cont'd)

Notes:

1. Interim status GWQAP prepared in December 1986. Interim status assessment monitoring data reported in site-specific GWQRs 1986 - 1988; reported in GWQR for Bear Creek Regime 1990-1993. Post-closure RCRA corrective action monitoring initiated October 1993.

2. Interim status GWQAP prepared in December 1986. Interim status assessment monitoring data reported in site-specific GWQRs 1986 - 1988; reported in GWQR for Bear Creek Regime 1990-1995. Post-closure RCRA corrective action monitoring initiated June 1995.

3. Interim status GWQAP prepared in December 1986. Interim status assessment monitoring data reported in site-specific GWQRs 1986 - 1988; reported in GWQR for Bear Creek Regime 1990-1995. Post-closure RCRA corrective action monitoring initiated September 1995.

4. Interim status detection monitoring initiated January 1986. GWQAP prepared in January 1988. Interim status assessment monitoring data reported in site-specific GWQR 19881989; reported in GWQR for East Fork Regime 1990-1995. Post-closure RCRA groundwater monitoring program currently under negotiation with TDEC, post-closure permit pending.

5. Interim status detection monitoring initiated January 1986. Monitoring data reported in sitespecific reports: also included in GWQR for Chestnut Ridge Regime since 1991. RCRA permit-required detection monitoring initiated September 1995.

6. Interim status detection monitoring initiated January 1986. GWQAP prepared in January 1988. Interim status assessment monitoring data reported in site-specific GWQRs 1988 1990; reported in GWQR for Chestnut Ridge Regime 1991-present. Post-closure RCRA corrective action monitoring program initiated March 1996.

7. Lined waste pile exempt from RCRA interim status and permit-required groundwater monitoring.

8. Interim status detection monitoring initiated January 1986. Monitoring data reported in sitespecific reports; also included in GWQR for Chestnut Ridge Regime since 1991. RCRA post-closure monitoring program under negotiation with TDEC; post-closure permit pending. 
in the groundwater at both sites, and RCRA interim status assessment monitoring was subsequently initiated at each site in January 1988.

Currently, RCRA interim status detection monitoring is performed at Kerr Hollow Quarry and the Chestnut Ridge Sediment Disposal Basin (Table 3-1). Quarterly monitoring at both sites to establish baseline water quality conditions began in January 1986, and wells at the sites have been sampled at least semi-annually thereafter. Statistical analyses of the monitoring data are performed and reported to the TDEC in accordance with RCRA interim status detection monitoring regulations. In 1991, a false positive demonstration for both of these sites was submitted to and approved by the TDEC (Lagan 1992). This demonstration confirmed that, in calendar year 1991, the statistically significant changes in total organic carbon, total organic halide, $\mathrm{pH}$, and specific conductance indicated by the required t-test methodology did not represent contaminant releases from either site (McMahon and Mercier 1992). Statistically significant changes in these parameters identified in subsequent analyses also were shown to be false positives consistent with the 1991 data demonstration.

Because of these difficulties with false-positive statistical increases at the Chestnut Ridge Sediment Disposal Basin, the Y-12 Plant GWPP has used an alternative statistical analysis procedure, based on a method presented in "Statistical Analysis of Groundwater Monitoring Data at RCRA Facilities Interim Final Guidance" (EPA 1989), to supplement the t-test procedure required by the TDEC regulations. This alternative method utilizes a group of site-specific indicator parameters (trace metals), and has proven less prone to producing false-positive statistical increases.

Beginning in September 1995, detection monitoring at the Chestnut Ridge Sediment Disposal Basin was performed in accordance with the requirements for permitted TSD facilities. A RCRA Part B post-closure permit for the Chestnut Ridge Sediment Disposal Basin was issued by the TDEC in September 1995. Kerr Hollow Quarry has been closed under RCRA, but interim status detection monitoring has continued pending final negotiation of the RCRA post-closure permit for the site. 
Detection monitoring in accordance with the requirements contained in the TDEC solid waste management regulations is currently performed at Centralized Sanitary Landfill II, Industrial Landfills V and VI, and Construction/Demolition Landfills VI and VII. Monitoring at each of these sites is performed in accordance with the TDEC regulations and conditions specified in the permit for each site.

\subsubsection{Assessment Monitoring}

An expanded version of RCRA interim status assessment monitoring has been the principal Y-12 Plant GWPP monitoring program used to obtain the data needed to determine the extent of groundwater contamination and the rate of contaminant migration at the Y-12 Plant. This expanded assessment monitoring program was designed to generate data needed to support the Y-12 Plant ERP and address regulatory requirements for environmental assessment monitoring at petroleum USTs and assessment monitoring at non-hazardous SWDFs.

Assessment monitoring has been conducted on a broad scale for each of three distinct hydrogeologic regimes into which the groundwater flow system at the Y-12 Plant has been divided: (1) the Bear Creek regime encompassing much of Bear Creek Valley west of the Y-12 Plant; (2) the Upper East Fork Poplar Creek (East Fork) regime encompassing the Y-12 Plant complex and the upper reaches of East Fork Poplar Creek; and (3) the Chestnut Ridge regime located on Chestnut Ridge south of the Y-12 Plant (Figure 3-2). The programmatic advantages and technical justification for subdividing the groundwater system into distinct hydrogeologic regimes are provided in the Comprehensive Monitoring Plan (Geraghty \& Miller, Inc. 1990).

Monitoring results have been submitted annually to the TDEC in GWQRs (formerly GWQARs) prepared for each hydrogeologic regime. These reports are completed in two parts. Part 1 contains the monitoring data obtained during the calendar year. Part 2 contains detailed evaluation and interpretation of the data, and specific recommendations for additional well installation, sampling locations, hydrologic studies, and other activities needed to obtain specific hydrogeologic information or fill existing data gaps. 


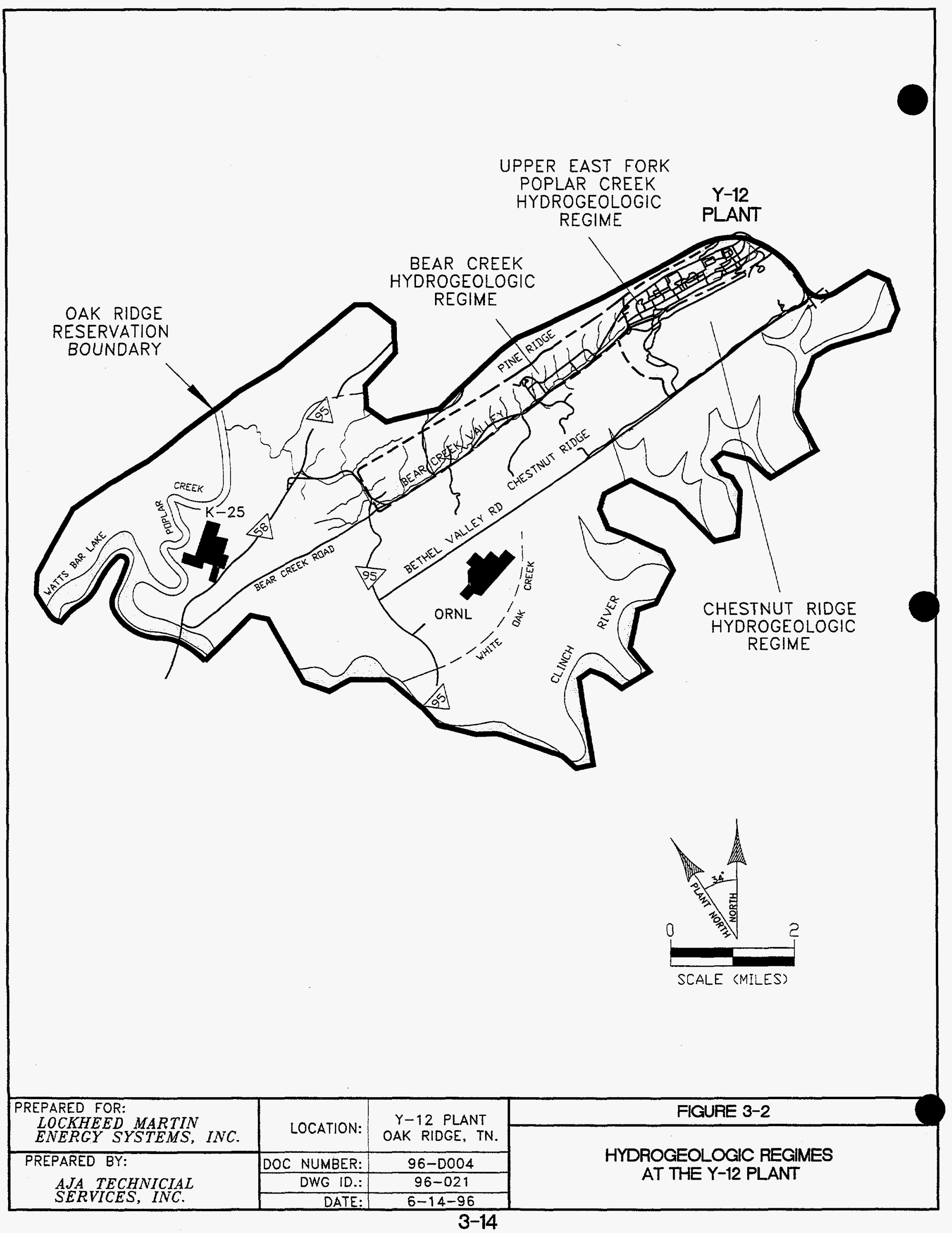




\section{Bear Creek Regime}

The integrated assessment monitoring program for the Bear Creek hydrogeologic regime evolved from site-specific assessment programs initiated at the three RCRA TSD units (S-3 Ponds, Oil Landfarm Waste Management Area, and Bear Creek Burial Grounds Waste Management Area). Assessment monitoring was initiated at each of these sites in January 1986 in accordance with respective GWQAPs submitted to the TDEC (Geraghty \& Miller, Inc. 1987b, 1987c, 1987d) (Table 3-1). In 1989, these site-specific assessment monitoring programs were combined and expanded to incorporate RFI monitoring efforts in progress at three SWMUs (Rust Spoil Area, Spoil Area I, and SY-200 Yard).

Implementation of the integrated assessment monitoring program in the Bear Creek regime over the past several years provided the bulk of the groundwater data used for the CERCLA RI for the Bear Creek CA. These data, along with other data collected for the specific purposes of the RI, were used to develop conceptual models for groundwater flow and contaminant transport (SAIC, Inc. 1996).

A RCRA post-closure permit for the S-3 Site was issued by the TDEC in September 1993, and RCRA corrective action monitoring was initiated in October 1993. This post-closure permit was subsequently expanded to include the Oil Landfarm WMA and Bear Creek Burial Grounds WMA, and corrective action monitoring was initiated for these two sites in June 1995, and September 1995, respectively.

Monitoring of groundwater contaminant exit pathways is performed to provide data on the quality of water exiting the Bear Creek regime through the Maynardville Limestone. This program was supported by an extensive investigation of the Maynardville Limestone in the Bear Creek and East Fork regimes (Shevenell et al. 1992). The initial phase of the investigation involved installation of monitoring wells at various depths along several transects across the formation. All wells installed during this investigation, in addition to several springs that discharge to Bear Creek and several sampling stations located along the creek, are currently used for exit pathway monitoring purposes. In addition, surveillance of contaminant plume boundaries is also conducted in selected locations along geologic strike of waste management units. 


\section{East Fork Regime}

An integrated contamination assessment monitoring program initiated in 1989 is still ongoing for the East Fork regime. This program incorporates: (1) RCRA-interim status assessment monitoring at New Hope Pond "triggered" from detection monitoring in 1987 and performed in accordance with a GWQAP submitted to the TDEC in January 1988 (Geraghty \& Miller, Inc. 1987e) (Table 3-1); (2) contamination assessment monitoring at several petroleum USTs within the Plant complex; (3) RFI monitoring at several RCRA SWMUs located near the west end of the Y-12 Plant; (4) monitoring wells located east of the hydrogeologic divide between the East Fork and Bear Creek regimes used for the RCRA assessment monitoring program at the S-3 Ponds; and (5) DOE Order 5400.1 surveillance monitoring wells installed in a pre-defined grid pattern (Grid Program) used to facilitate delineation of contaminant plume boundaries in the regime. Integration of these groundwater monitoring efforts was first proposed in the Comprehensive Monitoring Plan (Geraghty \& Miller, Inc. 1990). As with the Bear Creek CA, this integrated assessment monitoring program is expected to provide most of the groundwater quality data needed for the CERCLA RI/FS for the East Fork CA.

Assessment monitoring in the East Fork regime also includes monitoring wells installed under the Exit Pathway Program. Fewer exit pathway wells are installed in this regime than in the Bear Creek regime because of the access problems within the Y-12 Plant. Surface-water sampling is not performed as part of the Exit Pathway Program in the East Fork regime because extensive sampling of the water in the creek is already performed as a best-management practice and as required under National Pollution Discharge Elimination System permits.

\section{Chestnut Ridge Regime}

Assessment monitoring in the Chestnut Ridge regime was performed only at the Chestnut Ridge Security Pits (Chestnut Ridge OU 1). Assessment monitoring at the site was initiated in 1988 (Table 3-1) in response to statistically significant increases in monitored parameters identified during detection monitoring in 1986, and performed in accordance with a GWQAP submitted to the TDEC in 1988 (Geraghty \& Miller, Inc. 1988a). Contaminant plume boundaries have been essentially established, but the dynamics of the karst flow system underlying Chestnut Ridge may preclude a 
complete assessment of the extent of contamination from the site. Moreover, several dye-tracer tests have failed to conclusively identify the discharge areas for the contaminated groundwater at the Chestnut Ridge Security Pits. Efforts to identify these discharge areas may be an objective of the RI/FS planned for Chestnut Ridge CA. Assessment monitoring in the Chestnut Ridge Security Pits was discontinued in March 1996 in lieu of the RCRA corrective action monitoring program specified in the RCRA post-closure permit for the site.

\subsubsection{DOE Order 5400.1 Surveillance Monitoring}

Surveillance monitoring at the Y-12 Plant is required by DOE Order 5400.1 , and is performed in accordance with a monitoring strategy presented in "Environmental Monitoring Plan for the Oak Ridge Reservation" (DOE 1995). Additionally, groundwater monitoring activities performed at the Y-12 Plant as a best-management-practice or in support of special hydrogeologic studies are considered part of the surveillance monitoring program. All groundwater samples collected during surveillance monitoring at the Y-12 Plant are analyzed for the standard suite of analytical parameters.

\subsubsection{DOE Order 5400.1 Exit Pathway and Perimeter Monitoring}

The perimeter monitoring well network at the Y-12 Plant consists of 12 wells located in the Bear Creek and East Fork regimes. No perimeter monitor wells are located in the Chestnut Ridge regime; perimeter monitoring in this regime primarily involves monitoring of springs discharging to the surface-drainage system on Chestnut Ridge.

Three of the perimeter wells are located north of the Y-12 Plant where East Fork Poplar Creek passes through a gap in Pine Ridge, and are used to monitor the quality of shallow groundwater exiting the Y-12 Plant area through the gap in the ridge. The 9 remaining perimeter wells are located along two transects; 3 wells in the East Fork Regime located along a transect near the east end of the Y-12 Plant, and 6 wells in the Bear Creek regime located along a transect west of the Bear Creek Burial Grounds. The eastern transect also includes a core hole equipped with a multi-port sampling system used to obtain groundwater samples from a variety of depths. These perimeter wells monitor groundwater quality conditions in the Maynardville Limestone, which is the principal avenue for 
subsurface contaminant migration in the Bear Creek and East Fork regimes. All of these wells were installed as part of the investigation of the Maynardville Limestone performed in support of the Exit Pathway Program (Shevenell et al. 1992). In addition to the wells that comprise the formal perimeter network, wells, springs, and surface water stations in Beer Creek Valley that monitor potential contaminant transport pathways (or discharge points) are sampled on a semiannual or quarterly basis. These monitoring locations satisfy the DOE Order 5400.1 requirement to monitor potential exit pathways whereby contaminants could be migrating off of the site.

\subsubsection{Best Management Practice Monitoring}

Groundwater monitoring is performed as a best management practice at selected non-regulated or exempt waste-management sites. For instance, groundwater monitoring has been performed at the East Chestnut Ridge Waste Pile since September 1987, although this interim status RCRA TSD facility was constructed with secondary containment and is exempt from requirements for groundwater monitoring.

\subsubsection{CERCLA Programs}

Groundwater monitoring in support of CERCLA activities may be subdivided into two categories: monitoring to support RI/FS activities and monitoring to support CERCLA RODs. Funding for RI/FS activities is obtained from separate accounts for each specific CERCLA OU, and only those sampling locations that directly benefit a specific OU are funded. Funding to monitor locations off of the Oak Ridge Reservation in Union Valley is currently provided by the Y-12 Plant ER Program for activities associated with the Union Valley Interim Study.

Monitoring to support RCRA post-closure activities and RODs is done through the Y-12 ER Program Surveillance and Maintenance Program. Currently, monitoring at the United Nuclear Site and Kerr Hollow Quarry is funded by the Y-12 Plant ER Surveillance and Maintenance Program to support post-closure requirements of the RODs for these sites. Groundwater monitoring to comply with terms of the current RCRA post-closure permit modifications (Table 3-1) is also funded through the Surveillance and Maintenance Program. 


\subsection{Y-12 PLANT GWPP ORGANIZATION, ROLES, AND RESPONSIBILITIES}

The organization roles and responsibilities of the various portions of the Y-12 Plant GWPP are presented in this section. Section 5.0 summarizes the Y-12 Plant GWPP element plans that are used to implement the organization discussed in this section.

\subsection{ORGANIZATION}

Responsibility for the Y-12 Plant GWPP lies with the GWPP Manager, who is a member of the Environmental Management Department (EMD) within the HSEA Organization of the Y-12 Plant. Figure 4-1 shows the line organization from Plant Manager to GWPP Manager.

The Y-12 Plant GWPP is a multielement, multidisciplinary, matrix organization with the GWPP Manager acting as the central coordinator and primary interface with other programs. The Y-12 Plant GWPP has a direct technical and administrative interface with the Energy Systems Groundwater Program Office (GWPO), which is tasked to provide overall implementation of the ORR Groundwater Program (Energy Systems 1993a). Each element of the program has specified functions, which are implemented by the designated element project manager/supervisor. The GWPP is responsible for the following:

- Implementing the comprehensive groundwater monitoring program and providing groundwater data management from field acquisition through input to the Y-12 GWPP Groundwater Measurements SAS data sets and coordinating transfer of data to the Oak Ridge Environmental Information System (OREIS).

- Reporting as required by RCRA and DOE orders and providing data, documentation, and analyses for input into CERCLA documents as requested by the $\mathrm{Y}-12 \mathrm{ERP}$.

- Developing procedures or utilizing existing procedures, as appropriate.

- Maintaining a formal records management system to capture sample chains of custody, analytical packages, data verification/validation documentation, RCRA required records, and technical information.

- $\quad$ Serving as the Y-12 Plant groundwater interface with the K-25 Analytical Services Organization (ASO), Energy Systems Analytical Project Office (APO), and GWPO. 


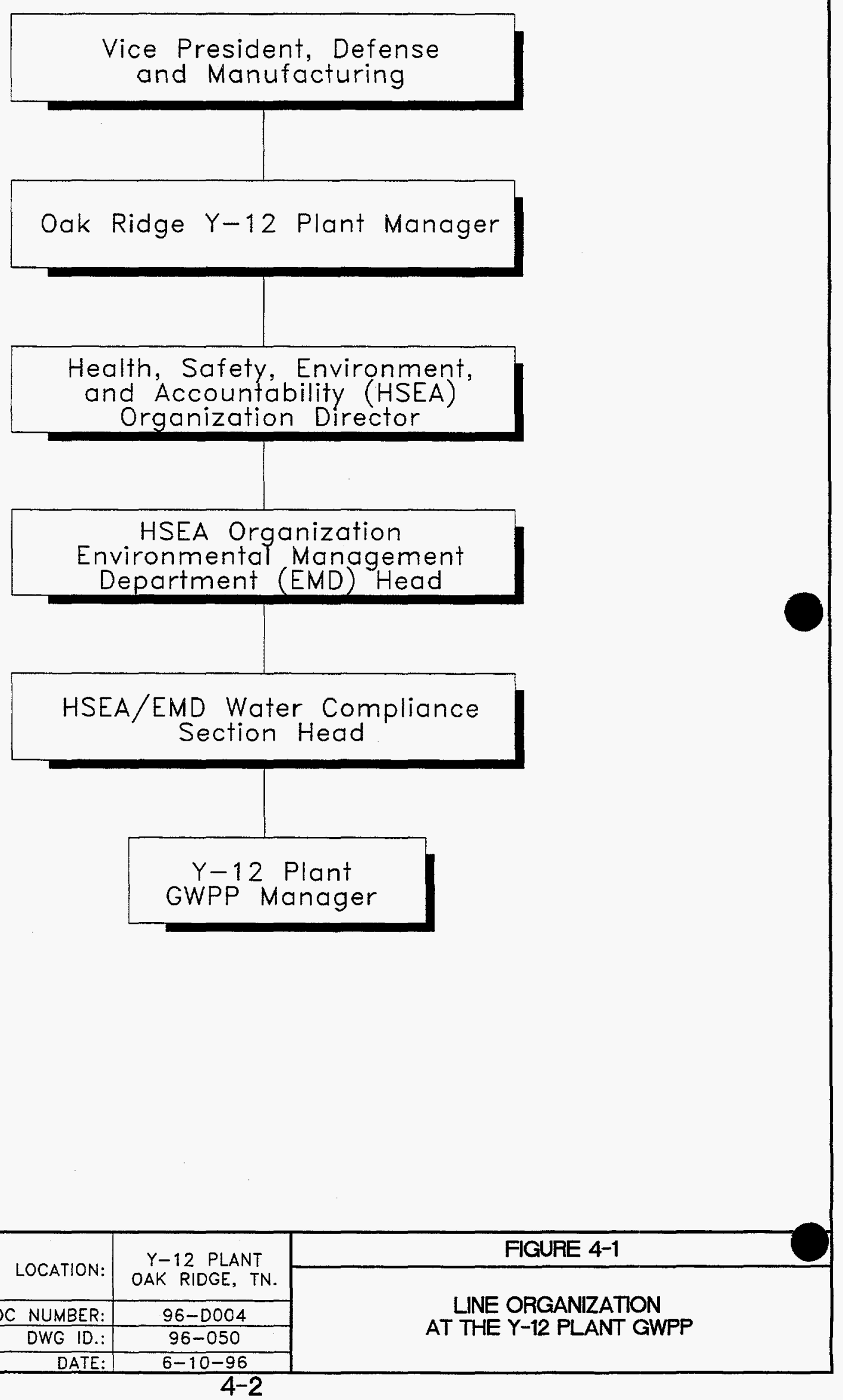


- Maintain and inspecting the Y-12 Plant groundwater monitoring well network within the Y-12 Plant area of responsibility.

- Serving as a technical resource and service resource to customer organizations..

Figure 4-2 depicts the functional and matrix organization of the Y-12 Plant GWPP. The following subsections broadly define the major roles and responsibilities of each element of the GWPP. Additional responsibilities of personnel within each GWPP element are discussed in Section 5.0 as related to element project plans.

\subsection{PROGRAM MANAGEMENT}

Management of the Y-12 Plant GWPP is the responsibility of the Water Compliance Section of the EMD within the HSEA Organization. Within the GWPP three positions, the Program Manager, the Technical Manager and the Sampling and Analysis Coordinator have primary responsibility for implementation of the GWPP.

\subsubsection{GWPP Manager}

Primary responsibilities of the GWPP Manager include:

- Responsible for the Y-12 Plant GWPP Management Plan and associated element plans and implementation of the Y-12 Plant Comprehensive Monitoring Program.

- Primary interface with GWPO and ensuring that implementation of the Y-12 Plant GWPP is consistent with other DOE-Oak Ridge facilities.

- Serving as a single point of contact for technical resources to customer organizations and DOE.

- $\quad$ Responsible for all programmatic and planning requirements relative to the Defense Programs funded activities, and incorporating Y-12 Plant ER Program and Waste Management Program funded activities into the overall groundwater program planning.

- Meeting all classification and security requirements of groundwater data.

- Defining well drilling, plugging and abandonment, and maintenance requirements.

- Interfacing with other plant organizations. 


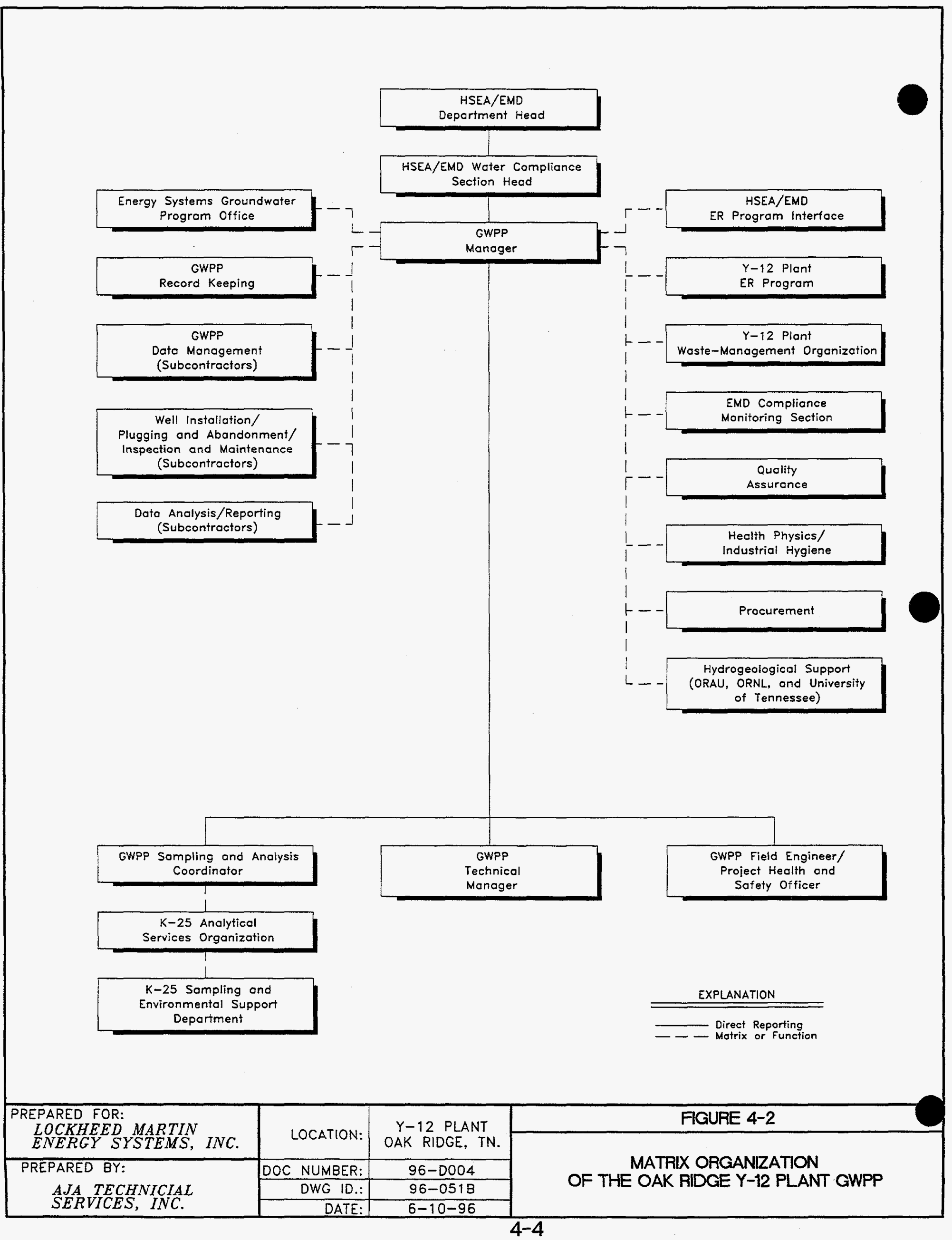


The GWPP Manager also serves as the primary contact between the Y-12 Plant GWPP matrix organizations and DOE, regulatory agencies (through Y-12 Plant Management and DOE), and other Energy Systems programs as related to Defense Programs funded activities. The GWPP Manager is responsible for maintaining the quality of the GWPP and is ultimately responsible for the success of the program as a whole and each of the individual elements.

\subsubsection{GWPP Technical Manager}

The GWPP Technical Manager reports to the GWPP Manager and has primary responsibility to:

- Review hydrogeologic assessments and provide recommendations.

- Review well installation specifications and ensure that groundwater monitoring wells are installed according to specifications.

- Assist with defining well installation and plugging and abandonment programs.

- Execution of TDEC SWDF detection monitoring requirements.

- Coordinate technical field projects.

\subsubsection{GWPP Sampling and Analysis Coordinator}

The GWPP Sampling and Analysis Coordinator also reports to the GWPP Manager and has primary responsibility for the following:

- Develop and update sampling schedules, bottle lists, well sampling location maps, and purge water containment requirements on a quarterly basis and as required by additions or deletions to the monitoring network.

- Primary point of contact and tracks and coordinates sampling activities for the sampling personnel.

- $\quad$ Primary point of contact and coordinates purge water containment, treatment, and disposal activities with appropriate EMD and Waste Management Organization personnel.

- Primary point of contact with the ASO representatives to ensure that analytical methods, analytical parameters, and data reporting schedules are completed as specified.

- Conducts quarterly assessments of sampling activities against standard operating procedures. 


\subsection{HEALTH AND SAFETY}

Health and safety is the responsibility of each task project manager with support from the Industrial Hygiene and Health Physics Departments within the HSEA Organization of the Y-12 Plant. Individual health and safety plans exist or are being developed for specific tasks within the Y-12 Plant GWPP (Section 5.1).

\subsection{QUALITY ASSURANCE}

Quality assurance for the Y-12 Plant GWPP is the responsibility of the GWPP Manager and the EMD QA Coordinator. Primary responsibilities of the QA Coordinator are to:

- $\quad$ Aid in the preparation and implementation of Quality Assurance Plans (QAPs) (Section 5.2).

- $\quad$ Provide the GWPP staff with assistance in meeting programmatic or element quality objectives.

- Use an audit tracking system to monitor progress in addressing program deficiencies which have been identified internally or externally.

- Provide assistance with quality reviews of programs, projects, or documents.

\subsection{PROCUREMENT}

Procurement of the necessary subcontract drilling services for the Y-12 Plant GWPP is conducted through the Energy Systems GWPO. Releases for specific drilling projects are handled directly by the GWPP Technical Manager. The GWPO assumes responsibility to:

- Consult with the GWPP Manager and the GWPP Technical Manager to obtain technical and operational requirements and specifications.

- Prepare documents to obtain subcontractor services.

- Work with Energy Systems Procurement Division to procure subcontractor services.

- Provide assistance for subcontract administration.

Procurement of other services and materials for the Y-12 Plant GWPP are handled by direct interaction with the Energy Systems Procurement Division with support from the HSEA 
Organization Finance Officer. All procurements for the Y-12 Plant GWPP are conducted following established governmental and Energy Systems procedures and practices.

\subsection{ENGINEERING AND WELL INSTALLATION}

Engineering services for the Y-12 Plant GWPP are coordinated through the EMD Project Engineer (PJ), who is a member of the Energy Systems Engineering Division. Primary responsibilities of the PJ are, upon request from the GWPP Field Projects Manager, establishment of Engineering Service Orders for subcontractor services and any required engineering support for drilling services and well installations, such as surveying services. The GWPP Field Engineer Project Health and Safety Officer has the responsibility to acquire necessary permits for drilling and well installations, such as excavation, welding, and work safety permits. In addition, the Field Engineer coordinates on-site supervision of drilling and well installation subcontractors, and functions as a project health and safety officer for drilling or geotechnical field activities.

\subsection{SAMPLING AND ANALYSIS}

Sampling and analysis of groundwater for the Y-12 Plant GWPP are coordinated through the GWPP Sampling and Analysis Coordinator, whose responsibilities are described in Section 4.2.3. The Sampling and Analysis Coordinator works directly with a Project Manager assigned by the ASO and with the K-25 SESD Manager. In addition, the Sampling and Analysis Coordinator works with the $\mathrm{APO}$, who has the responsibility to procure and coordinate external subcontract laboratories when required. The GWPP Manager and ASO Project Manager assist the Sampling and Analysis Coordinator with execution of the Comprehensive Monitoring Program. Primary responsibilities of the GWPP Manager include:

- Assistance with preparation and implementation of the annual Sampling and Analysis Plan and addenda to the plan.

- Assurance that established sampling procedures are followed.

- Defining monitoring requirements to be included in the annual Sampling and Analysis Plan. 
Primary responsibilities of the ASO Project Manager include:

- $\quad$ Serving as the interface with the APO as required.

- Assisting with the preparation and implementation of the annual Sampling and Analysis Plan and addenda to the plan.

- Assuring established analytical procedures are followed.

- Consulting with analytical personnel in development and incorporation of new analytical procedures.

- Interaction with the GWPP data management subcontractor to provide electronic data deliverables and help prepare a bi-weekly sample tracking report.

The ASO project manager interacts directly with the Sampling Coordinator, and coordinates all laboratory activities for the Y-12 Plant GWPP. Sampling field support is obtained through the K-25 ASO Sampling and Environmental Support Department, and from the EMD Compliance Monitoring Section. The Y-12 Plant GWPP Sampling and Analysis Coordinator interacts with the managers of these respective organizations on a daily basis to set sampling schedules and coordinate access to sites. Coordination with Y-12 Plant Waste Management Organization is also required for containment and disposal of purged groundwater when required.

\subsection{DATA MANAGEMENT}

Management of the groundwater measurements data set is the responsibility of the Y-12 GWPP Database Manager. This position is currently filled by a database professional under subcontract to Energy Systems. The Database Manager reports to the GWPP Manager. Primary responsibilities of the Database Manager are to:

- Design, update, and maintain Statistical Analysis System (SAS) data sets for data collected and analyzed during implementation of the Y-12 Plant Groundwater Monitoring Program.

- Assist in the design, implementation, update, and maintenance of the Y-12 Plant Data Management Plan.

- $\quad$ Assist statistical analysis personnel with sampling and data transfer tracking activities relative to the schedules established in the Y-12 Plant Groundwater Monitoring Program. 
- Implement data verification to ensure that data quality objectives established by the Y-12 Plant GWPP are met.

- Establish and implement procedures for database security and backup.

- $\quad$ Respond to hard copy and electronic data transfer requests made to and approved by the GWPP Manager.

- Generate summary statistics for Y-12 Plant monitoring sites for the annual ORR Environmental Surveillance Report.

\subsection{DATA ANALYSIS, DATA VALIDATION, AND EVALUATION}

Statistical analysis, validation, and evaluation of groundwater data are currently conducted by a subcontractor to Energy Systems. The subcontractor coordinates statistical analysis activities with the GWPP Manager and personnel responsible for hydrogeological interpretation (see Section 4.11). Primary responsibilities in the area of statistical analysis are to:

- $\quad$ Perform statistical evaluations and reporting required by RCRA for the waste disposal sites included in the Groundwater Monitoring Program.

- Generate summary statistics and graphical presentations in response to requests made or approved by the GWPP manager.

- Assure the quality of the statistical analyses performed.

- Assure the quality of chemical analyses through data evaluation and validation in accordance with the GWPP Data Management Plan and interface with the ASO representative.

- Compilation of the annual GWQRs.

\subsection{RECORDKEEPING AND DOCUMENT CONTROL}

Recordkeeping and document control for the Y-12 Plant GWPP are the ultimate responsibility of the GWPP Manager. These responsibilities include:

- Generation and archiving of reports and documents to meet regulatory requirements.

- Acquisition of appropriate reference and guidance documents and materials.

- Maintenance of a records tracking system and records center. 
Element managers within the GWPP are responsible for documenting and reporting activities related to individual programs. Control and tracking of these records and documents are included in the individual project plans (Section 5.0), and coordination of the recordkeeping and documentation is the responsibility of the GWPP Manager.

\subsection{HYDROGEOLOGICAL INTERPRETATION}

Hydrogeological interpretation of groundwater data and statistical results are the responsibility of the GWPP Manager. Assisting the GWPP Manager with hydrogeological interpretation are various hydrogeological subcontractors, consultants from the ORNL and the University of Tennessee in Knoxville, and staff from the GWPO and ORR Hydrologic and Geologic Studies (ORRHAGS). Primary responsibilities of the GWPP Manager for hydrogeological interpretations are:

- Preparation of technical reports and correspondence.

- Serving as technical consultant to other programs.

- Identification of needs for hydrogeological subcontractor services.

- Serving as technical contact for subcontracts.

- Special groundwater and hydrogeologic studies.

\subsection{ENVIRONMENTAL RESTORATION PROGRAM}

All groundwater remedial and investigative activities relating to CERCLA regulatory compliance are within the scope of the Y-12 Plant ERP. The Y-12 Plant ERP interacts either directly with the GWPP Manager or through the Data Quality/ERP and D\&D Program Interface. Collaboration on groundwater or hydrogeologic issues may also occur through channels within the GWPO. The primary responsibilities of the Y-12 Plant ERP relative to groundwater issues include:

- $\quad$ Procure and administrate funding from appropriate sources.

- Define the groundwater characterization requirements and Data Quality Objectives for CERCLA RI efforts.

- Define the groundwater monitoring and data quality requirements for CERCLA RODs and RCRA post-closure permits. 
- Define the document management requirements of the Administrative Record.

- $\quad$ Perform surveillance and audits of ER-funded groundwater field activities.

- Define and prepare all documents required by CERCLA. Negotiate FFA milestones with the EPA and TDEC.

The GWPP is responsible for providing technical and data resources to the Y-12 Plant ERP as requested. In addition, the GWPP implements CERCLA-driven groundwater monitoring as a customer service organization at the request of the Y-12 Plant ERP.

\subsection{ENERGY SYSTEMS GROUNDWATER PROGRAM OFFICE}

The Energy Systems GWPO was established in May 1991 as a central technical and management resource for all groundwater programs at the five plants operated by Energy Systems for DOE. The overall goals of the GWPO are:

- To fully comply with all Federal and State statues and DOE orders pertaining to groundwater.

- To develop a groundwater program that is technically sound, consistent among the Energy Systems facilities, and responsive to the needs of DOE and the regulators.

- To establish a mechanism for technical support to the ORR facilities which addresses fundamental principles of groundwater flow and contaminant migration and the integration of this information at the installation level to the various monitoring programs.

Programmatically, each GWPP Manager reports through the GWPO. Technical support to the ORR facility GWPPs is provided through the Oak Ridge Hydrology Support Program (ORHSP). The ORHSP organization consists of three components: technical support, environmental surveillance, and ORRHAGS. Assistance is provided by ORHSP to the site GWPP for technical questions related to groundwater and for communicating technical guidance related to groundwater monitoring programs. 
In addition, the GWPO provides guidance and consistency relating to development of procedures and policies and document input and review. Guidance on regulatory issues is also provided by GWPO representatives. Specifics concerning the structure, functions, and responsibilities of the GWPO may be found in the "Martin Marietta Energy Systems Groundwater Program Management Plan" (Energy Systems 1993a). 


\subsection{PROJECT PLANS}

This section provides a summary of the various project plans that have been developed or are under development to guide the execution of all aspects of the Y-12 Plant GWPP. The actual plans are contained in the references cited within the text.

\subsection{HEALTH AND SAFETY PLANS}

A comprehensive Health and Safety Plan for environmental programs and emergency response at the Y-12 Plant has been completed (Energy Systems 1995). In addition, several specific activities of the GWPP have Health and Safety Plans under development or in effect. All drilling and well installation activities are conducted in accordance with an approved plan (SAIC, Inc. 1992) that ensures that all health and safety requirements of 29 CFR 1910.120 are satisfied. The field operations Health and Safety Plan summarizes general health and safety information and policies, identifies responsibilities for GWPP and subcontractor personnel, outlines personal protective clothing requirements, outlines first aid and medical screening procedures, summarizes potential health and safety hazards, and specifies procedures and safe work practices that are to be followed. A Health and Safety Plan specific to sampling activities is under development and will be an attachment to the comprehensive health and safety plan for environmental programs cited above.

\subsection{QUALITY ASSURANCE PLANS}

A comprehensive Quality Program Plan (QPP) for the Y-12 Plant GWPP is the current principal QA guidance source for the GWPP (SAIC, Inc. 1994). The QPP plan identifies key personnel responsible for implementation and provides for the planning and accomplishment of activities affecting quality assurance. Specifically, the plan addresses procurement procedures, document control, sample identification and control, qualification requirements for analytical and sampling techniques, equipment calibration requirements, corrective actions, and quality assurance records and audits. Separate Quality Assurance Plans (QAPs) for the HSEA Compliance Monitoring Section and RFIs are in effect (Energy Systems, Inc. 1990) that address similar issues. Although the GWPP Manager is ultimately responsible for the implementation of QA requirements and for assuring and verifying the quality of the GWPP, each element or project manager is responsible for day-to-day 
$\mathrm{QA} / \mathrm{QC}$ requirements. In addition to the GWPP Manager, implementation of the QA requirements is supported by the QA Coordinator.

To supplement existing QAPs, environmental surveillance procedures have been developed (Lockheed Martin Energy Systems, Inc. 1988). This manual represents a consolidated source of requirements, instructions, and information concerning environmental data gathering, sampling and analysis. Included is a description of each activity, its scope and application, references, a summary of methods, pertinent comments, a list of required equipment and supplies, safety requirements and considerations, procedures, contamination control, and $\mathrm{QA} / \mathrm{QC}$ requirements.

\subsection{GROUNDWATER MONITORING WELL INSTALLATION PLAN}

A Groundwater Monitoring Well Installation Plan is developed for each calendar year. The plan includes the number and locations of monitoring wells to be installed, completion zones and construction specifications for each well or type of well, a schedule for installation, and documentation requirements for well installations and development. Well specifications and the procedures and equipment needed to construct, install, and develop groundwater monitoring wells are contained in Geraghty \& Miller, Inc. (1985d) and the RCRA Technical Enforcement Guidance Document (EPA 1986b). Environmental surveillance procedures relating to well installation are contained in Energy Systems (1988). To supplement the Well Installation Plan, procedures consistent with Energy Systems and DOE policies for the disposal of drill cuttings and fluids and well development water (currently in draft form) will be finalized.

The GWPP Technical Manager is responsible for generating and implementing the Well Installation Plan and ensuring that it meets regulatory and programmatic needs. Additionally, the GWPP Manager is responsible for obtaining adequate funding for the implementation of the Well Installation Plan. Upon request from the GWPP Manager, the GWPP Technical Manager initiates engineering service orders and work releases to obtain subcontractor services and engineering support for well installations and coordinates geotechnical oversight. Engineering service orders are approved by the Energy Systems Procurement Division and the HSEA Organization Finance Officer. The geotechnical subcontractor (a registered geologist or registered professional geologist in the 
State of Tennessee) ensures that the drilling subcontractor complies with technical specifications and procedures for well installations and documents all well construction and development information. The geotechnical subcontractor also provides health and safety monitoring at the site in accordance with the field operations health and safety plan (SAIC Inc. 1992). An annual report documenting all well installation activities is issued.

\subsection{SAMPLING AND ANALYSIS PLAN}

The annual Groundwater Sampling and Analysis Plan is maintained by the GWPP Sampling and Analysis Coordinator. The plan is a breakdown of the monitoring program by site or subsite, and identifies wells to be sampled, sampling schedule and frequency, the order in which wells are to be sampled, chemical parameters of interest, and a reporting schedule. The plan is updated throughout the current year as requirements dictate via addenda to the plan.

The responsibility for developing the annual Groundwater Sampling and Analysis Plan rests with the GWPP Manager, who integrates the monitoring requirements for the five basic programs described in Section 2.0 into the plan:

- Detection monitoring;

- Assessment monitoring;

- DOE Order 5400.1 Surveillance monitoring;

- DOE Order 5400.1 Perimeter and Exit Pathway monitoring;

- Corrective-action monitoring; and

- Best Management Practice Monitoring

Monitoring results for all programs are contained in the GWQRs, which are prepared by data analysis and evaluation subcontractors to the GWPP. The GWQRs contain rationale and justification for additional well installations and sampling recommendations for all sites from which the annual Groundwater Sampling and Analysis Plan is extracted. 


\subsection{LABORATORY QA PLAN}

A laboratory QA plan for groundwater monitoring activities at the Y-12 Plant was issued in May 1991 (Energy Systems 1991). This QA plan describes techniques and systems necessary to obtaining reliable characterization data from groundwater wells and to ensure uniform results. The plan provides a standard for all activities involved in collecting and analyzing samples, and in reporting data. Specifically, it contains procedures that are to be followed for sample collection, sample preservation and handling, chain of custody, sample analysis, QA/QC, and data quality evaluation.

The Y-12 Plant ASO representative is responsible for the actual implementation of the Laboratory QA Plan. The representative coordinates and schedules sampling (with the Sampling and Analysis Coordinator) and analysis of all groundwater wells specified in the Groundwater Sampling and Analysis Plan (Section 5.4). Analytical services provided by external laboratories, when required, are coordinated by the APO with assistance from the ASO representative. The ASO representative is responsible for the quality of the data prior to its electronic release to the Database Manager who archives all data, both electronically and on hard copy. The ASO representative also tracks analytical costs and notifies the GWPP Manager of any potential cost increases or potential overruns.

The GWPP Sampling and Analysis Coordinator is responsible for the actual sampling of groundwater monitoring wells in accordance with the Laboratory QA Plan and the Groundwater Monitoring Plan. In addition to those responsibilities outlined in Section 4.2.3, the Sampling and Analysis Coordinator also implements corrective actions resulting from field QA deficiencies. The Sampling and Analysis Coordinator also maintains well sampling histories and provides timely notification of any unusual circumstances (e.g., dry well conditions, extraordinarily high or low water levels, vapors or odors noted, discolored water, well damage, missing locks or caps, evidence of tampering, etc.) to the GWPP Manager and ASO representative.

\subsection{DATA MANAGEMENT PLAN}

A Data Management Plan has been developed for the Y-12 Plant GWPP (H\&R Technical Associates, Inc. 1993). Implementation of the Data Management Plan is the responsibility of the 
Database Manager with support from statistical analysis support personnel, the ASO representative, and GWPP Manager. Data are tracked between the ASO representative and the statistical analysis support personnel utilizing software in conjunction with tracking reports. Analytical data are transferred electronically upon completion of analysis of samples from a site or subsite. Weekly summary reports and field sampling sheets are sent from the ASO representative to the GWPP Sampling and Analysis Coordinator. Hard copies of data are sent to the Database Manager and the statistical subcontractor as well groupings are completed. The Data Management Plan is modified as required and changes are documented by the Database Manager.

\subsection{CERCLA PLANS}

All CERCLA RI or post-closure activities (RCRA post-closure permits or CERCLA RODs) pertaining to groundwater at the Y-12 Plant are overseen by the Y-12 Plant ERP. The ERP coordinates groundwater-related activities with the Y-12 Plant GWPP through direct interaction with the GWPP manager, GWPP Technical Manager, or Sampling and Analysis Coordinator. Coordination efforts may also be conducted through EMD management and the ERP Interface.

Site-specific groundwater monitoring requirements are presented within the context of individual RI work plans, post-closure permits, or CERCLA RODs. The ERP is responsible for communicating CERCLA groundwater monitoring requirements of closure operations to the GWPP Manager. The GWPP Manager is responsible for integration of these requirements into ongoing $Y$ 12 Plant GWPP activities.

\subsection{WELL PLUGGING AND ABANDONMENT PLAN}

Decommissioning of damaged, unusable, or no-longer needed groundwater monitoring and investigation wells is outlined in a Well Plugging and Abandonment Plan (HSW Environmental Consultants, Inc. 1991a). Wells of similar construction materials and design are grouped together, and a single procedure was developed for each group of wells. The objective of each procedure is to prevent fluid migration into or between formations containing groundwater, to remove any well materials that may have been in contact with contaminated material or groundwater, and to minimize the amount of waste materials generated during the plugging and abandonment procedure. 
The GWPP Manager is responsible for generating an inventory of wells considered for plugging and abandonment, reviewing the plan annually, and issuing addenda as needed. The GWPP Manager designates wells to be plugged and abandoned through coordination with managers of other plant programs, review of well inspection and maintenance reports, and review of the annual GWQRs. Well inspection and maintenance reports identify wells that are damaged or unusable. Managers of other plant programs identify wells that must be removed because of construction or site closure activities. Wells no longer needed as part of a monitoring well network are identified during evaluation of data as part of the GWQRs. The GWPP Manager, with assistance from the GWPP Technical Manager, is also responsible for developing a schedule of plugging and abandonment activities, obtaining subcontractor services for the plugging and abandonment, obtaining engineering support for field operations oversight, and ensuring that the subcontractor complies with the plugging and abandonment procedures. An annual report documenting plugging and abandonment activities is issued.

\subsection{WELL INSPECTION AND MAINTENANCE PLAN}

A plan has been developed for the inspection and maintenance of monitoring wells to extend the life of wells and to ensure the wells yield representative water levels and water-quality samples (HSW Environmental Consultants, Inc. 1991b). Development and implementation of the Well Inspection and Maintenance Plan is the responsibility of the GWPP Field Projects Manager. The plan includes a list of wells requiring inspection, a checklist of items to be inspected (such as condition of concrete pads, hasps, caps, locks, and protective posts; the measured depth of the monitored interval compared to the constructed depth; and well access considerations), standardized forms for inspection and requests for maintenance, and a schedule for well inspections. The plan also includes procedures for inspection and reporting. As wells are inspected and problems requiring attention are identified, a schedule to repair or rehabilitate wells is developed and updated through the year. Additionally, problems reported by sampling teams to the GWPP Manager are added to the repair/rehabilitation schedule. 


\subsection{REFERENCES}

Bechtel National, Inc., 1984a. "Interim Report on Bear Creek Valley Oil Landfarm Geology and Hydrogeology." Y/SUB/84-47974C/1.

Bechtel National, Inc., 1984b. "Geologic and Hydrologic Data for Bear Creek Valley Burial Grounds A and B." Y/SUB/84-47974C/2.

Bechtel National, Inc., 1984c. "The Geology and Hydrogeology of Bear Creek Valley Waste Disposal Areas A and B." Y/SUB/84-47974C/3.

Bechtel National, Inc., 1984d. "Interim Report on the Geology and Hydrogeology of the Southern and Western Perimeter to the Burial Grounds and the Interior Portions of Bear Creek Valley Waste Disposal Areas Environmental Field Studies." Y/SUB/84-47974C/4.

Bechtel National, Inc., 1985. "Geologic Data on Twenty Monitoring Wells Installed in Bear Creek Valley in September and October 1984." Y/SUB/84-477974C12.

Dreier, R.B., K.D. Solomon, and C.M. Beaudoin, 1987. "Fracture Characterization in the Unsaturated Zone of a Shallow Land Burial Facility." In: Flow and Transport through Fractured Rock, American Geophysical Union Monograph 42."

Dreier, R.B., T.O. Early, and H.L. King, 1993. "Results and Interpretation of Groundwater Data Obtained from Multiport-Instrumented Coreholes (GW-131 through GW-135), Fiscal Years 1990 and 1991." Y/TS-803.

Geraghty \& Miller, Inc., 1985a. "Evaluation of Monitoring Well Network in the Bear Creek Valley Waste Disposal Area." Y/SUB/85-00206C/1.

Geraghty \& Miller, Inc., 1985b. "Preliminary Findings of the 1984-85 Investigations of Contamination at the S-3 Ponds." Y/SUB/8400206/3.

Geraghty \& Miller, Inc., 1985c. "Remedial Alternatives for Bear Creek Valley Waste Disposal Area." Y/SUB/85-00206C/3.

Geraghty \& Miller, Inc., 1985d. "Guidelines for Installation of Monitor Wells at the Y-12 Plant." Y/SUB/85-00206C/6.

Geraghty \& Miller, Inc., 1986. "Phase IV Monitor-Well Drilling Program in the Bear Creek Valley Waste Disposal Area." Y/SUB/85-00206C/8. 
Geraghty \& Miller, Inc., 1987a. "Preliminary Evaluation of Hydrogeologic and Water Quality Data from Phase IV Wells Located in Bear Creek Valley Waste Disposal Area for the Period Summer 1985 - September 1986." Y/SUB/87-00206C/9.

Geraghty \& Miller, Inc., 1987b. "Proposed RCRA Groundwater Quality Assessment Plan for the S-3 Ponds Hazardous Waste Disposal Unit at the Y-12 Plant." Y/SUB/87-00206C/4.

Geraghty \& Miller, Inc., 1987c. "Proposed RCRA Groundwater Quality Assessment Plan for the Oil Landfarm Hazardous Waste Disposal Unit at the Y-12 Plant." Y/SUB/87-00206/6.

Geraghty \& Miller, Inc., 1987d. "Proposed RCRA Groundwater Quality Assessment Plan for the Burial Grounds Hazardous Waste Disposal Unit at the Y-12 Plant." Y/SUB/87-00206C/3.

Geraghty \& Miller, Inc., 1987e. "Proposed RCRA Groundwater Quality Assessment Plan for New Hope Pond at the Y-12 Plant." Y/SUB/87-00206C/17.

Geraghty \& Miller, Inc., 1988a. "Proposed RCRA Groundwater Quality Assessment Plan for the Chestnut Ridge Security Pits Hazardous Waste Disposal Unit." Y/SUB/87-00206C/19.

Geraghty \& Miller, Inc, 1988b (Revised). "Post Closure Permit Application for the S-3 Ponds Waste Management Area at the Y-12 Plant." Prepared for Martin Marietta Energy Systems, Inc. Y/SUB/87-00206C/11.

Geraghty \& Miller, Inc, 1988c (Revised). "Post Closure Permit Application for the Oil Landfarm Waste-Management Area at the Y-12 Plant." Prepared for Martin Marietta Energy Systems, Inc. Y/SUB/87-00206C/12.

Geraghty \& Miller, Inc, 1988d (Revised). "Post Closure Permit Application for the Burial Grounds Waste-Management Area at the Y-12 Plant." Prepared for Martin Marietta Energy Systems, Inc. Y/SUB/87-00206C/13.

Geraghty \& Miller, Inc, 1989. "Post Closure Permit Application for Chestnut Ridge Security Pits Hazardous-Waste Disposal Unit at the Y-12 Plant." Prepared for Martin Marietta Energy Systems, Inc. Y/SUB/89-00206C/10.

Geraghty \& Miller, Inc., 1990. "Comprehensive Groundwater Monitoring Plan for the Department of Energy Y-12 Plant, Oak Ridge, Tennessee." Y/SUB/90-00206C/5.

H\&R Technical Associates, Inc., 1993. "Y-12 Plant Groundwater Protection Program-Groundwater Monitoring Program Data Management Plan." Y/SUB/93-TK532C/1.

HSW Environmental Consultants, Inc., 1991a. "Monitor Well Plugging and Abandonment Plan for the Department of Energy Y-12 Plant, Oak Ridge, Tennessee." Y/SUB/91-YP507C/6. 
HSW Environmental Consultants, Inc., 1991b. "Monitor Well Maintenance and Inspection Plan for the Department of Energy Y-12 Plant, Oak Ridge, Tennessee." Y/SUB/91-YP507C/5.

Haase, C. S., G. A. Gillis, and H. L. King, 1987a. "Fiscal Year 1985 Groundwater Investigation Drilling Program at the Y-12 Plant, Oak Ridge, Tennessee." ORNL/TM-9999.

Haase, C. S., H. L. King, and G. A. Gillis, 1987b. "Preliminary Hydrological and Hydrochemical Assessment of the Beta-4 Security Pit, the Kerr Hollow Quarry, the Ravine Disposal, the Rogers Quarry, and the United Nuclear Sites at the Y-12 Plant, Oak Ridge, Tennessee." Y/TS-272.

Haase, C. S., H. L. King, and G. A. Gillis, 1987c. "Preliminary Hydrological and Hydrochemical Assessment of the Chestnut Ridge Security Pits, the Chestnut Ridge Sludge Disposal Basin, and the New Hope Pond Sites at the Y-12 Plant, Oak Ridge, Tennessee." Y/TS-272.

Ketelle, R. H., and D. D. Huff, 1984. " Site Characterization of the West Chestnut Ridge Site." ORNL/TM-9229.

Kimbrough, C. W., L. W. Long, L. W. McMahon, 1987. "Environmental Surveillance Procedures Quality Control Program, Martin Marietta Energy Systems, Inc." ESH/SUB/87-21706/1.

King, H. L. and C. S. Haase, 1987. "Subsurface-Controlled Geological Maps for the Oak Ridge Y-12 Plant and Portions of Bear Creek Valley." ORNL/TM-10112.

King, H. L. and C. S. Haase, 1989. "Results and Preliminary Interpretation of Hydrogeologic Packer Testing in Core Holes CH-157, GW-131, and GW-132 through GW-135 at the Oak Ridge Y-12 Plant." Y/TS-495.

King, H. L. And C. S. Haase, 1990. "Oak Ridge Y-12 Plant Groundwater Protection Program Management Plan", Y/TS-633.

King, H. L., D. L. Schaefer, and C. S. Haase, 1989. "Updated Subsurface Data Base for Bear Creek Valley, Chestnut Ridge, and Parts of Bethel Valley on the U.S. Department of Energy Oak Ridge Reservation." Y/SUB/89-E437V/1.

Lagan, C., Tennessee Department of Environment and Conservation, Letter to D.J. Bostock, Martin Marietta Energy Systems, Inc., January 9, 1992. "Approval for False Positive Demonstration for Chestnut Ridge Sediment Disposal Basin and Kerr Hollow Quarry."

Law Engineering, 1983. "Results of Groundwater Monitoring Studies." Y/SUB/83-47936/1.

Lee, R. R. and R. H. Ketelle, 1989. "Geology of the West Bear Creek Site." ORNL/TM-0887.

Lockheed Martin Energy Systems, Inc., 1995. "Y-12 Plant Hazardous Waste Operations and Emergency Response Program." Y/TS-638/R2. 
Martin Marietta Energy Systems, Inc., 1988. "Environmental Surveillance Quality Control Program." ES/ESH/INT-14.

Martin Marietta Energy Systems, Inc., 1990. "Oak Ridge Y-12 Plant Environmental Monitoring Section Quality Assurance Plan." Martin Marietta Energy Systems, Inc. Oak Ridge Y-12 Plant. QAP-Y-89-HSEA-7016, June 30, 1990.

Martin Marietta Energy Systems, Inc., 1991. "Laboratory Quality Assurance Project Plan for the Sampling of Groundwater Wells at the Y-12 site on the Oak Ridge Reservation." QAP:0490-0014, REV. 0, May 1991.

Martin Marietta Energy Systems, Inc., 1993. "Martin Marietta Energy Systems Groundwater Program Management Plan." ORNL/GWPO-001, Draft, February 2, 1993.

McMahon and Mercier, 1992. "Annual Report of 1991 Groundwater Monitoring Data for the Kerr Hollow Quarry and Chestnut Ridge Sediment Disposal Basin at the Y-12 Plant: Reporting and Statistical Evaluation of the Subsequent Year (Sixth) Data." Y/TS-833/P2.

Moore, G.K., 1989. "Groundwater Parameters and Flow System Near Oak Ridge National Laboratory. Environmental Sciences Division, Oak Ridge National Laboratory. ORNL/TM11368 .

Murphy, 1989. "Supplement to Solid Waste Management Unit Information for Y-12 Plant RCRA 3004(u) Facility Assessment." Y/TS-273 Supplement 4.

Pritz, P.M., 1983. "Master Monitoring Plan for Groundwaters and Surface Waters. Oak Ridge Y-12 Plant." Unnumbered Martin Marietta Energy Systems, Inc. Document.

Rothschild, E. R., R. R. Turner, S. H. Stow, M. A. Bogle, L. K. Hyder, O. M. Sealand, and H. J. Wyrick, 1984. "Investigation of Subsurface Mercury at the Oak Ridge Y-12 Plant." ORNL/TM-9092.

Science Applications International Corporation., Inc. (SAIC), 1992. "Health and Safety Plan for Well Installation and Plugging and Abandonment Activities, Y-12 Plant, Oak Ridge, Tennessee." Y/SUB/92-99928C(Y11)/1.

Science Applications International Corporation, Inc. (SAIC), 1994. "Groundwater Protection Program Quality Program Plan." Y/SUB/94-99069C/Y13/1.

Science Applications International Corporation., Inc. (SAIC), 1996. "Remedial Investigation Report for Bear Creek Valley." (Preliminary Draft).

Shevenell, L. A., R. B. Dreier, and W. K. Jago, 1992. "Summary of Fiscal Year 1991 and 1992 Construction, Hydrologic, and Geologic Data Obtained from the Maynardville Limestone Exit Pathway Monitoring Program." Y/TS-814. 
Sledz, J.S., and D.D. Huff, 1981. "Computer Model for Determining Fracture Porosity and Permeability in the Conasauga Group, Oak Ridge National Laboratory, Tennessee." Environmental Sciences Division Publication No 1677, ORNL/TM-7695.

Solomon, D. K., G. K. Moore, L. E. Toran, B. B. Dreier, and W. M. McMaster, 1992. "Status Report - A Hydrologic Framework for the Oak Ridge Reservation." ORNL/TM-12026.

Tennessee Department of Environment and Conservation (TDEC), 1992a. "Environmental Assessment Guidelines." TDEC Division of Underground Storage Tanks, January 1992.

Tennessee Department of Environment and Conservation (TDEC), 1992b. "Environmental Assessment Report Guidelines." TDEC Division of Underground Storage Tanks, January 1992.

Tennessee Department of Environment and Conservation (TDEC), 1992c. "Corrective Action Plan Guidelines." TDEC Division of Underground Storage Tanks, January 1992.

U.S. Department of Energy (DOE), 1991. Letter from J. LaGrone, Manager of DOE Oak Ridge Operations, to G. C. Tidwell, EPA Region IV Administrator, and J. W. Luna, Commissioner of the TDEC, October 30, 1991.

U.S. Department of Energy (DOE), 1994. "Oak Ridge Reservation Site Management Plan for the Environmental Restoration Program. U. S. Department of Energy Oak Ridge Field Office. (DOE/OR-1001/R3).

U.S. Department of Energy (DOE), 1995. "Environmental Monitoring Plan for the Oak Ridge Reservation. U.S. Department of Energy Oak Ridge Field Office.” (DOE/OR-1066/R1).

U.S. Environmental Protection Agency (EPA), 1985. "RCRA Groundwater Monitoring Compliance Order Guidance." U.S. Environmental Protection Agency, Office of Waste Programs Enforcement, Washington, DC.

U.S. Environmental Protection Agency (EPA), 1986a. "RCRA Facility Assessment Guidance." U.S. Environmental Protection Agency, Waste Management Division, Office of Solid Waste, Washington, DC.

U.S. Environmental Protection Agency (EPA), 1986b. "RCRA Groundwater Monitoring Technical Enforcement Guidance Document."

U.S. Environmental Protection Agency (EPA), 1988. Letter from J.H. Scarbrough, Chief of the Region IV RCRA Branch, and T. Tiesler, Director of the Division of Solid Waste Management, Tennessee Department of Health and Environment, to R.J. Spence, Y-12 Plant Manager, U.S. Department of Energy - Oak Ridge Operations, November 18, 1988. 
U.S. Environmental Protection Agency (EPA), 1989. "Statistical Analysis of Groundwater Monitoring Data at RCRA Facilities-Interim Final Guidance." PB89-151047.

Welch, S.H. 1987. Solid Waste Management Unit Information for Y-12 Plant RCRA 3004(u) Facility Assessment Container Accumulation Areas. Martin Marietta Energy Systems, Inc., Y-12 Plant Environmental Management Department, Health, Safety, Environment and Accountability Division. Y/TS-273, Supp.2.

Welch, S.H., C.S. Haase, C.W. Kimbrough, and T.M. Mercier. 1987. "Solid Waste Management Unit Information for Y-12 Plant RCRA 3004(u) Facility Assessment, Volumes I, II, and III." Martin Marietta Energy Systems, Inc. Y/TS-273.

Wiggins, K.D., and S.H. Welch. 1988a. "Supplement to Solid Waste Management Unit Information for Y-12 Plant RCRA 3004(u) Facility Assessment." Martin Marietta Energy Systems, Inc., Y-12 Plant Environmental Management Department, Health, Safety, Environment and Accountability Division. Y/TS-273, Supp.1.

Wiggins, K.D., and S.H. Welch. 1988b. "Supplement to Solid Waste Management Unit Information for Y-12 Plant RCRA 3004(u) Facility Assessment Container Accumulation Areas." Martin Marietta Energy Systems, Inc., Y-12 Plant Environmental Management Department, Health, Safety, Environment and Accountability Division. Y/TS-273, Supp.3. 
APPENDIX A

ENERGY SYSTEMS POLICY PROCEDURES

ESS-EP-101 "ENVIRONMENTAL PROTECTION PROGRAM" AND

ESS-EP-134 "GROUNDWATER PROTECTION PROGRAM" 
-

-

- 


\section{PURPOSE}

This standard establishes and maintains environmental protection program requirements for Martin Marietta Energy Systems, Inc., in a manner that is consistent with Corporate and Department of Energy (DOE) policy and that meets the requirements of federal, state, and local regulations.

This standard supersedes Energy Systems Policy Procedure ESH-14, "Environmental Protection," dated March 12, 1990.

\section{REQUIREMENT REFERENCES}

A. DOE Order 5000.3A, 05/3090, and OR Order 5000.3B, Occurrence Reporting and Processing of Operations Information, 08/30/90

B. DOE Order, 06/27/90, and OR Order 5400.1, General Environmental Protection Program, 08/30/90

C. DOE Order 5400.2A, 01/31/89, and OR Order 5400.2, Environmental Compliance Issue Coordination, $1107 / 88$

D. DOE Order 5400.3, Hazardous and Radioactive Mired Waste Program, 02/22/89

E DOE Order 5400.4, Comprehensive, Environmental Response, Compensation, and Liability Act, Requirements, 10/06/89

F. DOE OTder 5400.5, Radiation Protection of the Public and the Environment, 06/05/90

G. DOE Order 5440.1D, National Environmental Policy Act Compliance Program, 02/22/91

H. OR Order 5440.1B Implementation of the National Environmental Protection Act, 08/23/82

I. DOE Order 5480.1B, Environment, Safety, and Health Program for Department of Energy Operations, $03 / 2790$

J. OR Order 5480.1A, Environment, Safery, and Health Program for ORO, 06/22/82

K DOE Order, 05/15/84, and OR Order 5480.4, Environmental Protection, Safety, and Health Protection Standards, 02/26/85

L. DOE Order 5482.1B, 09/23/86, and OR Order 5482.1A, Environmental, Safety, and Health Protection Appraisal Program, 04/19/82

M. DOE Order, 10/17/90, and OR Order 5484.1, Environmental Protection, Safety, and Health Protection Information Reporting Requirements, 05/05/82

N. DOE Order 5820.2A, Radioactive Waste Management, 09/26/88

O. Martin Marietta Corporate Policy GP-04, "Environmental Protection," 08/09/90

P. Martin Marietta Corporate Operating Instruction ENV-01, "Environmental Management," 08/14/90

Q. Energy Systems Policy ES-EH-100, "Environmental, Safety, and Health Policy Statement," latest issue 


\section{REQUIREMENT REFERENCES (cont.)}

R. Energy Systems Standard ESS.ENV.1, "Environmental, Safety, Health, and Waste Management Quality Assurance Program," latest issue

S. Energy Systems Standard ESS-EH-101, Environmental, Safety, and Health Activities Required Records," latest issue

T. Energy Systems Standard ESS-EH-102, "Energy Systems Environmental Safety and Health Activities," latest issue

U. Energy Systems Standard ESS-EP-301, "Analytical Methods for Environmental Analyses," latest issue

V. Energy Systems Standard ESS-OP-301, "Occurrence Reporting System," latest issue

\section{SCOPE/LIMITATIONS}

This standard is applicable to all Energy Systems installations and organizations.

\section{DEFINITIONS}

A. Efiluent - any aqueous or airborne stream that is released to the environment (i.e., air, water, and ground), not including solid wastes or waste streams that are contained or stored.

B. Environmental Assessment - a documented assessment of a facility, program, or project to monitor the progress of necessary corrective actions, to assure compliance with environmental laws and regulations, and to evaluate field organization practices and procedures.

C. Eavironmental Monitoring - the collection and analysis of samples or direct measurements of environmental media as defined in DOE Order 5400.1. Environmental monitoring consists of two major activities: efluent monitoring and environmental surveillance.

D. Environmental Occurrence - any sudden release or sustained deviation from a regulated or planned performance at a DOE operation that has environmental protection and compliance significance.

E. Functional Appraisal - a documented review of an environmental specialty discipline performed in accordance with written guidance and criteria to verify, by examination and evaluation of objective evidence at the facility and/or operation, that applicable elements of the program have been developed, documented, and effectively implemented in accordance with specific Environmental, Safety, and Health (ES\&H) requirements and needs.

F. Internal Apprisal - an examination and evaluation by the operating level (Energy Systems) of those portions of its internal ES\&H program, program plan implementation, and operations retained under its direct control.

G. Management Appraisal - a documented determination of managerial effectiveness in establishing and implementing environmental program pians that conform to DOE policy requirements. It is based on an analysis of functional appraisals, internal appraisals, and other information and on the application of appropriate criteria. The appraisal is a review and evaluation of management performance covering all environmental disciplines and management responsibilities to assure proper program balance. This appraisal is currently conducted at each installation annually. 


\section{DEFINITIONS (cont.)}

H. Mandatory Standards - those standards of DOE Orders 5400.1 and OR 5400.1 adopted by DOE that define the minimum requirements that must be complied with to the extent they apply to the activities being conducted.

1. Resource Management Organization - an Energy Systems Oak Ridge Reservation-wide committee chaired by a person from the Environmental Compliance organization. This committee was established to develop a plan and manage the resources of the Oak Ridge Reservation, particularly those areas outside the plant perimeter fences at each installation. Resources include wetlands, Iloodplains, rare/endangered plants and animals, archaeological, cultural, and historical sites, and research areas.

J. Significant Emviroamental Compliance lssue - an issue that is or bas the potential of being precedent setting or controversial, and/or involves DOE notification, concurrence, or approval. (DOE Order 5400.2)

\section{REQUIREMENTS}

A. This standard will become effective $\mathbf{4 5}$ days from the date of the document or when the document is received by a controlled manual holder, whichever comes first.

B. Establish and implement environmental protection program standards and procedures responsive to Energy Systems ES\&H policy to ensure compliance with federal, state, and local environmental protection laws and regulations, federal executive orders, internal DOE orders, and Energy Systems policy. (DOE Order 5400.1)

C. Ensure that any proposed actions by Energy Systems that may potentially have a significant effect upon the quality of the environment be reviewed as required by the National Environmental Policy Act of 1969 (NEPA) for environmental impacts and that this review be documented and maintained as a QA Record. (DOE Order 5440.1D)

D. Identify significant environmental compliance issues and implement plans to ensure timely development and consistent application of DOE and Energy Systems environmental policies and guidance to meet the intent of DOE Order 5400.2A.

E Ensure compliance with the mandatory standards of DOE Order 5400.1 and OR 5400.1 .

F. Ensure that environmental policies and standards are appropriately interpreted and implemented within Energy Systems organizations through an internal Environmental Appraisal Program. (DOE Order 5482.1B)

G. Develop and maintain systems for collection, retention, evaluation, and dissemination of information that characterizes Energy Systems environmental programs, then monitor and report to demonstrate compliance with environmental protection laws and regulations. (DOE Order 5484.1)

H. Establish and maintain a system and procedures to identify, evaluate, and report continuous releases of hazardous substances in accordance with Energy Systems directives and 40 CFR 302.8, Continuous Releases.

I. Maintain configuration control of the Environmental Monitoring and Surveillance Program in accordance with Energy Systems directives. 


\section{REQUIREMENTS (cont.)}

J. Prepare documentation and obtain the required environmental permits and licenses to allow scheduled start-up or continuous operation.

K. Conduct effluent monitoring and environmental surveillance programs that determine whether the public and the environment are adequately protected during Energy Systems operations and whether operations are in compliance with DOE and other applicable federal, state, and local standards and requirements. Where applicable, monitoring and surveillance programs must be capable of detecting and quantifying unplanned releases and must meet high standards of quality and credibility. Monitoring locations, type and frequency sampling, monitoring data, recordkeeping, and data reporting must comply with guidelines in DOE Order 5400.1 and DOE Order 5400.5 and must fulnill the following objectives:

1. Effluent Monitoring. Effluent monitoring is conducted to provide adequate measurement of liquid and airborne effluents as a basis for

2. obtaining data on the quantities and concentrations of air pollutants and water pollutants released to the environment for the purpose of evaluating the adequacy and effectiveness of containment, effluent treatment methods, and the potential for waste minimization and for overall effluent control; and

b. determining compliance with applicable environmental standards, licenses, permits, and monitoring requirements.

2. Environmental Surveillance. Environmental surveillance is conducted to provide adequate measurements of pollutants in various ambient environmental media as a basis for

a. obtaining baseline data on the quantities and/or concentrations of potential pollutants stored or moving in the environment for the evaluation and control of environmental impact;

b. determining compliance with applicable effluent control limits or release standards, including self-imposed standards designed to assure compliance with in-plant standards or guides;

c. detecting environmental trends and deviations related to plant operations that could result in environmental effects or changes as required by DOE Order 5400.1 and DOE Order 5400.5;

d. measuring progress in implementing improved environmental management practices and in evaluating remedial actions taken to correct deficiencies in past practices; and

e. reporting compliance with appropriate standards to inform the general public and to contribute to general environmental knowledge.

3. Eflluents. Each liquid and airborne effluent stream is examined with a view toward maintaining effluents at or below limits or guidelines and, as practicable, to reduce them below the guidelines.

4. Data Reporting. Prompt review, validation, and reporting of data is required.

2. Reporting frequencies shall comply with permit requirements.

b. Environmental occurrences shall be promptly reported to management through the Occurrence Reporting System. 


\section{REQUIREMENTS (cont.)}

c. Data and description material for the Annual Environmental Reports shall be provided on schedule to allow the Repon Coordinator to publish the report before or by the deadline date.

\section{RESPONSIBILITIES}

\section{A. Energy Systems Environmental Compliance Organization}

1. recommends and formulates all Level 1 environmental protection policies, procedures, and standards;

2 develops and coordinates compliance and permitting strategies and is the principal interface for Energy Systems with DOE in the resolution of technical or compliance issues with the environmental regulatory agencies;

3. conducts environmental protection audits or functional appraisals in conjunction with the Energy Systems Technical Audit program to ensure that the installations follow Energy Systems policies and guidelines and use consistent approaches (in procedures, regulations interpretation, analytical techniques, reporting, permitting, and equipment) to meet environmental protection objectives:

a. provides independent overview within Energy Systems, in conjunction with the Energy Systems Technical Audit program, to assess compliance with the mandatory standards, and to review, evaluate, and document management performance of environmental programs (DOE Order 5482.1B); and

b. establishes and maintains an Energy Systems Management Appraisal system in conjunction with the Director of Quality Assurance to review, evaluate, and document management performance of environmental programs, and maintains a tracking system to ensure follow-up of recommendations (DOE Order 5482.1B);

4. leads the Environmental Monitoring Task Team, which addresses specific environmental compliance issues [e.g., Clean Air Act, Clean Water Act, National Environmental Policy Act (NEPA), Resource Conservation and Recovery Act, and Toxic Substances Control Act] and promotes information exchanges among installation representatives;

5. ensures that the Energy Systems quality assurance requirements are met for the Environmental Protection Program at each installation (DOE Order 5700.6C);

6. promptly notifies the potentially affected installations of significant environmental compliance issues that may impact operations (DOE Order 5400.2);

7. provides NEPA technical assistance and policy guidance to each installation and major program in their preparation of appropriate NEPA documentation (DOE Order 5440.1D);

8. ensures timely review of proposed actions submitted by the installations for considerations regarding state and federal natural and cultural resource protection statutes:

a. ensures that proposed actions outside the installation fences on the Oak Ridge Reservation are reviewed and/or evaluated by the Resource Management Organization before submittal to DOE for review and comment; and 


\section{RESPONSIBILITIES (cont.)}

b. ensures that subsequent NEPA documentation is prepared by each installation, that it objectively addresses project alternatives, and that it inciudes a discussion of the impacts of the chosen action;

9. provides technical assistance to each installation to facilitate resolution of significant environmental compliance issues (DOE Order 5400.2);

10. has the responsibility and authority to close down an operation if mandatory standards and requirements are not met;

11. provides Energy Systems management and DOE with the information needed to understand and assess the resources on the Oak Ridge Reservation and to plan for optimal use and implement the management of these resources through the Resource Management Organization;

12. reviews, coordinates with, and submits to the DOE Director, Environmental Protection Division, requests for exemptions from the mandatory standards as delineated by the exemption procedures in DOE Order 5480.4;

13. identifies Energy Systems Environmental Compliance organization funding requirements, provides justification, and communicates these needs to each installation; and

14. communicates, before issuance, any new regulations to installations and major environmental protection programs that will have significant impact.

B. Each Installation and Program Managers

1. ensure that the Energy Systems Environmental Program is implemented through line organizations in a manner consistent with the mandatory standards of DOE Order 5400.1 and Energy Systems requirements, and have the responsibility and authority to close down an operation if mandatory standards and requirements are not met;

2. establish the necessary staff, service, and advisory groups to implement and maintain an effective Environmental Protection program, and designate staff members to serve on Energy Systems Environmental Committees or Task Teams;

3. establish annual environmental goals, plans, and budgets that identify the resources required to meet environmental objectives;

4. identify sources and characterize waste streams (air, liquid, and solids) to determine any significant hazardous constituents, concentrations, and quantities for managerial interests and inform DOE through the occurrence reporting system and regulatory agencies as necessary;

5. effect prompt actions to correct any violation of applicable regulations/standards and/or significant adverse trends in environmental quality resulting from plant operations;

6. develop emergency response procedures in conjunction with the Site Emergency Response Manager and ensure an effective response program that includes training of response personnel to minimize and/or control the environmental impact during abnormal conditions, upsets, or environmental occurrences;

7. appoint an Environmental Coordinator to serve in a liaison capacity with Energy Systems Environmental Compliance organization; 


\section{RESPONSIBILTTES (cont.)}

8. assist in formulating and implementing Energy Systems Environmental procedures and standards; develop and implement installation procedures responsive to the Level 1 environmental protection policy, standards, and procedures; and maintain those procedures under current review policy,

9. implement and maintain an environmental protection quality assurance program to provide confidence that all environmental functions are up-to-date and that data generated for pollution control and monitoring activities are accurate and representative;

10. ensure that employees are familiar with established Environmental policies, procedures, standards, and installation procedures related to all aspects of pollution control applicable to the functions for which they are responsible, and provide adequate training to employees to develop the knowledge and skills necessary to fulfill their environmental responsibilities;

11. maintain a program for periodically determining the quantities and concentrations of hazardous, toxic, radioactive, and other materials of interest released and a system for prompt review and reporting of data (all environmental occurrences identified as a result of such review shall be reported through Energy Systems Standard ESS-OP-301, "Occurrence Reporting System");

12. compile data and descriptive material that may be incorporated into the Annual Environmental Monitoring Reports and provide these materials to the report coordinator on a schedule that allows for report publication by the designated date each year,

13. ensure that monitoring and reporting systems are in place, documented, and adequate to define actual or potential pollution of the environment and to meet applicable regulatory requirements;

14. maintain adequate environmental records of significant effluents within the installation as required by Energy Systems, DOE, and regulatory authorities;

15. provide for review of the ES\&H design, acquisition of ES\&H materials and services, and installation of required pollution control equipment as specified in Energy Systems Standard ESS-QA-4.0, "Procurement Document Control";

16. ensure that

2. the required environmental permits and licenses are identified and obtained and associated documents are prepared;

b. permits and licenses obtained meet all permitting and licensing conditions;

c. permits and licenses are renewed on a schedule that allows continuous operation of new and modified pollution sources; and

d. all pertinent permit documentation is maintained as a QA Record;

17. establish and maintain an effective information and communications system to interact with the Energy Systems Environmental Compliance organization and the General Counsel on all significant environmental matters such as reportable spills and/or accidental releases as delineated in Energy Systems Standard ESS-OP-301, "Occurrence Reporting System," regulations interpretation, notices of violation, permits, noncompliances, and environmental insults; 


\section{RESPONSIBILITIES (cont.)}

18. establish and maintain an installation-wide Environmental Assessment and Internal Appraisal Program to ensure compliance with environmental laws and regulations, and maintain a tracking system to ensure follow-up of recommendations (DOE 5482.1B);

19. establish standards for implementing the procedural provisions of the NEPA to demonstrate compliance;

20. review proposed actions, including capital and expense projects, and coordinate the preparation of the appropriate NEPA documentation (DOE Order 5440.1C) and maintain the documentation as a QA Record;

21. review proposed actions for considerations regarding state and federal natural and cultural resources protection statutes [For example, all previously undeveloped land is potentially a natural- or cultural-sensitive area. Wildlife, plant, or historicalarchaeological surveys are required when applicable. Before the destruction of a natural or cultural resource sensitive area is proposed, reasonable project alternatives should be objectively evaluated and documentations submitted to the Energy Systems Environmental Compliance organization and to DOE. In such instances, no further action should be taken until the surveys are reviewed by these organizations and guidance to proceed is received. If guidance is received to proceed, the State Historic Preservation Office must be provided early written notification about the undertaking if historicalarchacological resources are involved. This notification must be submitted to DOE for submittal to and approval by the state. Potential impacts on threatened and endangered species (plant and animal) or historical and archaeological resources must be included in subsequent NEPA documentation.] (National Historic Preservation Act);

22. promptly notify DOE and Energy Systems Environmental Compliance organization of significant environmental compliance issues and related activities bearing on the installation (DOE Order 5400.2); and

23. assign responsibility to resolve the significant environmental compliance issue or related matters and then to implement a coordination process of tracking and documenting that ensures resolution and timely application. (DOE Order 5400.2)

\section{The Environmental Coordinator}

1. routinely coordinates the preparation of environmental reports as required by DOE or Energy Systems management, and

2. ensures that the appropriate level of review, evaluation, and/or concurtence is obtained from personnel within the Environmental Compliance organization before issuance of reports; and

3. Teviews and approves all actions, including new programs and projects, that may bave an environmental impact. 
VII. ADMINISTRATION

The Director, Environmental Compliance organization is responsible for interpretation and administration of this standard.

Approved by: the R/P/ynate

Fred R. Mynatt, Fice President

Compliance, Evaluations, and Policy 


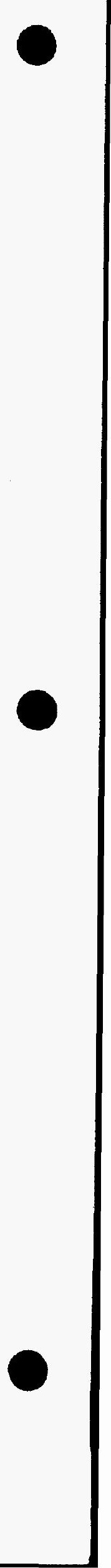




\section{MARTIN MARIETTA ENERGY SYSTEMS, INC. STANDARD}

\section{PURPOSE}

To outline the roles, responsibilities, and lines of communication and coordination needed to develop and maintain an integrated, comprehensive Groundwater Protection Program (GWPP).

\section{REQUIREMENT REFERENCES}

A. DOE Order 5400.1, General Environment Protection Program, 11/09/88

B. DOE Order 5400.4, Comprehensive Environmental Response, Compensation, and Liability Act (CERCLA) Requirements, 10/06/86

C. DOE Order 5400.5, Radiation Protection of the Public and the Environment, 02/08/90

D. DOE Order 5480.4, Environmental, Safety, and Health Protection Standards, 09/23/86

E DOE/OR-1014, Oak Ridge Reservation (ORR) Federal Faciliny Agreement (FFA)

F. Martin Marietta Energy Systems Procedure ESP-IH-161, "Worker Protection in Hazardous Waste Operations and Emergency Response," 05/15/92

G. Tennessee Oversight Agreement (TOA)

H. Kentucky Agreement in Principle

\section{SCOPERIMITATIONS}

This standard applies to all Martin Marietta Energy Systems, Inc., programs and organizations involved in the protection and management of the groundwater resource, particularty, those using groundwater monitoring to investigate and implement environmental compliance, restoration, or corrective action activities.

\section{DEFINITIONS}

A Environmental Compliance Groundwater Protection Program Manager - corporate services staff responsible for the interpretation of requirements, development of standards, and oversight of compliance with environmental requirements and standards.

B. Environmental Compliance orgarization (EC) - the organization reporting to the Vice President of Compliance, Evaluations, and Policy, established to develop corporate environmental policy and to ensure compliance with federal, state, and local environmental regulations and requirements.

C. Environmental Restoration/Waste Management (ERWM) - the organization reporting to the Vice President of ERWM, established to plan and manage the Environmental Restoration (ER), Decontamination and Decommissioning (D\&D), and the Central Waste Management Divisions. 
IV. DEFINITIO: : (iont.)

D. Envir al Sciences Division (ESD) - the division reporting to the Associate Director of Bio: .al and Environmental Sciences for the ... Ridge National Laboratory, which provides te $\quad$ il and scientific support to environmental compliance and restoration programs.

E. Groundwater Program Ofice (GWPO) - organization established by Energy Systems to coordinate and oversee the comprehensive groundwater protection program.

F. Installation Environmental Management Division (EMD) - the organization within each installation delegated the responsibility and authority to ensure environmental compliance.

G. Oak Ridge Hydrology Support Program (ORHSP) - program which provides technical leadership and support for the Energy Systems groundwater program and conducts generic technical studies to provide a basic understanding of groundwater flow and contaminants migration on the Oak Ridge Reservation.

H. Site Groundwater Protection Program (GWPP) Coordinator/Manager - installation position responsible for oversight and/or the implementation of the Groundwater Protection Program Management Plan.

\section{REQUIREMENTS}

A This standard will become effective $\mathbf{3 0}$ days after the approval date.

B. Ensure that the plannir. for the GWPP comprehensively covers all aspects of the protection program, from well siting and development, through well plugging and abandonment.

C. Develop and maintain a GWPP as part of the overall environmental monitoring program plan that identifies and complies with all applicable Department of Energy (DOE), applicable federal, state, and local environmental laws and regulations, and Energy Systems standards and procedures.

1. Provide for the annual site Environmental Reports, a summary of the groundwater monitoring program, which includes a review of the monitoring program describing the number of wells, sampling method, sampling frequency, analyses performed and a summary of results, a summary of the hydrogeology of the site, major aquifers, movement of groundwater, potential sources of groundwater pollution, and uses of groundwater in the vicinity of each site.

2. Provide as elements of the groundwater monitoring program:
a. sampling plan,
i sampling,
c. inalytical, and
d. data management. 


\section{REQUIREMENTS (cont.)}

D. Review the GWPP Management Plan annually and update every 3 years.

E. Monitor groundwater that is, or could be, affected by DOE activities to determine and document the effects of operations on groundwater quality and quantity.

F. Conduct monitoring programs on-site and in the vicinity of DOE facilities to:

1. develop a comprehensive technical characterization of the basic hydrogeology to determine the baseline conditions of groundwater quality and quantity at each installation, or group of installations;

2. provide data to permit the early detection of groundwater pollution or contamination;

3. develop and maintain an integrated, comprehensive groundwater information management and reporting system;

4. identify existing and potential groundwater contamination sources and to maintain surveillance of these sources; and

5. provide data upon which decisions can be made concerning land disposal practices and the management and protection of groundwater resources.

G. Ensure that needed resources are identified, prioritized, budgeted, and obtained to support implementation of this standard.

H. Prepare and disseminate operational procedures and instructions

1. develop and implement consistent procedures and methods for monitoring well installation and development, and

2. revise and implement consistent standards and procedures for groundwater sampling.

I. Maintain current copies of all references outlined in this document, and any other applicable documents which are required to ensure ground water protection personnel access and familiarity with said references.

J. Develop and maintain an Energy Systems Groundwater Program Management Plan to provide consistency in decision-making regarding objectives, priorities, and resource allocations at each installation, which includes:

1. management program for GWPP and remediation, which includes the Safe Drinking Water Act, Resource Conservation and Recovery Act (RCRA), and Comprehensive Environmental Response, Compensation, and Liability Act (CERCLA) actions;

2. strategies for controlling sources of contamination;

3. site ER/D\&D program plans; and

4. the list of operable units. 


\section{REQUIREMENTS (cont.)}

K. Develop trend analysis and predictive capability to identify potential opportunities and threats regarding:

1. health and safety,

2. natural resources and environment, and

3. improved efficiency and management.

L Ensure the preparation and implementation of Quality Assurance Plan(s) to ensure the quality of the comprehensive GWPP, as well as the quality of each installations GWPP, which include the

1. preparation of appropriate organizational charts and written delineation of roles and responsibilities, including explanations of interfaces with other organizations required to meet the Groundwater Protection Program Standard requirements;

2. development and maintenance of management control systems and performance indicators to measure implementation progress and support program modifications;

3. summarize the quality assuring measures taken to ensure the quality of the monitoring data in the overall program, including external and internal laboratory quality control data listing (actual results versus expected data); and

4. ensure that the groundwater to which liquid discharges have been discontinued are managed or decontaminated, in accordance with procedures and requirements in DOE Order 5480.4 and in the 5400 Series.

M. Eliminate unnecessary duplication of effort and monitoring facilities by exploiting commonalities in monitoring requirements among the separate groundwater protection programs at each installation.

N. Refer to the scope, requirements, and responsibilities in Requirement Ref. F. for worker protection.

O. Requirements for the use of private property for groundwater monitoring installations as a part of the GWPP are as follows in the order listed:

1. identify the need for private property use from the sampling and analysis plans, and obtain concurrence on the need from the program or site DOE Contracting Officer Representative;

2. provide a written request to the Energy Systems Property Manager to initiate action to acquire the right to install, maintain, and sample monitoring well(s) on the private-sector property;

3. obtain a copy of the agreement between the DOE-OR and the private-sector owner of the property, which at least should cover (a) management of the licensed site, (b) payment considerations to the property owner, (c) termination of the agreement, and (d) restoration, including funding for same, of the owner's property prior to termination; and 


\section{REQUIREMENTS (cont.)}

4. proceed with the agreed upon plan to install, maintain. and sample groundwater monitoring wells on the property as a part of the GWPP.

P. Records will be maintained in accordance with approved records inventory and disposition schedules and Energy Systems Standard ESS-EH-101, "Environmental, Safety, and Health Activities Required Records."

\section{RESPONSIBILITIES}

A Senior Staff Assistant to the Oak Ridge National Laboratory (ORNL) Director

1. manages and oversees the Energy Systems Groundwater Program Office;

2. communicates progress in program implementation to senior management;

3. assists the GWPO, as necessary, in its interaction with the site GWPP and other Energy Systems management; and

4. serves as the first step in the conflict resolution process.

B. ERWM Project Integration and Administration Director on behalf of the ERWM interests shall:

1. address funding requests to support the Environmental Restoration Program portion of the GWPO activities, and

2. serve as the primary interface on GWPP for all communications and directions between DOEOak Ridge Field Office and Energy Systems Environmental Restoration Programs.

C. Environmental Compliance organization for the GWPO compliance issues shall:

1. develop or assist in the development of standards and procedures, which will be issued under the functional area of environmental protection (EP);

2. provide technical assistance relative to regulatory compliance issues;

3. perform audits of the site GWPP for compliance to the regulations and requirements; and

4. ensure that GWPP concerns are included in the Energy Systems environment, safety, and health strategic planning function.

D. Groundwater Program Office Manager

1. serves as the primary contact for Energy Systems, as delegated by Energy Systems Environmental Compliance organization with DOE. Environmental Protection Agency (EPA), and the states for the overall groundwater protection program and associated technical issues;

2. provides oversight of the implementation of an integrated Energy Systems GWPP; 


\section{RESPONSIBILITIES (cont.)}

3. provides guidance (both technical and administrative) and support via ORHSP on groundwater related issues to ensure appropriate use of committcu resources (e.g., characterization, monitoring, or remediation);

4. establishes and approves budget requirements for the GWPO and assists the site GWPP, as necessary, in developing their budgets.

\section{E. ORHSP Manager}

1. provides technical leadership and support to the GWPP Coordinator/Manager for all components of the Energy Systems site GWPPs;

2. directs the activities of the ORHSP Technical Support staff and the Oak Ridge Reservation Hydrologic and Geologic Studies (ORRHAGS) program;

3. provides leadership in strategic planning and defining work scopes for ORRHAGS activities;

4 ensures that ORRHAGS activities are focused toward site needs and that results are integrated into site programs;

5. serves as primary interface with Energy Systems management, DOE, United States Geological Survey (USGS), and the regulators for work performed on the ORR under an interagency agreement (between DOE and USGS), and on technical issues concerning groundwater; and

6. tracks the GWPO budgets.

F. ORHSP Technical Suppon Staff

1. serves as technical expertise and provides information for the sites groundwater programs relative to geology and hydrology,

2. serves as team member with technical personnel associated with various sire groundwater protection programs,

3. provides timely technical guidance and oversight of an integrated analysis of groundwater data for the sites, and

4. serves as technical communications liaison between the sites and ORRHAGS through the ORHSP Manager.

\section{G. ORRHAGS Manager}

1. provides oversight of ORRHAGS daily activities;

2. assists in performing strategic planning and defining work scopes for future ORRHAGS activities in conjunction with the ORHSP Manager, the Technical Support staff, and the GWPP Coordinators/Managers; 
VI. RESPONSIBILITIES (cont.)

3. prepares ORRHAGS budgets and prioritizes the activities; and

4. serves as mediator with the ORHSP Manager to resolve technical issues at the sites, and when necessary, forms an independent review committee to review conflicts and resolve issues.

\section{H. GWPP Coordinators/ Managers}

1. serve as point of contact for the site, when requested by DOE and delegated by Energy Systems Environmental Compliance organization, to interact with the regulators and with DOE for all hydrogeological activities and issues;

2. coordinates all groundwater activities at the site to ensure that technical issues are addressed comprehensively and consistently among different programs through a strong matrix organization;

3. ensures that applicable DOE Orders, other federal, and state regulations concerning groundwater are implemented at the site;

4. ensures that a consistent set of applicable plans and procedures for groundwater activities are used by all site groundwater programs;

5. ensures integration of technical support, available to the site through ORHSP, into all components of the site groundwater program.

6. notifies site Plant Shift Superintendent of reportable releases; and

7. ensures that the requirements to acquire the use of private property as a part of the groundwater protection program are followed.

\section{REQUIRED RECORDS}

A. Energy Systems and installation environmental compliance division (ECD), safety and health (S\&HD), and environmental restoration division (ERD) organizational charts.

B. Energy Systems and installation ECD, S\&HD and ERD charters of responsibility, authority, and accountability.

C. Installation ECD, S\&HD, and ERD operational procedures and instructions.

D. Energy Systems and installation Groundwater Protection Program Management Plans (GWPPMP).

E. Installation ECD, S\&HD, and ERD documentation of planning priorities and budgets.

F. Installation ECD, S\&HD, and ERD status tracking reports. 
VIII. ADMINISTRA:ION

The Vice Pre sint of Compliance, Evaluations, and Policy is responsible for the administration of this standard. The Director, Environmental Compliance organization is responsible for the maintenance of this standard.

IX. APPENDIX

Performance Objectives and Criteria

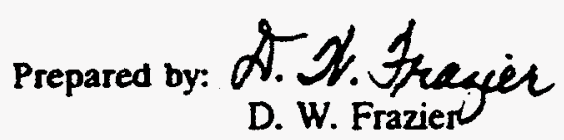

Approved by:

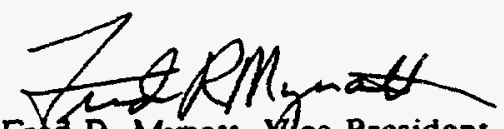
Fred R. Mynat, Vlce President Compliance, Evaluations, and Policy 


\section{APPENDIX}

\section{PERFORMANCE OBJECTIVE}

1. Objective

to develop and maintain an exemplary Energy Systems Groundwater Protection Program by:

a. meeting or exceeding all regulatory requirements;

b. precluding groundwater degradation, given necessary authority and resources; and

c. restoring groundwater to pre-degradation conditions, given necessary authority, technology, and resources.

2. Criteria

a. Develop characterization of hydrogeological systems sufficient to support predictive capability, and

b. Develop capability for trend analysis which, in conjunction with predictive capability, supports detection of potential problems before occurrence.

c. Develop and implement Best Management Practices which;

(1) improve the ability to exceed minimum requirements for protection and restoration; and

(2) improve the consistency and efficiency.

d. Coordinate and refine the above efforts to the extent that the Energy Systems Groundwater Protection Program is recognized as exemplary. 
APPENDIX B

GUIDANCE DOCUMENTS 


\section{GUIDANCE DOCUMENTS}

The following are the applicable guidance documents maintained and utilized by the Y-12 Plant GWPP. They are categorized by the issuing agency or organization and intended to display current guidance actively used by the GWPP. This guidance is not a comprehensive list of all available documents. When the list is updated, noncurrent guidance will be removed.

$\underline{E P A}$

Engineering Support Branch Standard Operating Procedures and Quality Assurance Manual, Region IV, Athens, Georgia, February 1, 1991.

RCRA Groundwater Monitoring Technical Enforcement Guidance Document (TEGD), EPA Office of Solid Waste and Emergency Response (OSWER)-9950.1, September 1986.

Guidelines for Groundwater Classification under the EPA Groundwater Protection Strategy, Office of Groundwater Protection, December 1986.

Underground Storage Tank Corrective Action Technologies, EPA 625/6-87/015, January 1987.

RCRA Facility Investigation (RFI) Guidance, Volumes I - IV, OSWER Directive 9502.00 6C, July 1987.

RCRA Comprehensive Groundwater Monitoring Evaluation Document (RCRA Groundwater Monitoring Systems), RCRA Enforcement Division, March 1988.

Guidance for Conducting Remedial Investigations Under CERCLA, OSWER Directive 9335.3-01, March 1988.

Protecting the Nation's Ground Water: EPA's Strategy for the 1990's, United States EPA, 21Z-0120, 1991, Office of the Administrator, Washington, D.C.

$\underline{\text { State of Tennessee }}$

Policy on Cleanup Levels for Gasoline and Other Petroleum Hydrocarbons (in Soil and Groundwater), TDEC Division of Groundwater Protection, March 18, 1987, Policy UST-001.

Environmental Assessment Report Guidelines, TDEC Division of Underground Storage Tanks, January 1992.

Corrective Action Plan Guidelines, TDEC Division of Underground Storage Tanks, January 1992.

Technical Guidance Documents TGD-002 through TGD-101, TDEC Division of Underground Storage Tanks, January 1992. 


\section{DOE}

Procedures for the Collection and Preservation of Groundwater and Surface Water Samples and for the Installation of Monitoring Wells, GJ/TMC-08 (Second Edition) UC-70A, October 1985.

Environmental Surveillance Plan for the Oak Ridge Reservation, U.S. Department of Energy Oak Ridge Field Office, DOE/OR-1066/R1, May 1995.

Oak Ridge Reservation Site Management Plan for the Environmental Restoration Program, DOE/OR-1001/R3, 1994.

Environmental Regulatory Guidance for Radiological Effluent Monitoring and Environmental Surveillance, DOE/EH-0173T, January 1991.

Martin Marietta Energy Systems, Inc.

Environmental Surveillance Procedures Quality Control Program, ES/ESH/INT-4, 1988. (replaces $\mathrm{ESH} / \mathrm{SUB} / 87 / 21706 / 1)$.

Sampling and Environmental Support Department Operating Procedure: Groundwater Sampling, SESD-TP-8204, June 1995.

Guidelines for Installation of Monitor Wells at the Y-12 Plant, Y/SUB/85-00206C/6, November 1985.

Oak Ridge Y-12 Plant Groundwater Protection Program Standard Practice Procedure, Well Depth Management Procedure G-002. Rev. 1, July 1994.

Oak Ridge Y-12 Plant Groundwater Protection Program, Standard Practice Procedure, Well Plugging and Abandonment, Procedure No. G-003, Rev. 1, October 1994.

Oak Ridge Y-12 Plant Environmental Surveillance Section, Standard Practice Procedure for the Groundwater Protection Program: Well Inspection Procedure, Procedure No. G-001, Rev. 1, July 1994.

Monitor Well Inspection and Maintenance Plan for the Department of Energy Y-12 Plant, Oak Ridge, Tennessee, Y/SUB/91-YP507C/5, July 1991.

Monitor Well Plugging and Abandonment Plan for the Department of Energy Y-12 Plant, Oak Ridge, Tennessee, Y/SUB/91-YP507C/6, October 1991.

Health and Safety Plan for Well Installation and Plugging and Abandonment Activities, Y-12 Plant, Oak Ridge, Tennessee, Y/SUB/92-99928C(Y-11)/1, July 1992. 
Martin Marietta Energy Systems Groundwater Program Management Plan, ORNL/GWPO-001, Draft, February 2, 1993.

Y-12 Plant Groundwater Protection Program-Groundwater Monitoring Program Data Management Plan, Y/SUB/93-TK532C/1, March 1993.

Y-12 Plant Groundwater Protection Program Quality Program Plan, Y/SUB/94-99069C/Y13/1, September 1994. 


\section{DISTRIBUTION}

DEPARTMENT OF ENERGY

J. Donnelly

P. A. Hoffman

HEALTH. SAFETY, ENVIRONMENT, AND ACCOUNTABILITY ORGANIZATION

W. P. Carlton

S. M. Field

C. C. Hill

W. K. Jago

S. B. Jones

L. W. McMahon

J. E. Powell

E. B. Rundle

L. O. Vaughan

File-EMD-RC (4)

ENVIRONMENTAL RESTORATION

PROGRAM

C. S. Haase

H. L. King

File-ERDMC-RC

TENNESSEE DEPARTMENT OF ENVIRONMENT AND CONSERVATION DOE OVERSIGHT DIVISION

H. Crabtree (3)
ENVIRONMENTAL SCIENCES DIVISION

C. T. Rightmire

D. B. Watson

UNIVERSITY OF TENNESSEE

B. W. McMaster

QUALITY AND TECHNICAL SERVICES

L. P. Burnett

J. M. LaBauve

AJA TECHNICAL SERVICES, INC.

J. R. Walker (2)

SCIENCE APPLICATIONS INTERNATIONAL CORPORATION

J. M. Coe

W. P. Kegley

A. K. Lee/DOE-OSTI (2)

Y-12 Central Files 